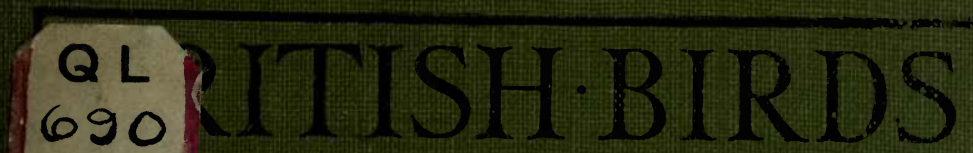

GYKo KIRKMAN,B.A.(OXON)

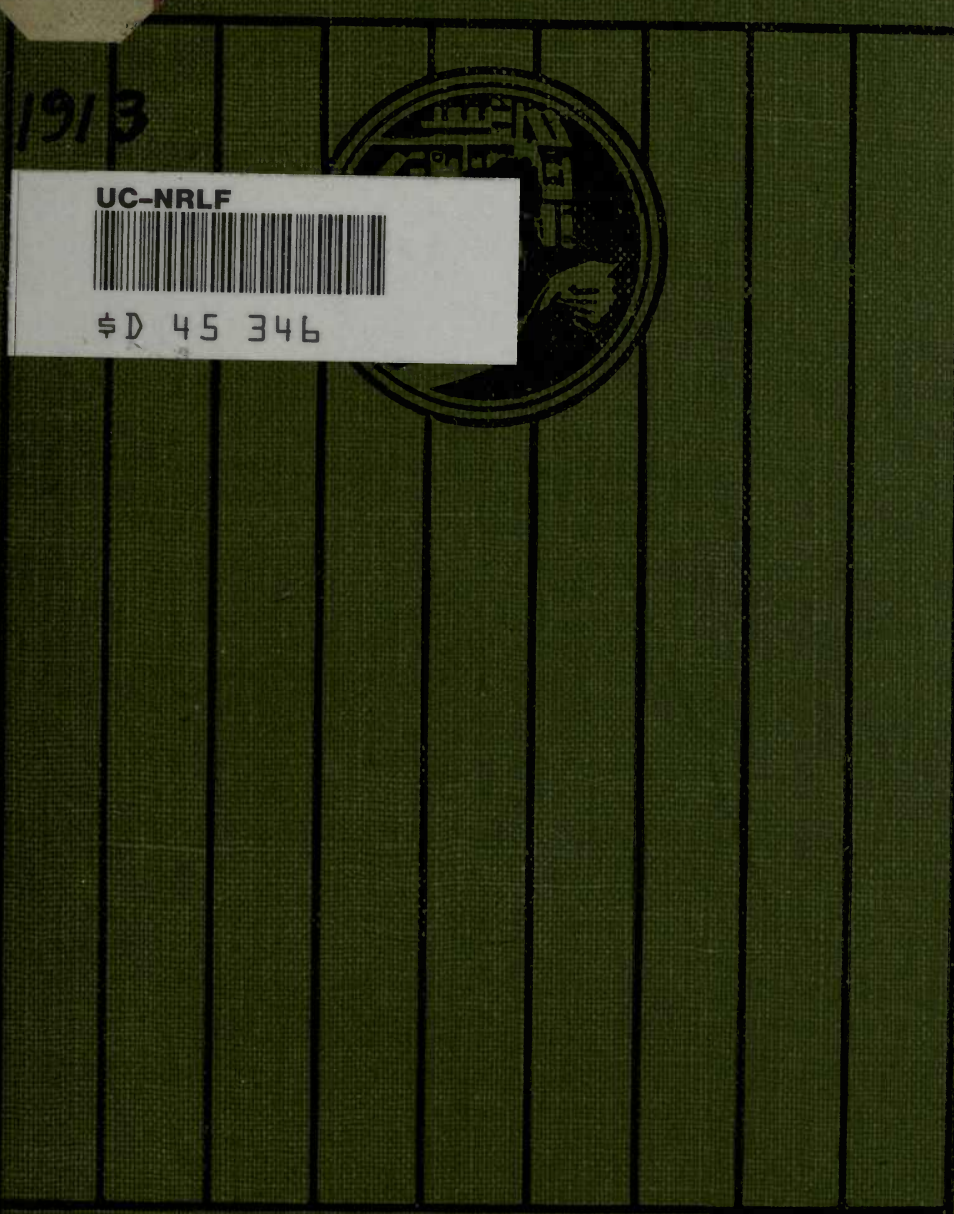

THE·PEOPLE'S·BOOKS 


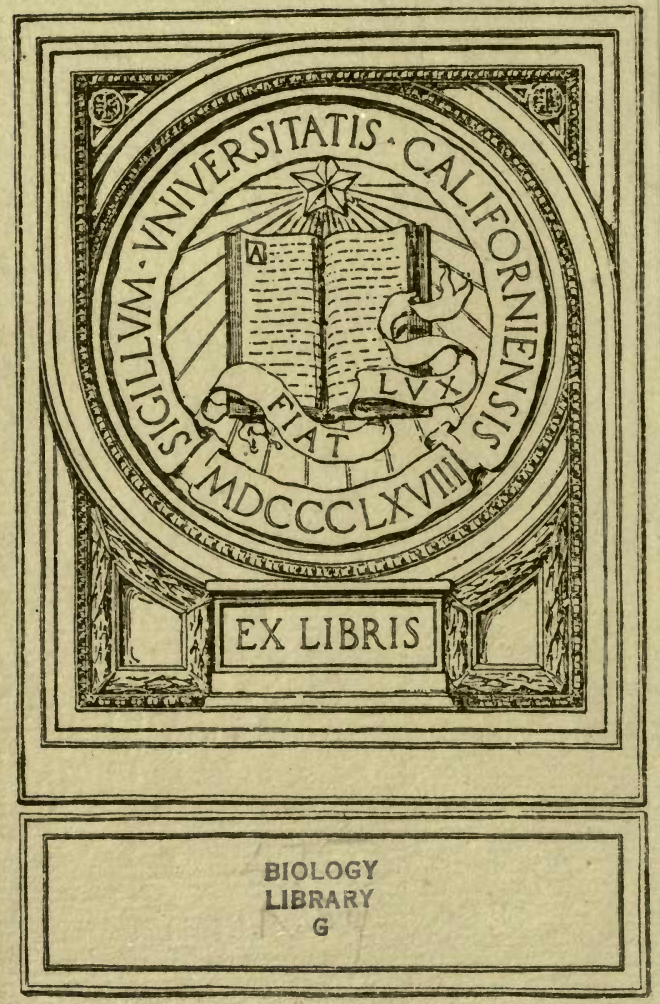





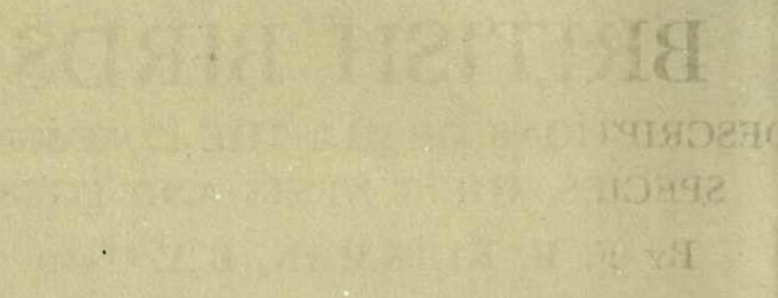




\section{BRITISH BIRDS}

DESGRIPTIONS OF ALL THE COMMONER SPECIES, THEIR NESTS AND EGGS

By F. B. KIRKMAN, B.A. Oxon.

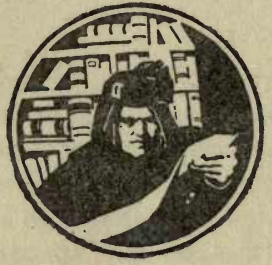

İ̀lustrations By A. W. SEABY

L O N D O N : T. C. \& E. C. J A C K 67 LONG ACRE, W.C., AND EDINBURGH NEW YORK : DODGE PUBLISHING CO. 


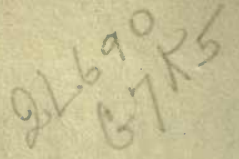

BIOLOGY L.MBRARY C

$$
\begin{aligned}
& \because 3 \div \quad, \because 3 \vdots \div \vdots \vdots
\end{aligned}
$$

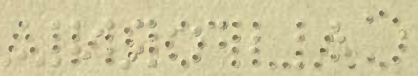

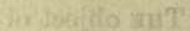
1.iglt Uimoge

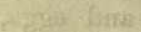
fice. frolderw 


\section{PREFA GE}

THE object of this book is to make as easy as limits of space permit the recognition of all the British species, their nests and eggs, except the rarest. The descriptions have been written with an eye to the requirements of the non-specialist observer, and, if the instructions on p. viii are followed, they should prove adequate for practical purposes.

Descriptions of the female bird and of the young are given only when these differ markedly from the adult male. Likewise seasonal changes of plumage are ignored unless marked enough to make a description necessary for identification. The descriptions and measurements of eggs follow for the most part those of the Rev. F. C. R. Jourdain in the British Bird Book. Complete descriptions of nests have yet to be written, the range of material used by particular species being much greater than the standard works would lead one to suppose. The descriptions here given will, however, suffice for purposes of identification.

The short notes on migration and distribution, and other information as to time of laying, \&c., are introduced solely to aid identification by showing when and where the species and their eggs are to be found. Limitations of space make it obviously impossible to give anything but the strict minimum of information necessary for this purpose.

The scientific nomenclature adopted follows the Rules laid down by the Fifth International Zoological Congress as applied in the Hand-list of British Birds by Hartert, Jourdain, Ticehurst, and Witherby (1912), except in so far as changes in the generic name involve changes in classification. Where this nomenclature differs from that of H. Saunders' Manual, 
(2nd ed.), the latter is also given and placed second. Thus no inconvenience can arise. Where subspecies are clearly recognised trinomials are given, it being obviously incorrect, as a general rule, to give a description as specific which may in part not apply to the whole species but only to one or more of its local forms. ${ }^{1}$

The classification adopted follows generally that of Professor Hans Gadow in Bronn's Thier-Reich: Vögel II.

My best thanks are due to the Rev. F. C. R. Jourdain and to W. Farren of Cambridge for revising the proofs and for valuable suggestions.

All the illustrations are by Mr. A. W. Seaby, except those of the heads of the crow and rook, and one or two others, reproduced from the British Bird Book.

1 Binomial: Corvus corax. Trinomial: Corvus corax corax, the first name being that of the genus, the second of the species, the third of the subspecies, the last being added to distinguish various local forms or races: e.g. the typical Corvus corax corax from Corvus corax hispanus (Spain); Corvus corax varius (Færoes), \&c. 


\section{BIBLIOGRAPHY}

1. Descriptions of Birds, \&c.-Descriptions of the rarer birds, eggs, and nests not given in the present work will be found in the British Bird Book, 4 vols., 1910-13 (ed. F. B. Kirkman), by F. C. R. Jourdain and W. P. Pycraft, and, up to 1899 - since when, however, many species have been added to the British list-in Howard Saunders' Manual of British Birds (2nd ed.). For eggs, F. C. R. Jourdain's Eggs of European Birds, or Dresser's Eggs of the Birds of Europe, may also be consulted.

2. Geographical Distribution and Migration.-There is no recent complete work on Distribution, but short notes up to date will be found both in the British Bird Book, and in the Hand-list of British Birds by Hartert, Jourdain, Ticehurst, and Witherby (1912). On Migration-which, though properly coming under the head of Habits, may conveniently be associated with Distribution-the most recent information is to be found in Eagle Clarke's Studies in Bird Migration, 2 vols., 1912, and the Annual Reports of the British Ornithological Club. Short notes will be found in the two general works above mentioned. A good short work on the general subject is T. A. Coward's Migration of Birds, 1912 (Cambridge Manuals of Science).

3. Habits. - The most recent and complete work on British Birds' habits and instincts is the British Bird Book. Of the older works Yarrell, History of Birds, 4th ed. (revised Newton and Saunders); and Macgillivray, History of Birds, are the best. Seebohm's History is of less value, and Morris's British Birds is not to be recommended. Among the smaller works the best is W. H. Hudson's British Birds. Of monographs, H. F. Howard's British Warblers stands as the model of what.may be achieved. On the general subject of Animal Behaviour, with which the study of the behaviour of Birds must be associated if it is to be of scientific value, the best works are Lloyd Morgan's Animal Behaviour and Habit and Instinct; also Washburn, The Animal Mind, at the end of which a full bibliography is given. From the great mass of general literature there is space to select for mention only the works of W. H. Hudson and E. Selous, and-"lest we forget" - the Natural History of Selborne.

4. Structure and Classification.-For general use W. P. Pycraft's History of Birds and F. E. Beddard's introduction to W. H. Hudson's British Birds will be found adequate. There are also excellent articles in Newton's Dictionary of Birds. More advanced is Beddard's Structure and Classification (1898).

A comprehensive work on the general problems underlying the study of Birds is W. P. Pycraft's History of Birds (1910).

5. Periodicals. - The best for general use are the Zoologist, British Birds (ed. Witherby), and Wild Life (ed. D. English), the latter containing the best extant photographic work. 


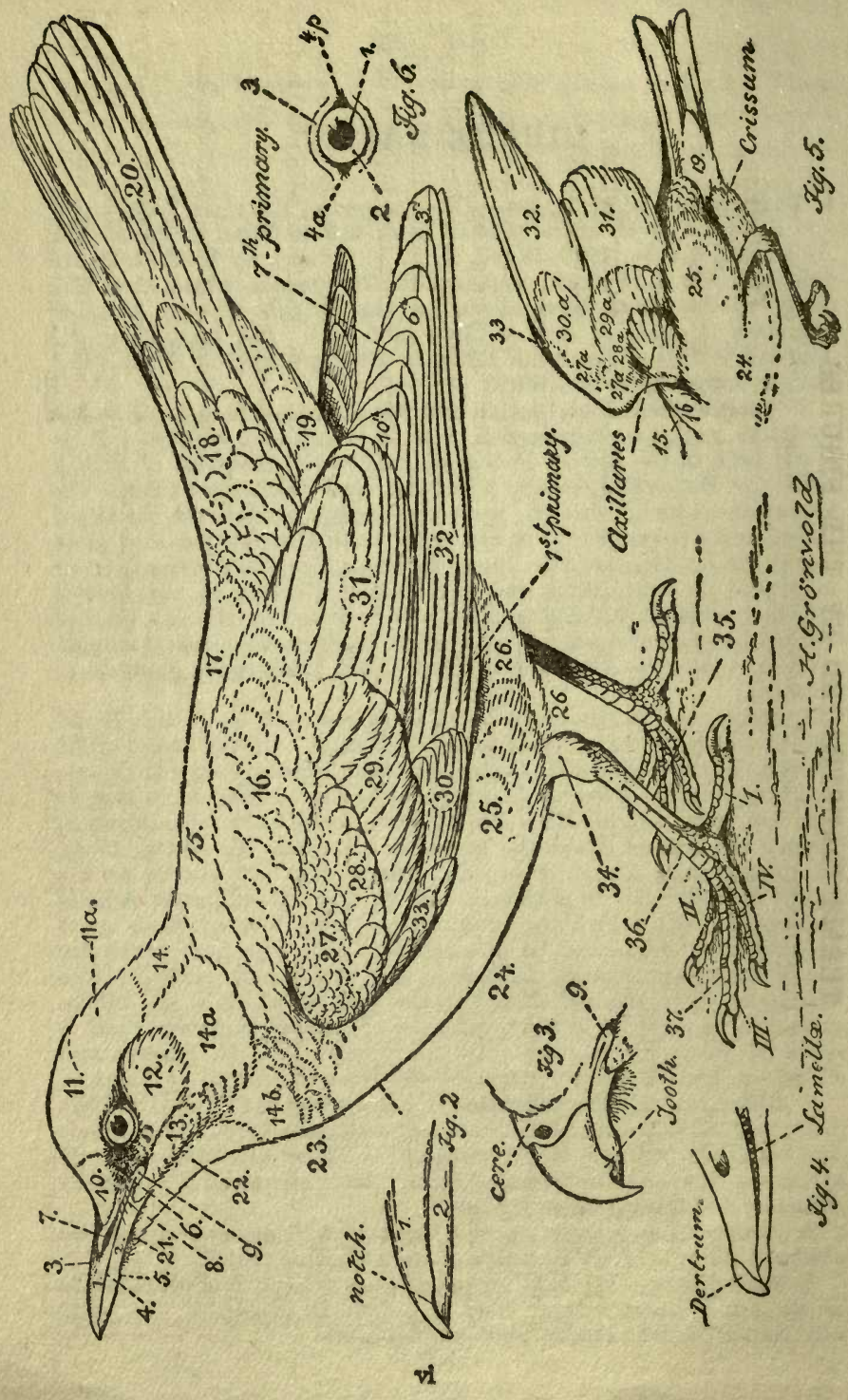




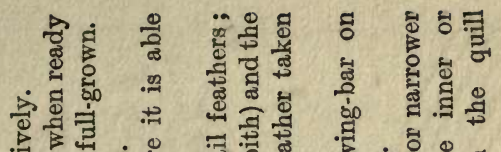

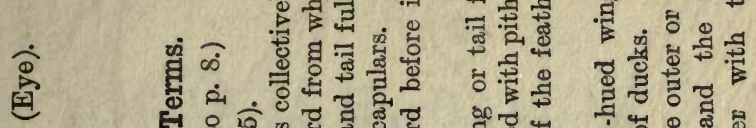

co

स

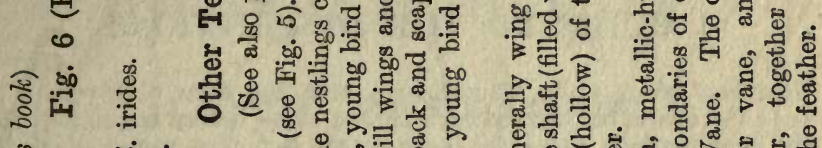

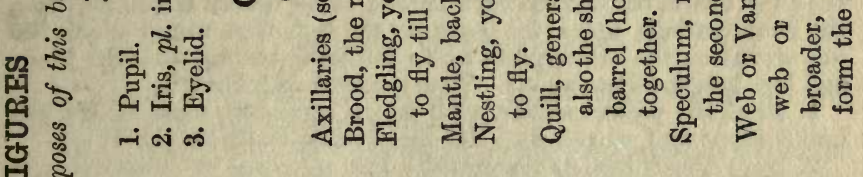

म है है

ㄹ. है

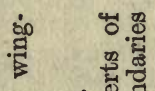

官

욯 $\frac{9}{10}$

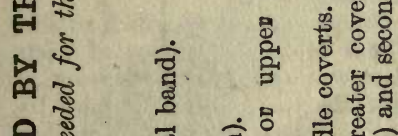

๑

窇

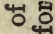

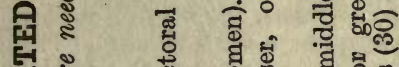

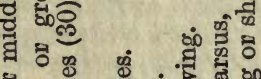

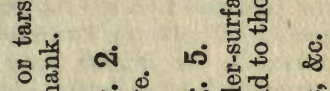

स

.

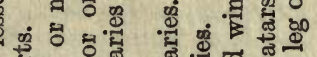

.

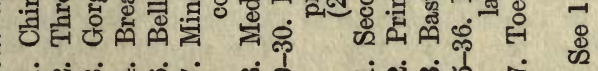

जิ ฟี่

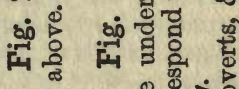

융

ช2

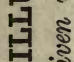

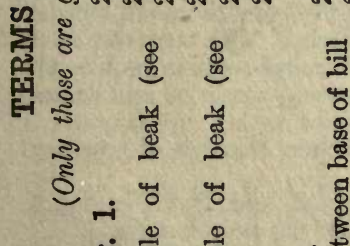

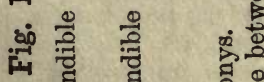

릉

恋

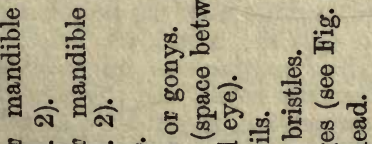

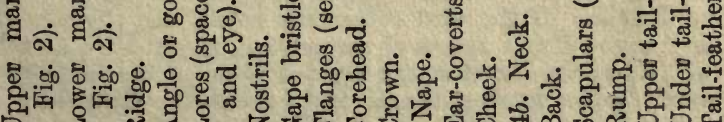
분 है ?口:

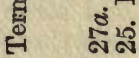

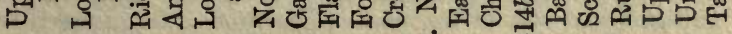
- - ल 


\section{GUIDE TO THE DESCRIPTIONS}

THE best plan, when an unknown bird has been observed, is to note its characteristics always in the same order, beginning with the head, passing down the back to the tail, then round under the tail and along the under-parts up to the beak, ending with the wings and legs (see the Fig., p. vi). Then proceed as follows :

1. Find the picture in the book which resembles most closely the bird's shape and markings. For most small birds see pp. 12-45.

2. Note the length measurement. For purposes of comparison it is useful and easy to remember that the common house-sparrow is 6 inches long, and the rook nearly 20 inches. All measurements are from the tip of the bill to the tip of the tail.

3. See if the bird is in the district at the time of year in which noted. For this see the information given just after the names of each species. The term resident means that the species or subspecies is present in the British Isles all through the year, though it may be represented by different birds at different times, some being winter visitors, others summer visitors, birds of passage or stationary. The summer visitors are those which arrive usually between the end of March and the end of May from winter quarters in Southern Europe and Africa, and depart south generally from September to November. During the latter period the winter visitors are arriving from Iceland, from Northern or Central Continental Europe, or from Greenland and other parts of the Arctic region. The winter visitors depart again north in the spring or early summer. The term bird of passage refers to the summer or winter birds that visit our shores in autumn and spring only on their way to other countries. The term stationary is applied to birds that remain with us throughout the year in the locality in which they breed. Local movements apply to movements from the breeding locality to othen localities within our shores. A local species is one that is found in a certain number of scattered localities within its range.

4. Pass to the description given of the bird, and, if still in doubt, verify, where possible, by the description of the nest and egg.

When unknown nests and eggs are found, the safest is to wait for the bird to return. When waiting the essential is to keep motionless. If the bird cannot be noted, use the size of the nest and egg as a first means of recognition, if you have no other. It is well to remember that the eggs of birds of the same species vary more or less in size, shape, and coloration. The same applies to material and site of the nest. The time of laying also varies, this being later in the more northerly localities. 


\section{BRITISH BIRDS}

\section{ORDER : PASSERIFORMES}

(1) Family: Corvidae-Crows

1. Raven [Corvus corax corax Linnæus]. More or less stationary in hilly or coast districts.

Bird. Length 25 in. Black all over with purplish and blue gloss. Distinguished from the carrion-crow by its larger size

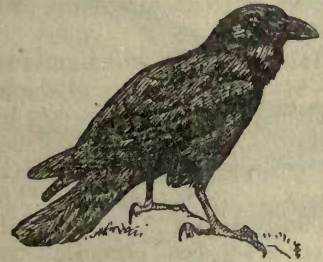

Fig. 1. and the more rounded end of the tail.

Nest. Usually on sea cliffs, also in high trees, rarely in ruins. Outside: sticks, roots, stems, sea-weed, earth. Inside: wool, fur, hair, fibres, grass, \&c.

Eggs. Usually 4-6. Greenish, sometimes blue blotched and flecked with brown to black, and with underlying markings of ash-grey. Av. size, $1.96 \times 1.32$

in. Laying begins in Feb.-March. One brood.

2. Carrion-crow [Corvus corone corone Linnæus]. Resident, except in Ireland and the Isle of Man. Rare N. Scotland.

Bird. Length

19 in. All black with purple and green reflections. End of tail less round than raven's. Bill stouter than rook's. (Fig. 2.)

Nest. Usually in trees or on cliffs. As raven.

Eggs. Usually 4-5. Like raven's, but smaller. Av. size, $1.71 \times 1.18$ in. Laying begins in April. One brood.

3. Hooded-crow, Royston-crow, grey-crow [Corvus cornix 
cornix Linnæus]. More or less stationary in Ireland, Isle of Man, N. Scotland, rarely England. Winter visitor and bird

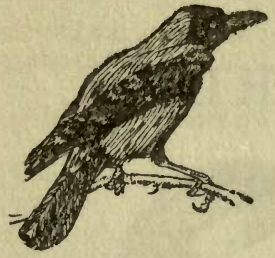

Fig. 3. of passage E. and N. British counties. Bird. Length 19 in. Distinguished from the carrion-crow only by its grey mantle and under-parts. Hybrids between this and the carrion-crow show every gradation between the coloration of the parent species.

Nest. As carrion-crow's.

Eggs. As carrion-crow's, but often greener. Laying begins usually in April. One brood.

4. Rook [Corvus frugilegus frugilegus Linnæus]. Common resident throughout British Isles.

Bird. Length 19 in. Black with bright violet and blue gloss. Distinguished from the carrioncrow by the shape of the bill (Fig. 4) and by the conspicuous bare whitish skin round its base. The statement that the two species can be distinguished by the colour of the bases of the feathers is inexact; these are normally grey in both. The young, up to the second autumn moult, lack the bare face, the base of the bill being feathered.

Nest. The species nests in colonies usually in tree-tops, occasionally on chimney stacks, church spires, in hedges, bushes. Outside: sticks, earth. Inside: moss, leaves, grass, wool, \&c.

Eggs. Usually 3-5. Normally greenish with olive-brown

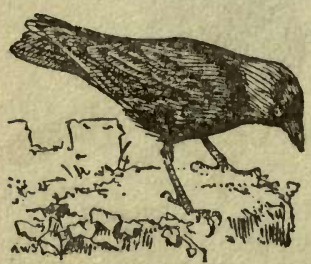

Fig. 5. markings. Size, 1.6 × 1.06 in. Laying begins in March-April. One brood.

5. Jackdaw [Corvus monedula spermologus Vieillot]. See Rook.

Bird. Length 14 in. Black with blue-green or purple gloss. Distinguished from the preceding species, with which it is often seen, by its smaller size, quicker wing-beats, bluewhite iris, and the grey on its nape, neck, and ear-coverts.

Nest. In any convenient hole, usually in buildings, rocks, or 
trees. Occasionally builds open and domed nests in trees. Material : sticks, lined with wool, dry grass, fur, \&c. Species nests in colonies.

Eggs. Usually 4-6. Shades of greenish-blue, marked with brownish-blacks and ash-grey. Av. size, 1.39 $\times 1$ in. Laying begins end April. One brood.

6. Magpie [Pica pica pica (Linnæus); Pica rustica (Scopoli)]. Builds throughout British Isles, where not exterminated. Stationary.

Bird. Length 18 in. Easily recognised by its black and white plumage and long wedge-shaped tail.

Nest. Position : as a rule high up in a tree; also in hedges and bushes. Material: sticks and earth, lined usually with roots, and usually domed with thorny sticks.

Eggs. Generally 5-8. Greenish-blue to greenish-yellow freckled with shades of greyishbrown. Av. size, 1.30 $\times 90$ in. Laying begins in Fig. 6. April. One brood.

7. Jay [Garrulus glandarius rufitergum Hart. and Garrulus glandarius hibernicus Witherby and Hartert]. More or less stationary in wooded districts, the first in Great Britain, the second in Ireland.

Bird. Length 14 in. Distinguished by the reddish-fawn back, conspicuous white rump, and the patch of alternating white, black, and blue on the wing. The under-parts are pale brownish-buff, turning to rufous on the flanks. Tail mostly black. Erectile crest whitish striped with black. Iris blue. The Irish subspecies (G. g. hibernicus) is darker and more rufous than the British (G. g. rufitergum), the most striking differences being the "dark, rufous colouring of the sides of the head, ear-coverts, and under-parts, and the darker crest" (British Birds, Mag. iv. 235).

Nest. Place: bush or tree, usually high up. Material : twigs and stem neatly lined with fine roots, and sometimes other material.

Eggs. Usually 4-6. Pale brownish orgreyish-green, speckledolive-green. Varieties have pinkish or blue ground

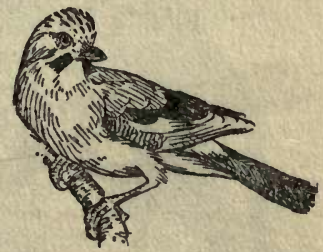

Fig. 7. colour. Av. size, 1.25 $\times .90$ in. Laying begins April-May. One brood.

8. Chough, Red-legged daw [Pyrrhocorax pyrrhocorax (Lin- 
næus); $P$. graculus (L.)]. More or less stationary in certain parts of our S. and W. Coasts and Ireland.

Bird. Length 16 in. Black with blue, violet, and green gloss. Easily distinguished by the red legs and bill, the latter curved. The beak of the young is at first straight, and is coloured various shades of yellow and red till the first autumn moult, when the adult colour is assumed.

Nest. Place: holes and crevices in cliffs, also fissures or ledges in caves. Occasionally holes in old buildings, limekilns, mine shafts. Material : sticks, stems, roots lined with wool, hair, \&c.

Eggs. Usually 3-5. White or cream to brownish marked with reddish-brown shades and underlying lilac blotches and spots. Av. size, $1.55 \times 1 \cdot 10$ in. Laying begins April-May. One brood.

(2) Family: Fringillidoe. Subfamily: Fringillince-Finches

9. Greenfinch, green-linnet [Chloris chloris chloris (Linnæus); Ligurinus chloris (Linnæus)]. Resident and common in most parts.

Bird. Length $5 \frac{1}{2}$ in. Recognised by the yellowish-green of its plumage, the striking yellow on the wing quills and the base of the tail quills, and by the stout bill. The yellow parts are duller in the female, which has also the under-parts chiefly olive-grey and the upper-parts browner. The young have dark brown stripes both on olive-brown upper-parts and the pale yellowish-green under-parts.

Nest. In shrubs, hedges, trees. Material: twigs, moss, roots, wool lined with roots, hair, feathers.

Eggs. Usually 4-6. Whitish or pale greenish-blue ground

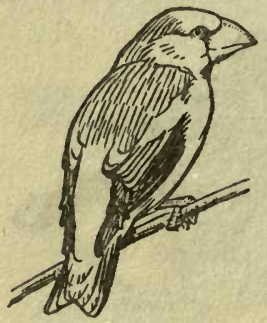

Fig. 8.

primaries (Fig. 9). spotted with reddish-brown and with underlying markings of pale violet or light brown. Unmarked eggs occur. Av. size, $80 \times \cdot 57$ in. Laying begins April-May. Broods 2-4.

10. Hawfinch [Coccothraustes coccothraustes coccothraustes (Linnæus); C. vulgaris Pallas]. Resident in woodland districts. Rare, Ireland.

Bird (Fig. 8). Length 7 in. Recognised by the orange and ruddy browns of its plumage, the huge beak, the horny pads inside it, the black throat and lores, and the shape of the tips of the inner Wing quills black with glossy blue tips. 
The female is distinguished by the ash-grey on the wing. The fledgling has no black on the throat, and has the underparts spotted with dark brown.

Nest. In bushes, trees, hedges. Usually in orchards. Material : twigs, roots, bents, \&c., lined with rootlets, hair, dry grass, and fibre.

Eggs. Usually 4-5. Bluish or greyishgreen boldly streaked and spotted with dark olive-brown and faint markings of purple-grey. Slate-grey and also buff ground colours occur. Av. size,

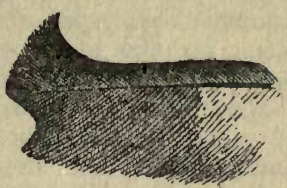

Fig. 9. $.94 \times .68$ in. Laying begins April-May. One brood.

11. Chaffinch [Fringilla coelebs coelebs Linnæus]. Resident in most parts of British Isles.

Bird. Length 6 in. Recognised by the conspicuous white

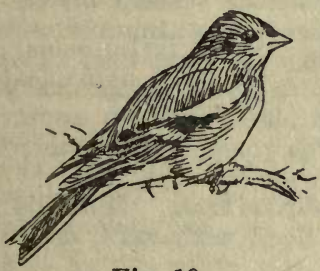

Fig. 10. patches on the wing-coverts, the slateblue crown and nape, light chocolate coloured back, red throat and breast. The hen has the crown and nape greyish-brown, the back olive-brown, the throat and breast whitish-brown with a tinge of orange-red (sienna). The young are much like the hen. Nest. In hedges, bushes, trees. Material: felted moss, wool, \&c., decorated with lichens and lined with hair and feathers. One of the most beautiful nests.

Eggs. Usually 4-6. Pale greenish spotted and streaked with purple-brown. Blue eggs with and without markings occur. Av. size, $\cdot 76 \times 57$ in. Laying begins in April. Broods 1-2.

12. Brambling [Fringilla montifringilla Linnæus]. Winter visitor to most parts, and bird of passage. Accidental in summer.

Bird. Length 6 in. Distinguished by the chestnut throat and breast, white rump conspicuous in flight, and the blueblack feathers of the head and mantle, which in winter have ruddy brown edgings. Belly dull white. The female is brownish-grey mottled with brownish on the head and mantle, lacks the rich chestnut on throat and breast, and is generallyduller.

13. Goldfinch [Carduelis carduelis britannica (Hartert); C. elegans Stephens]. Resident in most parts.

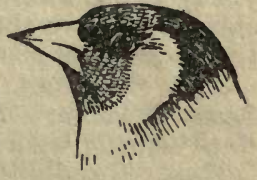

Fig. 11.

Bird (Fig. 11). Length 5 in. Easily recognised by the 
crimson, white, and black of the head and the yellow bar on the wing. Wing and tail quills black with white on the tips. Under-parts mostly grey-brown. Back brown. The young, known as grey-pates or branchers, lack the red, white, and black on the head, which is brownish, and have the upperparts and breast streaked brown.

Nest. Place: trees, shrubs, hedges. Material : neatly built of moss, lichen, roots, \&c., lined usually with hair, wool, down.

Eggs. Usually 4-6. Pale bluish spotted and streaked with deep red-brown, and marked faintly with red-grey. Av. size, $\cdot 67 \times \cdot 50$ in. Laying begins May. Two broods.

14. Siskin [Carduelis spinus (Linnæus)]. Resident in Scotland, Ireland, N. England, N. Wales. Elsewhere winter visitor and bird of passage.

Bird. Length $4 \frac{1}{2}$ in. Recognised by the yellow and green plumage, black crown and chin, and dusky streaks on the back and flanks. For some time after the autumn moult the feathers on the nape and back have ash-grey tips. The hen is greyer and has the crown olive-green with dusky streaks, the chin dull white instead of black, and the underparts all striped, except the belly. The young are still more striated.

Nest. Place: usually high up in coniferous trees. Material : twigs, roots, dry grass, moss, lichen, lined with wool, down, hair, feathers, roots.

Eggs. Usually 4-5. Pale blue marked with red-brown and fainter red-grey. Av. size, $64 \times \cdot 47$ in. Laying begins AprilMay. Two broods.

15. Lesser-redpoll [Linota linaria cabaret (P. L. S. Müller); Linota rufescens (Vieillot)]. Resident in most parts.

Bird. Length $4 \frac{1}{2}$ in. Recognised by its small size, the rosy forehead, crown, breast, and rump, the dusky striated rufousbrown back, the black lores and chin, and the buff wing band. In winter the rose of the breast is obscured by brown. The female has the red on the forehead and crown only. The young lack it altogether, as well as the black on the lores and chin ; they have the upper-parts greyish with dusky striations, the under-parts greyish-white striated on the breast and flanks.

Nest. In trees, also bushes, hedges, sometimes heather, furze, bracken. Material: twigs, stems, moss, wool, \&c., lined usually with down.

Eggs. Usually 4-5. Dull greenish marked with purplishbrown. Av. size, $62 \times \cdot 48$ in. Laying begins April-May. Broods 1-2.

16. Mealy-redpoll [Linota linaria linaria (Linnæus)]. 
Winter visitor and bird of passage chiefly to our East Coast districts.

Bird. Length 5 in. Like the lesser-redpoll, which see, but is larger. Has the rump striated, and lacks the rufous tint in the brown of the back.

17. Twite [Linota flavirostris flavirostris (Linnæus)]. Resident except in S. and E. England, where it is seen only as a winter visitor and bird of passage.

Bird. Length 5 in. Distinguished from the redpolls by having red on the rump only, conspicuous white on the inner primaries, the beak more or less yellow in summer as well as winter, to which fact it owes the name flavirostris, and no black on the chin and lores. Upper-parts brown with paler edgings. Breast and flanks buffish-white, striated brown. The hen and young have no red on the rump, which is striated.

Nest. Place: variable-bushes, heather, on the ground under stones, sods, \&c., in grass, walls, crevices of cliffs, rabbit burrows. Material : roots, grass, stems, moss, twigs, lined with wool, hair, \&c.

Eggs. Usually 4-6. Blue marked with dark red-brown. Av. size, $66 \times 49$ in. Laying begins May. Probably two broods.

18. Linnet, brown-linnet [Linota cannabina cannabina (Linnæus)]. Resident and common in most parts.

Bird. Length $5 \frac{1}{2}$ in. Distinguished from redpolls and twite by the white margins of the tail-feathers. In summer the male has crimson on the crown, forehead, and breast, which in winter turns to grey. The back is chestnut, wing feathers dusky with white outer edges. The hen and young lack the crimson and are more striated.

Nest. Usually in bushes, especially gorse, and in hedges. Material : roots, moss, grass, \&c., lined with hair, wool, feathers, down.

Eggs. Usually 4-6. Shades of pale or whitish-blue marked with purplish-red, and sometimes unmarked. Av. size, $.71 \times 51$ in. Laying begins April-May. Broods usually 2.

19. House-sparrow [Passer domesticus domesticus (Linnæus)]. Resident and common.

Bird. Length 6 in. Distinguished by the white cheek patch, the black gorget, the ash-grey on the crown and rump, the bluish-black beak, and the chestnut of the mantle. The hen has the head and rump brown, mantle pale rufous streaked dusky brown. Buff eye-stripe, under-parts dull buffish-white, beak brown. The young are much like the hen. In winter the grey and black of the cock are obscured by brown, the white by a dull yellowish tinge, and the beak becomes brown. 
Nest. Place : Any hole or crevice in buildings, rocks, stacks, \&c. Also in the branches of trees. Material: straw, hay, \&c., lined usually with feathers. A large untidy structure, domed when in the open, and more or less so when under cover.

Eggs. Usually 4-5. Pale bluish-white marked with varying shades of ash-grey and brown. Often one egg is lighter than the others. There is a reddish variety, also a white. Av. size, $\cdot 86 \times \cdot 61$ in. Laying April-May or earlier. Broods $2-3$ or more.

20. Tree-sparrow, mountain-sparrow [Passer montanus montanus (Linnæus)]. Resident in most

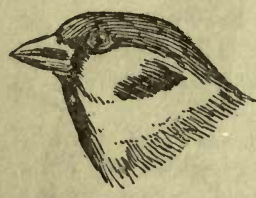

Fig. 12. parts, but rare in W. Scotland and Ireland. Local.

Bird. Length $5 \frac{1}{2}$ in. Much like the house-sparrow, but easily distinguished by its ruddy brown crown and nape, triangular black patch in the white of the cheek, double wing bars of white, and more graceful appearance. The sexes are alike.

Nest. Place: holes in trees, buildings, walls, cliffs, \&c. Material: grass, straw, roots, wool, lined chiefly with feathers.

Eggs. Usually 4-6. Resemble the house-sparrow's, but are smaller, more glossy, and more heavily marked. Often one or two eggs are lighter than the rest. Av. size, $\cdot 77 \times \cdot 55$ in. Laying begins usually May, sometimes April. Broods 2-3.

21. Crossbill [Loxia curvirostra Linnæus]. Two forms: (1) Loxia curvirostra scotica, which is confined to N. Scotland, where it breeds and is stationary except for local movements; (2) the brighter-coloured Loxia curvirostra curvirostra, which is chiefly a winter visitor to most parts, some staying to breed.

Bird. Length $6 \frac{1}{2}$ in. Recognised by the crossed tips of the bill. Male plumage mostly crimson, with

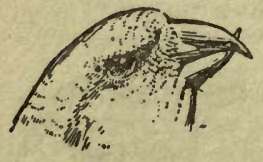

Fig. 13. a touch of orange. Wings and tail brown. Female yellowish-green. The young of both sexes are mostly brown above, dull white below, with dusky striations. The full adult male plumage is not attained till the third or fourth year, a yellowish and mixed yellow and red preceding the final red.

Nest. Place: high up in conifers. Material: platform of larch or fir twigs, on which is placed dry grass, wool, moss, roots, with a lining of finer grasses, sometimes hair. 
Eggs. Usually 3-4. Like large greenfinch's, but with fewer and darker markings. Greenish-white sparsely scrawled or spotted with dark purple-red. Sometimes unmarked, or only faintly so. Av. size, $83 \times \cdot 62$ in. Laying begins usually January-March. Broods 1-2.

22. Bullfinch [Pyrrhula pyrrhula pileata Macgillivray; $P$. europcea Vieillot.] Resident in most parts.

Bird. Length 6 in. Recognised by the black hood, red (rosevermilion) breast, white rump which contrasts with the black tail and grey back and is conspicuous in flight. The hen has the white rump and black head, but differs in having the back brown and the under-part vinous brown. The young lack the black hood, but have the white rump; their whole upper-parts are grey-tinged brown, and the under-parts pale brown.

Nest. In bushes, especially evergreens, and hedges. Material: twigs and moss, lined usually with roots.

Eggs. Usually 4-6. Greenish-blue

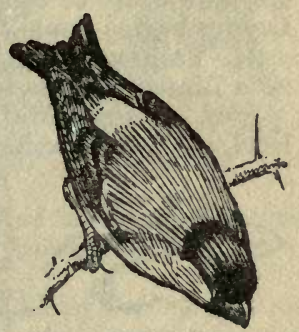

Fig. 14. streaked and spotted, chiefly at the thick end, with purplishbrown, with fainter under-markings. Rare white variety with reddish markings and without markings. Av. size, $77 \times \cdot 57$ in. Laying begins usually May. Broods 1-2.

(3) Family: Fringillida. Subfamily: EmberizinaBuntings

23. Corn-bunting [Emberiza calandra Linnæus; E. milaria Linn.]. Resident in most parts.

Bird. Length 7 in. Distinguished by its heavy build and thick bill. The latter is provided with a palatal knob. General hue ochreous-brown, upper-parts ochreous streaked with dusky brown, under-parts buffish-white streaked with dusky brown on the throat, forebreast, and flanks. Wing-coverts margined with buff, forming a bar. Tail dark brown, edged paler brown. Yellower in autumn and winter. The young resemble the

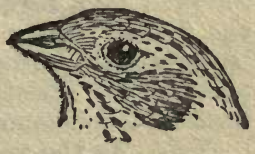

Fig. 15 parents in autumn plumage, with differences of which the chief are a distinctly rufous tint on the throat, and broad 
bright yellow margins to the inner secondaries and tailfeathers.

Nest. Place: long grass, furze, or low bushes on commons or downs. Material: grass, roots, stalks, \&c., lined with finer material, usually grass.

Eggs. Usually 4-6. Rather variable in colour. Usually greyish or yellowish-white with lines, streaks, and spots of dark brown and under-markings of pale violet. Rare varieties are pure white or tinged reddish-brown. Av. size, $95 \times \cdot 69 \mathrm{in}$. Laying begins June-July, sometimes May. Broods 1-2.

24. Yellow-bunting or Yellow-hammer [Emberiza citrinella Linnæus]. Resident and common.

Bird. Length 6:50 in. Distinguished by the lemon-yellow head, neck, and under-parts, and by the chestnut rump. The yellow on the head, neck, and forebreast

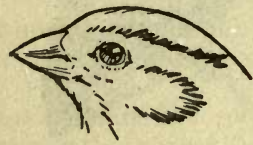

Fig. 16.

brown, streaked black.

is banded with dark greenish-yellow (Fig. 16). The under-parts are streaked with chestnut. Mantle and wing-coverts dull red, striped black. The two outer tail-feathers on each side have white patches. Female and young much less brilliant, and have the crown dull olive-

Nest. Place: usually on or near the ground in hedges, bushes, or banks. Occasionally in hay-stacks. Material: grasses, berits, a little moss or leaves, lined with horse-hair.

Eggs. Usually 3-5. Pale purplish-white scrawled and streaked with dark brown, with a few fainter violet markings. Rare varieties have a white, also a reddish ground. Av. size, $.83 \times \cdot 62$ in. Laying begins April-May. Broods 2-3.

25. Cirl-bunting [Emberiza cirlus Linnæus]. In England and Wales local and more or less stationary. Absent N. England. Very rare in Scotland and Ireland.

Bird. Length $6 \frac{1}{2}$ in. Like the yellow-hammer, but distinguished by the black throat and lores, and the olive-green rump. Below the black of the throat is a bright yellow band, followed by a sage-green band, and reddish-brown stripes on the flanks. Belly yellow. Crown and nape olive-green with black streaks, mantle chestnut. The female has the throat pale yellow striated with black. Distinguished from the female yellow-hammer by the olive-green rump.

Nest. As the yellow-hammer.

Eggs. Usually 3-5. Pale bluish or greenish-white with the markings bolder and darker, as a rule, than those of the yellowhammers, which they sometimes resemble very closely. Av. size, $83 \times \cdot 63$ in. Laying begins in May. Broods 1-2. 
26. Reed-bunting, reed-sparrow [Emberzza shoeniclus shoeniclus (Linnæus)]. Generally resident in marshy localities or reed-beds.

Bird. Length 6 in. Recognised by the black head and throat with intersecting white stripe, and the ash-grey rump tinged and striped with brown. Under-parts white, the flanks striated with brown. Mantle black margined chestnut. Tail dusky with conspicuous white on the outer quills. The hen has the head reddish-brown, striated dusky with yellowish-white stripe below and above the eye. In autumn the male loses the black, which becomes yellowishbrown; the female becomes browner. The young are much like the hen.

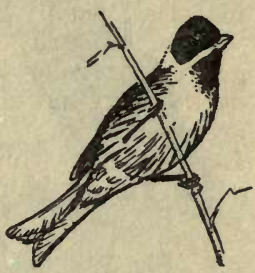

Fig. 17.

Nest. Place: usually near the ground in marshy ground. Material: grasses, bents, lined with finer grasses, hair, or reed-flowers.

Eggs. Usually 4-5. Olive, pale greenish or buff spotted and streaked with black-brown and fainter violet-grey. Av. size, $\cdot 76 \times \cdot 56$ in. Laying begins April. Broods 2-3.

27. Snow-bunting [Plectrophenax nivalis (Linnæus); Passerina nivalis (Linn.)]. Winter visitor chiefly to coast districts. A few breed in the Highlands.

Bird. Length 7 in. Distinguished from all the other buntings by the large amount of white on the wings and their greater length. The male, in the breeding season, is white except on the back, middle tail-quills, and wings, the black on the latter mixed with white. In autumn the upper-parts become mostly chestnut or tawny, and the under-parts more or less tinged with rufous buff. The hen differs chiefly in having the upper-parts greyish-brown flecked with black; in autumn she resembles the male more closely. The young are much like the female.

Nest. Place : usually crevices among boulders on a mountainside; also in sea cliffs in Shetland. Material: usually grass lined with feathers, fine grass, hair.

Eggs. Usually 5-6. White to pale bluish or greenish marked with red-brown and fainter violet. Av. size, $\cdot 86 \times \cdot 63$ in. Laying May-June. One brood.

\section{(4) Family: Alaudida-Larks}

28. Skylark [Alauda arvensis arvensis Linnæus]. Resident and common in most parts. 
Bird. Length 7 in. Upper-parts buffish-brown streaked darker brown. Under-parts pale buff with brown streaks. Wings mostly brown. White edges to

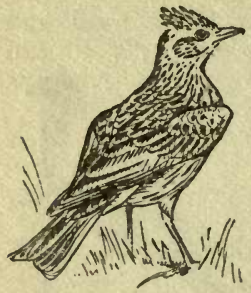

Fig. 18. outer tail-feathers. Erectile crest. Buff stripe over eye. Recognised in flight by kroad buff hinder margin of the pointed wings.

Nest. On the ground, usually in grass or growing crops. Material : grass, bents, lined with finer grasses and generally hair.

Eggs. Usually 3-4. Greyish, greenish, or brownish-white mottled thickly with olivebrown and grey. Av. size, $91 \times \cdot 66$ in. Laying begins April-May. Broods 2-3.

29. Wood-lark [Alauda arborea arborea Linnæus]. Resident in England and Wales. Local.

Bird. Length $5 \frac{1}{2}$ in. In general coloration like the skylark, but distinguished from it chiefly by its smaller size, shorter tail, smaller bill, and the absence of white on the outer tail-feathers.

Nest. On or near ground often sheltered by bracken, heath, or grass. Material: grass, moss, lined with finer grasses, sometimes hair.

Eggs. Usually 4. Dirty white spotted with browns and fainter greys. Av. size, $83 \times \cdot 61$ in. Laying begins MarchApril. Broods 2-3.

(5) Eamily: Motacillide-Wagtails and Pipits

30. Pied-wagtail [Motacilla alba lugubris Temminck]. Resident nearly all parts.

Bird. Length $7 \cdot 30$ in. Both this and the white-wagtail

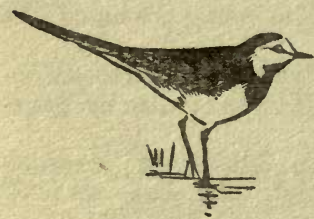

Fig. 19. are easily recognised by the black, white, and grey plumage, and the long black tail with white outer feathers. In summer the cock pied-wagtail is distinguished from the hen by his black upper-parts (except the white forehead), hens being dark grey mottled with black. After the autumn moult the sexes are much alike; both have grey backs and white throats instead of black. The summer black on the upper breast is retained to form a band. The young have olive-brown on the upper-parts and greyish instead of black gorget and crown. 
Nest. Place: usually recesses in walls or banks; also thatches, burrows, old nests, ivy, and elsewhere. Material : moss, roots, twigs, leaves, \&c., lined with grasses, hair, feathers, \&c.

Eggs. Usually 5-6. Greyish-white marked with leaden brown and grey spots. Av. size, $79 \times \cdot 59$ in. Laying begins April-May.

31. White-wagtail [Motacilla alba alba Linnæus]. A summer visitor breeding sparingly chiefly on the south and east of England. Also a bird of passage seen mostly on our western seaboard.

Bird. See pied-wagtail. The male white-wagtail differs in the breeding season from the male pied-wagtail in having the back and rump grey instead of black. Otherwise the two forms are not easily distinguished. The female has grey in the white of the forehead and black of the crown. After the autumn moult both sexes resemble the pied form at the same season, but the white form has grey instead of black tailcoverts.

Nest and Eggs. As pied-wagtail.

32. Grey-wagtail [Motacilla boarula boarula Linnæus ; $M$. melanope Pallas]. Resident in hilly districts, but not common.

Bird. Length $7 \cdot 25$ in. Distinguished from other wagtails by the uniform slate-blue of the upper-parts and longer tail. The male, in breeding plumage, has the throat black, white stripes above and below the eye, sulphur-yellow under-parts, white on the outer tail-feathers. The female differs chiefly in having little or no black on the throat. After the autumn moult both sexes have the throat white and the eye-stripe buff.

Nest. Place: bank, wall, or rocky ledge, usually near streams. Material : moss, twigs, \&c., lined usually with hair.

Eggs. Usually 4-6. Buffish faintly marked with pale brown. Av. size, $\cdot 74 \times 56$ in. Laying begins April-May. Broods 1-2.

33. Yellow-wagtail [Motacilla flava rayi (Bonaparte)]. A summer visitor chiefly to the English and Scottish lowlands.

Bird. Length $6 \cdot 30$ in. Distinguished from the preceding species by the olive-green of the upper-parts and bright yellow eye-stripe, and from the rarer allied blueheadedwagtail [M. flava flava Linnæus], by having the crown yellow instead of blue, the eye-stripe yellow instead of white. The under-parts are bright yellow, wings and tail chiefly dusky brown, the outer tail-feathers white.

Nest. Usually on the ground in meadows or fields, or in a bank. Material : grasses, stems, \&c., lined usually with fine grass and hair. 
Eggs. Usually 5-6. Whitish, mottled often very thickly, with pale brown. Av. size, $\cdot 75 \times \cdot 55$ in. Laying usually begins May. One brood, if not two.

34. Tree-pipit [Anthus trivialis (Linnæus)]. Summer visitor and bird of passage. Rare N. Scotland. Absent Ireland.

Bird. Length 6 in. Resembles the meadow-pipit, with

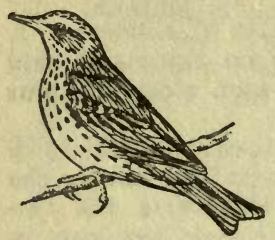

Fig. 20. which it is often confused. It may be distinguished from it by its larger size, by having the claw of the hind toe not so long as the toe itself, and the three outer primaries about equal and longer than the fourth. The meadow-pipit has the claw of the hind toe longer than the toe, and the four outer primaries of equal length. Sexes almost alike. The upperparts brownish, with darker striations, except on the rump. Belly white, rest of under-parts buff with black striations. White on the two outer tail-feathers on each side. Wings chiefly brown and blackish. After the autumn moult both sexes have the whole body tinged with rich buff.

Nest. Place : in woodland on the ground, or in a bank in a tuft of grass or hollow. Material : dry grass, stems, moss, lined chiefly with finer grass.

Eggs. Usually 4-6. Eggs vary greatly in coloration, but those in a nest are of the same type. Ground-colour may be bluish, greenish, pinkish, brownish, or grey, thickly spotted, or blotched and streaked with shades of brown. Av. size, $\cdot 79 \times \cdot 59$ in. Laying begins May. One brood, possibly two.

35. Meadow-pipit, tit-lark [Anthus pratensis (Linnæus)]. Resident throughout the British Isles.

Bird. See tree-pipit. Length $5_{4}^{3}$ in. Sexes alike. Young duller. After the autumn moult the plumage is tinged with buff.

Nest. On pasture-land, marsh, and moorland ; on the ground, or a bank, in the shelter of a tussock, heather, \&c. Material : as tree-pipit.

Eggs. Usually 4-6. Greyish-white thickly marked with brown, so as sometimes to hide the ground colour. Often a black hair streak. Variations with pink and bluish grounds. Av. size, $\cdot 76 \times \cdot 55$ in. Smaller than tree-pipits. Laying begins April-May. Broods 1-2.

36. Rock-pipit [Anthus spinoletta obscurus (Latham)]. Resident on our rocky coasts.

Bird. Length $6 \cdot 25$ in. Distinguished from other pipits- 
except the related subspecies, the Scandinavian rock-pipit (A. spin. littoralis), which is a rare visitor to Great Britain-by the almost complete absence of white on the outer tailfeathers. Sexes alike. Upper-parts olive-brown with darker striations. Under-parts dull white mostly striated dull brown. After the autumn moult the upper-parts have a greenish and the under-parts a yellowish hue.

Nest. Usually in a crevice of a rocky cliff. Material : dry grass, bents, lined with finer grass and hair.

Eggs. Usually 4-5. Greyish to brownish, speckled thickly with shades of brown. Av. size, $83 \times 62$ in. Laying begins April-May. Two broods.

\section{(6) Family: Certhindoe-Tree-creepers}

37. Tree-creeper [Certhia familiaris britannica Ridgway; C. familiaris (Linnæus)]. More or less stationary in most woodland districts.

Bird. Length $5 \cdot 5$ in. Usually seen creeping up and round the trunks of trees. Distinguished by the slender curved beak, long pointed tail-feathers, and silky white under-parts. The upper-parts are mostly brown with paler streaks. Rump rust colour. Wings brown with buffish bar.

Nest. Place: usually behind loose bark on the trunk of a tree, also behind ivy stems or in suitable crevices in walls, outbuildings, \&c. Material: twigs, moss, roots, grasses, \&c., lined with feathers, wool, down, \&c.

Eggs. Usually 5-6. White, marked generally at the large end with reddish spots. Av. size, $\cdot 61 \times \cdot 47$ in. Laying begins April-May.

\section{(7) Family: Troglodytidoe-Wrens}

38. Wren [Troglodytes troglodytes troglodytes (Linnæus); Troglodytes parvulus K. L. Koch]. Resident and common. Two other forms, the St. Kilda wren (T. t. hirtensis Dixon) and the Shetland wren ( $T$. $t$. zetlandicus Hartert) are confined to the islands after which they are named.

Bird. Length $3 \frac{1}{2}$ in. The species is easily recognised by its small body, short tail, and characteristic shape. (Seo Fig. 22.) The common form has the upper-parts gener- 
ally rufous-brown, more or less barred, chiefly on the rump, with dark brown. Bars also on

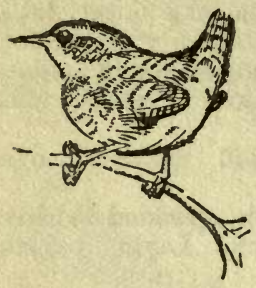

Fig. 22. tail and wings. White spots on the median coverts. Under-parts whitish to brownish, more or less barred with dusky shades on the belly and flanks. Palo stripe above eye. The St. Kilda wren is larger, greyer, and has the bars on the primaries white and dark grey instead of white and dark brown or black. The Shetland wren is darker, especially on the under-parts.

Nest. In almost any convenient recess, in a wall, bank, tree-trunk, \&c., or in a thick bush or creepers. A domed structure with hole at the side and usually well concealed, and matching the site. Material : various-bracken, moss, lichens, leaves, \&c., lined with feathers. Unlined nests are built (as far as is known) by the cock and are not used for eggs unless subsequently lined.

Eggs. Usually 5-8. White, more or less speckled with reddish-brown. Av. size, $\cdot 64 \times \cdot 49$ in. St. Kilda wren's egg, $\cdot 71 \times \cdot 54$ in. Laying begins April-May. Broods 1-2.

\section{(8) Family: Cinclida-Dippers}

39. Dipper or Water-ouzel [Cinclus cinclus britannicus (Tschusi); C.aquaticus Bechstein]. Breeds by quick running rocky streams chiefly in N. and W. England, in Scotland, and Wales. Stationary except for movements to open water in time of

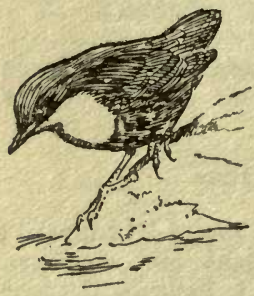

Fig. 23. frost. The black-bellied dipper [C. cinclus cinclus (Linn.)] is an occasional visitor to the east coast. The Irish form [C.c. hibernicus Hartert] is confined to Ireland.

Bird. Length 7 in. The British form is recognised by the dusky plumage contrasting with the white front and by the short tail and wings. Below the white is a patch of chestnut followed by black. Upper-parts mostly lead-grey, but sootybrown on the head. Young differ chiefly in having the under-parts cream colour, mottled grey. The Irish form differs in being darker on the upper-parts and less chestnut on the breast. The black-bellied form has little or no chestnut.

Nest. Place: usually near running water, under a bridge, 
in the bank, under a waterfall, on stumps or boulders, \&c. The nest is generally a rough ball of felted moss with a hole at the side ; it contains a round nest made chiefly of dry grasses lined with leaves.

Eggs. Usually 4-6. White. Av. size, 1.03 $\times 71$ in. Laying usually begins March-April. Broods 2-3.

\section{(9) Family: Turdidae. Subfamily: Turdince-Thrushes}

40. Mistle-thrush, missel-thrush [Turdus viscivorus viscivorus Linnæus]. Resident in most parts.

Bird. Length 10.5 in. Distinguished from the following species by its large size, spotted flanks, and the white spots on the tail-feathers, often conspicuous in flight. Upperparts mostly greyish-brown, under-parts buff turn to white on the belly. Spots on throat and neck fan-shaped, on the breast and flanks oval.

Nest. Place : usually in the fork of a tree. Material: grass, moss, \&c., with an inner cup of mud lined with dry grasses.

Eggs. Usually 4. Usually tawny or greenish-white with reddish-brown and violet markings. Av. size, 1.16 $\times .87$ in. Laying begins March-April, sometimes earlier. Two broods.

41. Song-thrush [Turdus philomelus clarkei Hartert; Turdus musicus Linnæus]. Resident and common. The Continental form [T. ph. philomelus Brehm] is a winter visitor and bird of passage.

Bird. Length 9 in. Recognised by the olive-brown back, fan-shaped black spots on the whitish underparts, except on the flanks, which are striated. Distinguished from the Continental form by the more reddish-brown of the upper-parts and a deeper, somewhat rufous-buff on the breast.

Nest. In bushes, hedges, trees, banks, ivy, rarely on the ground. Material : grass, moss, twigs, \&c., lined with a smooth plaster composed of one or more of the following materials : decayed wood or vegetable matter, mud, dung, chips of straw, or stems.

Eggs. Usually 4-5. Blue with black spots. Av. size, $1 \cdot 11 \times 82$ in. Laying begins Feb.-

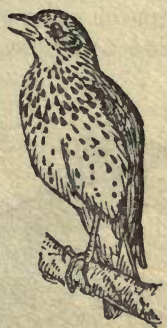

Fig. 24. March. Broods 2-3.

42. Redwing [Turdus musicus Linnæus (1758); Turdus itiacus Linnæus (1766)]. Common winter visitor and bird of passage.

Bird. Length 8.5 in. Distinguished from the preceding forms by the rich red on the flanks-not on the wing as the 
name implies-and in having the breast striated as well as the flanks. Upper-parts olive-brown, a broad white streak over the eye. Ground colour of the under-parts white except for the buff breast and red flanks.

43. Fieldfare, blue-felt [Turdus pilaris Linnæus]. Common winter visitor and bird of passage.

Bird. Length 10 in. Nearly as large as the mistle-thrush, and easily recognised by the chestnut-

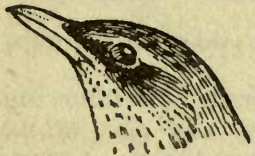

Fig. 25. on the breast and flanks. brown back contrasting with the grey head and neck above and the grey rump below. The latter contrasts with the dark tail, especially in flight. The black lores are noticeable. Throat and upper breast buff, lower breast and belly white. Throat striated black, the striations giving place to various shaped spots

44. Blackbird [Turdus merula merula Linnæus]. Resident nearly everywhere.

Bird. Length 10.5 in. Easily recognised by the black plumage, orange beak, and yellow eye-rim. The female is mostly amber-brown or dusky, varying probably according to age. The throat paler with rufous striations, a rufous tinge on the fore-breast. The young have the upper-parts brown streaked on the crown and mantle with rufous, and the underparts tawny-yellow, more or less barred with black.

Nest. Is found in same positions as that of the songthrush, but more frequently upon the ground; and the outside is built of the same materials. Is lined with mud, upon which is placed a further lining of dry grass.

Eggs. Usually 4-5. Bluish-green or bluish. Spotted or blotched with red-brown and grey.

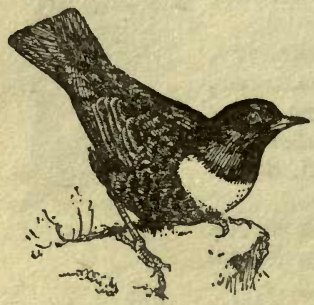

Fig. 26. Av. size, $1.14 \times \cdot 84$ in. Laying begins March-April. Broods 2-3.

45. Ring-ouzel [Turdus torquatus torquatus Linnæus]. Summer visitor to hilly districts and bird of passage. Occasionally remains through winter.

Bird. Length 10.5 in. Recognised by the dusky plumage and the white crescent on the breast. The female is brown, with a narrower and much duller crescent. The young differ chiefly in having the throat feathers white tipped, the forebreast mottled black and brown, and the rest of the under-parts spotted and barred with black and white. 
Nest. On the ground among rocks or heather, rarely in bushes. Material : as blackbird, except that, as might be expected, bracken and heather are more often used for the outside.

Eggs. Usually 4-5. Like the blackbird, but generally with bolder markings. Av. size, $1 \cdot 19 \times 84$ in. Laying begins April-May. Broods 1-2.

46. Wheatear [Enanthe cenanthe cenanthe (Linnæus); Saxicola enanthe ænanthe Linnæus]. Summer visitor and bird of passage. Local. The related subspecies, the Greenland wheatear [0. cenanthe leucorrhoa (Gmelin)], is a bird of passage only.

Bird. Length 6 in. Recognised by the conspicuous white on rump. The male has the upper parts mostly grey, a white stripe passing round the forehead and over each eye, lores and ear-coverts black, wings mostly dark brown, underparts buff except the belly, which is white. The female has the upper-parts and ear-coverts brown, and the underparts all buff. After the autumn moult the male resembles the female. The young differ ehiefly in having the back greyish-brown, and the feathers on the throat and forehead tipped brown so as to form indistinct bars.

Nest. Place: on warrens, downs, stony open country, in rabbit-burrows, under rocks or stones, or any suitable crevice.

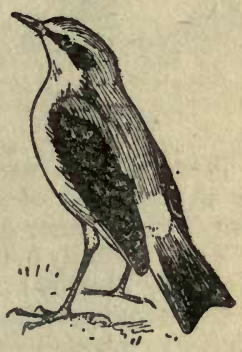

Fig. 27. Material: dry grass lined with hair, fur, wool, \&c. Many pairs may be found nesting near together.

Eggs. Usually 5-6. Pale blue, sometimes speckled with dark red-brown. Av. size, $81 \times \cdot 61$ in. Laying begins AprilMay. Broods 1-2.

47. Whinchat [Saxicola rubetra rubetra (Linnæus); Pratincola rubetra rubetra (Linnæus)]. Summer visitor to most parts and bird of passage. Excoptional in winter. Local.

Bird. Length $5 \frac{1}{2}$ in. Distinguished at all seasons from the stonechat by the white on the basal part of the tail and its slighter build. The male has the upper-parts brown with black markings. The throat and breast is tinged with

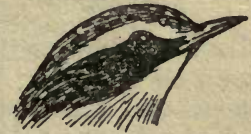

Fig. 28. rufous ; the rest of the under-parts white. A broad white stripe over the eye and two white patches on the wing, the 
smaller sometimes absent. Female duller, with yellow buff eye-stripe. In autumn the male is much like the female.

Nest. Place: usually commons or heaths, on or near the ground in grass, or at the bottom of a bush. Material : grasses, moss, \&c., with lining of finer grass or hair.

Eggs. Usually 5-6. Greonish-blue spotted rust colour. Av. size, $\cdot 73 \times 56$ in. Laying begins in May. Broods 1-2.

48. Stonechat [Saxicola torquata hibernans (Hartert); Pratincola rubicola (Linnæus)]. Resident and local.

Bird. Length $5 \frac{1}{3}$ in. The male has the head and back, chiefly black, contrasted with white patch on the

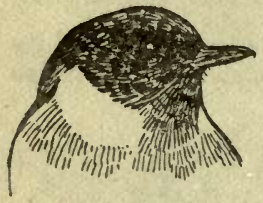

Fig. 29. tail-coverts (not tail itself as whinchat), wing, and neck. Under-parts mostly chestnut and buff. Female differs conspicuously, having the head and upper-parts brown with darker markings, little or no white on the neck, and the under-parts duller. In winter the black of the male becomes brown. The young are much like the female.

Nest. Place: usually commons or heaths, in heather, grass, or at the foot of a bush. Material: moss, grass, \&c., lined usually with finer grass and hair.

Eggs. Usually 5-6. Pale bluish-green with rusty brown spots. Av. size, $\cdot 74 \times \cdot 57$ in. Laying begins March-April. Broods 1-2.

49. Redstart Phonicurus phonicurus phonicurus (Linnæus) ; Ruticilla phonicurus (Linnæus)]. Summer visitor to most woodland districts. Rare in Ireland. Bird of passage.

Bird. Length $5 \frac{1}{2}$ in. The male, in summer, is recognised by

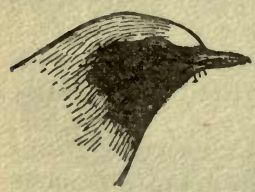

Fig. 30. the white forehead contrasting with the jet black of the sides of the face, the throat, and the neck. Lower rump and tail-coverts chestnut, tail the same but duller. Rest of tho upper-parts slategrey. Breast and flanks chestnut. The female differs in having the upper-parts a uniform brownish-grey. Under-parts dull white, except the forebreast and flanks, which are buff with a rufous tinge. Tail, tail-coverts, and rump as in male. The young resemble female, but have the upper-and under-parts mottled.

Nest. Place : hole in a tree or wall, sometimes on the ground under cover, also in odd places, flower-pots, \&c. Material: dry grasses, rootlets, \&c., lined with horse-hair and feathers.

Eggs. Usually 5-7. Pale blue, occasionally spotted with red-brown. Av. size, $79 \times \cdot 55$ in. Laying begins in May. 
50. Redbreast, robin [Erithacus rubecula melophilus (Hartert)]. Generally resident and common. The autumn and spring birds of passage from and to N. Europe belong to the paler-hued subspecies, $E$. rubecula rubecula.

Bird. Length $5 \frac{3}{4}$ in. Distinguished at all seasons by the orange-red of the throat and breast which is margined bluegrey. Upper-parts olive-brown. Belly white. The fledglings have no red; both their upper- and under-parts are mainly brown, spotted and streaked with buff.

Nest. Place: in banks, or holes in trees and walls, and almost any position that affords some cover. Material : dead leaves, moss, grass, \&c., lined usually with hair and a feather or so.

Eggs. Usually 5-6. Dull white more or less spotted with red. Av. size, $78 \times \cdot 61$ in. Laying begins March-April. Broods 2-3.

51. Nightingale [Luscinia megarhyncha megarhyncha (Brehm); Daulias luscinia (Linnæus)]. A summer visitor to mid and south England and to the eastern borders of Wales. Rarely in the northern counties.

Bird. Length $6 \frac{1}{2}$ in. Recognised by the russet-brown of the unper-parts and the pale chestnut tail. Under-parts white, except the forebreast and flanks, which are greyish-brown. Sexes alike. The young have the chestnut tail, but the upper-parts are rufous with buff spots, and the under-parts chiefly white or buflish-white with darker edgings forming more or less defined bars.

Nest. Place : usually on or near the ground among herbage, in hedge bottoms and undergrowth

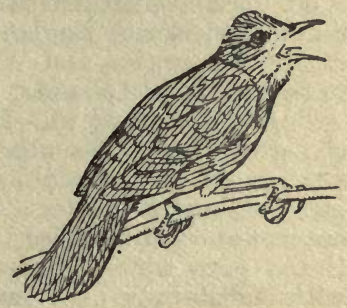

Fig. 31. in woods. Material: usually dead leaves and grass lined with finer material, grasses, leaves, \&c.

Eggs. Usually 4-6. Olive-brown. Rarely blue. "Some clutches show distinct fine brown mottling, tending to form a cap on a blue-green ground" (Jourdain). Av. size, $81 \times \cdot 61$ in. Laying begins in May. One brood.

\section{(10) Family: Turdidoe. Subfamily: Sylviince-Warblers}

52. Whitethroat [Sylvia communis communis Latham; Sylvia cinerea Bechstein]. Widely distributed summer visitor Bird of passage. 
Bird Length $5 \frac{1}{2}$ in. Distinguished by the rust-coloured

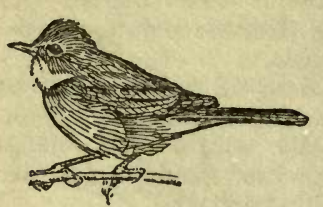

Fig. 32. edgings of the wing-coverts and secondaries. The male, in breeding plumage, has the head ash-grey, upper-parts brown tinged with ochre (clay yellow), the under-parts whitish, except the forebreast which has a rosy tint, and the throat which is pure white. Wing and tail chiefly brown or rust brown, but the outer tail-feathers are mostly white. The female differs chiefly in having the head brown, and being duller. Young are like the female, but browner.

Nest. Usually near the ground, in tangled herbage, small bushes or hedges. Material: grasses and roots loosely put together and lined with horse-hair.

Eggs. Usually 5. Greenish with ochreous or lead-hued markings. Sometimes white or bluish with or without markings, also pink with reddish markings. Av. size, $\cdot 75 \times \cdot 54$ in. Laying begins in May. Usually one brood.

53. Lesser-whitethroat [Sylvia curruca curruca (Linnæus)]. Summer visitor to England and Wales, rare in the south-west, northern counties, and Welsh seaboard. Not proved to breed in Scotland and Ireland. Bird of passage.

Bird. Length $5 \frac{1}{4}$ in. Distinguished from the preceding by the grey head, the absence of chestnut on the wing, and smaller size. Sexes alike, but female duller. Upper-parts mostly greyish-brown. Tail brownish-grey. Outer web of outermost tail-feathers white. Under-parts whitish, with throat pure white, forebreast tinged with pinkish-buff, flanks with buffish-brown. Wings brownish-grey with brown edgings in parts.

Nest. Place: thick bushes, hedges, tangle, usually near ground. Material: stalks, grasses, lined with rootlets, fine grasses, and hair.

Eggs. Usually 5-6. Creamy or white with a zone or cap of brown and grey marking at the big end. Av. size, $\cdot 65 \times \cdot 49$ in. Laying begins in May. One brood, possibly two.

54. Blackcap [Sylvia atricapilla (Linnæus)]. Summer visitor, generally distributed in woodland districts, but local. Scarce in Ireland and $\mathrm{N}$. Scotland. Bird of passage. Winters occasionally in S.W. England.

Bird. Length $5 \frac{3}{4}$ in. Distinguished from our other warblers by the cap-black in the male, brown in the female and young. There is no white in the tail. The upper-parts, wing-coverts, and tail are ash-grey with olive-brown tinge on the back, and 
olive-brown margins to tail-feathers. Wing quills dull grey. Under-parts mostly pale grey.

Nest. In undergrowth, bushes, hedges. Material : chiefly grass, lined with finer grasses and horse-hair.

Eggs. Usually 4-5. Creamy-white marked yellowish-brown and sometimes with dusky spots and streaks. Occasionally salmon-pink with reddish markings. Also white marked and unmarked. Av. size, $\cdot 76 \times \cdot 57$ in. Laying begins in May. Broods 1-2.

55. Garden-warbler [Sylvia borin (Boddaert); Sylvia hortensis (Bechstein)].

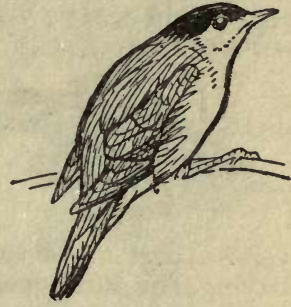

Fig. 33.

Summer visitor generally distributed, but local. Rare in Ireland. Bird of passage.

Bird. Length $5 \frac{3}{4}$ in. Recognised by uniform olive-brown of upper-parts, wing, and tail. Sexes alike. There may be a pale buff stripe over the eye. Under-parts greyish-white with dull buff tinge on throat, forebreast, and flanks.

Nest. Place: bushes in gardens, on wood-edges, in hedges or herbage. Material : grass stalks loosely put together, lined with finer grasses and hair.

Eggs. Usually 5. Like those of blackcap, but glossier and more distinctly marked. Occasionally almost white, with "faint yellowish cloudings or zones of small spots" (Jourdain). Av. size, $\cdot 79 \times 58$ in. Laying begins in May. One brood usual. 56. Dartford-warbler [Sylvia undata dartfordiensis Latham]. Stationary, chiefly in the southern English counties, on gorse commons and heaths.

Bird. Length 5 in. Recognised by the dark brown of the upper-parts and the long fan-shaped tail. The male has the under-parts mostly dark chestnutred. Wing quills sepia-brown. Tail dark brown with a white margin to the outermost feathers. Iris dark red. Female and young paler. With the autumn moult white spots appear on the throat of both sexes, but dis-

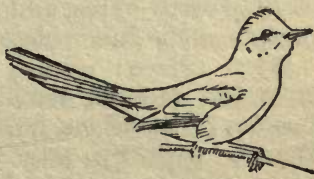

Fig. 34 appear during the winter.

Nest. Place: usually in gorse or rough heather. Material : usually grass stems, \&c., lined with finer grasses and a little hair, wool, or feathers.

Eggs. Usually 4. "Much like the whitethroats, but smaller, less greenish, with a whiter ground and more 
distinct markings of amber-brown and lavender" (Jourdain). Av. size, $\cdot 69 \times \cdot 52$ in. Laying begins March-April. Broods 1-2.

57. Gold-crest [Regulus regulus anglorum Hartert; Regulus cristatus K. L. Koch]. Generally resident in our conifer woods.

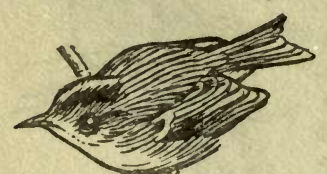

The lighter Continental form, Regulus regulus regulus (Linnæus), is a winter visitor and bird of passage.

Bird. Length $3 \frac{1}{2}$ in. Recognised by the brilliant lemon crest, that of the male having, in addition, a patch (2. of orange-red, and by the olive-green of the upper-parts. The crest is bounded by black. The male has the under-parts dull white, tinged on the throat and flanks with green. The female has the under-parts dull buff. Fig. 35. The young lack the yellow crest.

Nest. Place: usually suspended beneath the end of the bough of some conifer, also in ivy, furze, creepers. Material : green moss and spider webs, sometimes lichens, lined with feathers, also hair or wool.

Eggs. Usually 7-10. White or ochreous, with ochreous or reddish-brown markings. Av, size, $\cdot 53 \times \cdot 40$ in. Laying begins in April. Broods 1-2.

58. Chiffchaff [Phylloscopus collybita collybita (Vieillot); Phylloscopus rufus (Bechstein)]. A summer visitor to our wooded districts. Scarce in Scotland. Also bird of passage. A few winter.

Bird. Length $4 \frac{1}{2}$ in. Distinguished by the blackish legs from the willow-wren, which it resembles. The best means of identification is the song, that of the chiffchaff giving it its name : chiff, chaff, these two notes being repeated as many as ten or more times. The song of the willow-wren, a much commoner species, is a plaintive rippling warble. Upper-parts olive-green. Wing and tail brown, edged olive-green. Underparts mostly dull white. A pale buff stripe over the eye.

Nest. Place: usually not far from large trees, some feet from the ground, occasionally on or near it. Built in mixed tangles of brambles, herbage, and the like ; in bushes, creepers. Domed with opening at the side. Material: usually dead leaves, grass, moss, and other material lined with feathers.

Eggs. Usually 6. White spotted purplish-brown with fainter violet marks. Av. size, $\cdot 61 \times \cdot 47$ in. Laying begins in May. One brood usually.

59. Willow-warbler, also inaptly called willow-wren. [Phylloscopus trochilus trochilus (Linnæus)]. Very common and widely distributed. Summer visitor. Bird of passage. Occasionally winters. 
Bird. Length 4.9 in. Distinguished by the pale brown legs from the chiffchaff, which see.

Nest. Unlike the chiffchaff's it is usually on or near the ground, in grass and other herbage, or in bank sides, and may be found either in woodland or on commons, away from trees. Domed with entrance at the side. Material: grass, moss, leaves, and other material lined with feathers.

Eggs. Usually 6-7. White spotted with reddish-brown. Oceasionally freckled and rarely blotched with

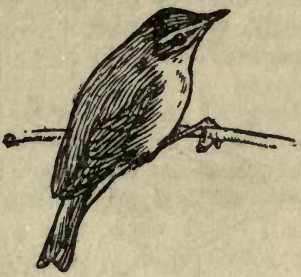

Fig. 36. light chestnut. Underlying marks volet-grey. Av. size, $60 \times 48$ in. Laying begins April-May. Usually one brood.

60. Wood-warbler [Phylloscopus sibilatrix sibilatrix (Bechstein)]. Summer visitor to woodland districts, but local. Scarce in Ireland.

Bird. Length $5 \frac{1}{4}$ in. Distinguished from the chiffchaff and willow-wren by its larger size, longer wings, sulphur-yellow eye-stripe, throat, and flanks, and generally brighter hues. The male, in summer, has the upper-parts yellowish-green. Under-parts whitish, except throat and flanks, which are sulphur-yellow. Tail and wings brown with yellowish-green edgings and whitish tips. Female duller.

Nest. Usually on or near the ground in dead bracken or mixed herbage. Material : bracken, grass, leaves, \&c., with a lining of finer grasses and hair-but not feathers, in which this nest differs from that of the two above. Domed.

Eggs. Usually 6-7. White spotted dark red-brown, inclining to purplish-red. Av. size, $\cdot 62 \times \cdot 34$ in. Laying begins in latter half of May. One brood.

61. Reed-warbler [Acrocephalus streperus streperus (Vieillot)]. Summer visitor to most parts of England and Wales. Absent from Scotland and Ireland.

Bird. Length $5 \frac{1}{4}$ in. Almost impossible to distinguish from the much rarer marsh-warbler. The best means of identification is provided by the nesting-habits, eggs (see below), and by the very superior song of the marsh-warbler, which song has been described as "more silvery, high-pitched, sweet, and varied than that of any other species of warbler with which I am acquainted" (Warde Fowler). "It gave me the impression of the song of a reed-warbler with the voice and execution of a blackcap" (W. Farren). Its alarm-note is "a kind of musical crake" (Warde Fowler). In the reed-warbler the upper-parts are olive-brown inclining to rufous, especially on the rump. 
The marsh-warbler lacks this rufous tinge. Under-parts of both species are greyish or rufous-buff, except the throat and belly which are white. Wing quills and tail greyish-brown with olive-brown margins. Fledglings more rufous.

Nest. The reed-warbler's nest is usually attached to the stems of reeds over water, in which it differs from the marshwarbler's, but, like the latter, may also be found in rank vegetation, osiers and other trees, even at some distance from water. The nest is deep. Material various : grasses, reed-flowers, wool, \&c., lined with the same or feathers and hair. The marshwarbler's nest, placed usually among mixed herbage, meadowsweet, willow-herb, willows, osiers, and the like, is not nearly so deep as the reed-warbler's, or compact. The "main attachment is to two or three, generally two, large stems ; that part of the upper rim of the nest which passes round these stems is stretched and separated from the main rim of the nest. The loops thus formed have been most aptly described by Mr. Warde Fowler as 'basket-handles'"(W. Farren). Material : green stems and the like with a little moss, wool, \&c., lined with hair and rootlets.

Eggs. Those of the reed-warbler number usually 4-5 and are greenish-white, thickly blotched, and marbled with olivebrown and ashy-grey, with occasional blackish spots. Occasionally white. The marsh-warbler's eggs-usually 4-5-have " a bluish or greenish-white ground, boldly blotched with olive and violet-grey, and numerous fine olive specks, as well as a few blackish markings" (Jourdain). Av. size, practically the same for both species : reed-warbler $\cdot 71 \times 53$ in. ; marsh-warbler $\cdot 74 \times \cdot 53$ in. The reed-warbler begins laying in May-June; the marsh-warbler in June. One brood is usual.

62. Marsh - warbler [Acrocephalus palustris (Bechstein)]. Summer visitor to south and mid England. Local, but may be more plentiful than thought.

Bird. Length $5 \frac{1}{4}$ in. See Reed-warbler (No. 61).

Nest. See Reed-warbler (No. 61).

Eggs. See Reed-warbler (No. 61).

63. Sedge-warbler [Acrocepnalus schonobonus (Linnæus); Acrocephalus phragmitis (Bechstein)]. Summer visitor. Rare in north Scotland. Bird of passage.

Bird (Fig. 37). Length 5 in. Recognised by the conspicuous buff eye-stripe, black stripes on the russet head and back, and the markedly rufous or rust-brown rump. Under-parts whitish with buff on neck and forebreast, brownish on flanks. Wings and tail dark brown with paler brown edgings.

Nest. Place : in mixed herbage, bushes, hedges, usually near water or marshy ground. Material: grasses, moss, \&c., lined usually with hair, also with feathers and other soft material. 
Eggs. Usually 5-6. Thickly speckled, or mottled ochreous or yellowish-brown on a paler ground. Not unlike the yellow-wagtail's. Black hair streaks common. There are rare white and pink varieties. Av. length $\cdot 70 \times \cdot 52$ in. Laying begins in May-June. One brood usual.

64. Grasshopper-warbler [Locustella novia nevia (Boddaert)]. Summer visitor to suitable localities-moorland, commons, marsh.

Bird. Length $5 \frac{1}{2}$ in. Distinguished by the slight barring on the tail. It may further be distinguished from other British species by the curious "reeling" note not unlike the continuous chirping of the grasshopper, whence its name.

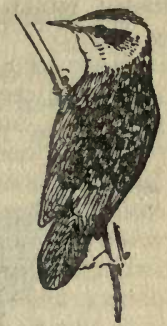

Fig. 37. The upper-parts are reddish-brown with blackbrown markings, more or less in the form of longitudinal lines. Faint eye-stripe. Under-parts pale brownish with a few darker streaks on the breast.

Nest. Place: heather, low down in bushes, undergrowth, and tangled herbage. Material : coarse grass, leaves, moss, \&c., lined with finer grass.

Eggs. Usually 6. Thickly speckled with fine red-brown spots, "which occasionally form a zone, and in rare instances are replaced by bold blotches on a creamy-white ground" (Jourdain). Av. size, $\cdot 69 \times \cdot 53$ in. Laying begins in May. Usually one brood.

\section{(11) Family : Accentoridoe-Accentors}

65. Dunnock or Hedge-sparrow [Accentor modularis occidentalis Hartert; also described as Prunella modularis occidentalis (Hartert)]. Resident throughout our Isles. The Continental and lighter-coloured form [A. m. modularis $]$ is a fairly numerous winter visitor to our east coasts.

Bird. Length $5 \frac{1}{2}$ in. Distinguished by the slate-grey head, neck, andforebreaststreaked with brown. The male has the back streaked with brown on a rufous tinge. Below the slate-grey the breast is dull greyish-white. Flanks palebrownstreaked amberbrown. Wings, quills, and tail dusky brown with paler brown margins. Beak comparatively slender and entirely different from the thick beak of the house-sparrow. Female duller.

Nest. Place: usually in bushes, hedges, creepers, banks. Material : usually twigs, moss, grass, lined with hair, wool, moss, \&c.

Eggs. Usually 4-5. Unspotted blue. Rarely white. Av. size, $\cdot 78 \times \cdot 58$ in. Laying begins in March-April. Broods 2-3. 


\section{(12) Family : Sturnida-Starlings}

66. Starling [Sturnus vulgaris Linnæus]. Resident and common.

Bird. Length $8 \frac{1}{2}$ in. Individuals vary greatly, some having more green about the head, others more purple, a fact which has given rise to the unfounded view that our Isles are

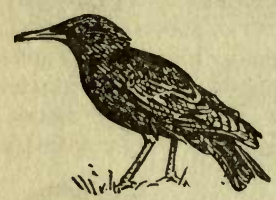

Fig. 38. frequented by two forms, a purple-headed and a green-headed, and to the persistent myth that they are visited by the Siberian-starling, which has rarely been recorded in Europe. Distinguished by the glossy spangled plumage and reddish-brown legs. The male, in summer, has a bright yellow beak, and the plumage mostly a glossy black with metallic reflections of purples and greens and blues. The feathers of the upper-parts are tipped with buff, those of the flanks and belly spotted whitish. The dusky wing quills have rufous-buff margins. Female more spotted and with less metallic gloss. After the autumn moult the metallic hues tend to be obscured and the bill is blackish. The young are easily distinguished from their parents by the uniform greyish-brown of the upperparts, flanks, and forebreast, and the whitish throat and belly.

Nest. In any convenient hole, or what will do duty for such. Material : straw, grass, leaves, \&c., lined usually with a scant lining of feathers, hair, and other material.

Eggs. Usually 5-7. Glossy blue, some almost white. Marked occasionally with traces of reddish spots. Av. size, $1 \cdot 19 \times 84$ in. Laying begins in mid April. One brood, sometimes two.

\section{(13) Family: Parida-Tits}

67. Longtailed-tit [ Eigithalos caudatus roseus (Blyth); Acredula rosea (Blyth)]. Generally distributed and more or less stationary.

Bird. Length $5 \frac{1}{2}$ in Distinguished by the long tail and the black and rose-colour in the plumage.

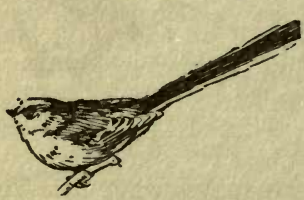

Fig. 39.

The head is mostly white, streaked black. A ring of orange-yellow round the eye. Back black mixed rose-colour. Under-parts white with a few dusky striations on the throat and forebreast, the rest mostly tinged rosy. Wing quills and tail black, the latter with some conspicuous white streaks. The inner secondaries have white margins. The rose-colour is wanting in the young. 
Nest. Place: thick bushes and hedges, also in trees. Material: moss, lichen, cobwebs, hair, wool felted to form a domed nest with the opening at the side near the top. Lined with feathers.

Eggs. Usually 8-12. White spotted light red, sometimes unspotted. Av. size, $55 \times \cdot 43$ in. Laying begins in April. Broods 1-2.

68. Great-tit,ox-eye [Parus major L.]. Resident and generally distributed. Some are winter visitors to our eastern seaboard, but these, owing to the greater size of the beak, have been separated as Parus major major Linnæus. If this distinction is maintained the breeding form becomes Parus major newtoni Prazak. Bird. Length $5 \frac{3}{4}$ in. Distinguished from the other tits by its distinctly larger size and by the broad black band which runs from the black throat down the centre of the under-parts. Head and throat glossy blue-black with a striking white patch on the cheek. Upperparts yellowish-green, passing into bluishgrey on the rump and tail. Outer tailfeathers mostly white. A white spot on the nape. Under-parts mostly sulphur-yellow.

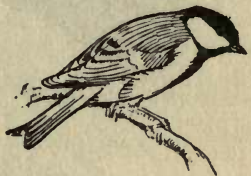

Fig. 40. Wings chiefly greyish-blue and brown with a white bar.

Nest. Place : usually in some kind of hole, also in thickset twigs or old nests of other species. Material : moss, grass, wool, \&c., lined usually with hair or fur.

Eggs. Usually 6-11. White spotted with shades of redbrown; also unspotted. Av. size, $\cdot 70 \times \cdot 53$ in. Laying begins April-May. Usually 1 brood.

69. British coal-tit [Parus ater britannicus Sharpe and Dresser]. Confined, as far as known, to Great Britain, but its winter movements may extend to Ireland.

Bird. Length $4 \frac{1}{4}$ in. Recognised by the conspicuous large white patch on the nape. See also marshtit and willow-tit. Head and throat glossy blue-black with a white patch on each cheek. Upper-parts and wings mostly olive-grey with two white bars on the latter. A rufous tinge on the rump. Under-parts dull white with reddish-buff on the flanks.

Nest. Place : a hole, usually in an old

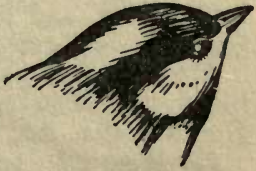

Fig. 41. stump or wall. Material : moss, lined usually with hair, fur, or wool.

Eggs. Usually 7-11. White with red spots. Av. size, $.59 \times \cdot 45$ in. Laying begins April-May. One brood is usual. 
70. Irish coal-tit [Parus ater hibernicus Ogilvio Grant]. Recognised in 1910. Confined to Ireland.

Bird. Resembles preceding, but distinguished by the sulphur-yellow on the cheek patches, nape, breast, and belly.

Nest and Eggs. Like those of the British form, as far as known.

71. Marsh-tit [Parus palustris dresseri Stejneger]. This subspecies is confined to England and Wales, but is absent from Scotland.

Bird. Length $4 \frac{1}{2}$ in. About the size of the coal-tit, but has

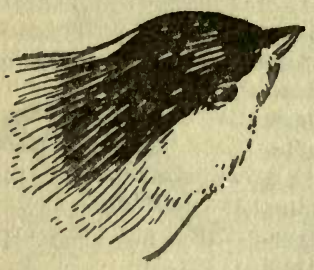

Fig. 42 no white patch on the nape. Head and throat glossy black, except the sides of the head, which are dull white inclining to rufous. Upper-parts mostly olive-brown. Wings and tail mostly ash-brown. Under-parts dull white with buff on the flanks.

Nest. Place: usually in holes in decayed trees. Material: moss lined with fur, hair, or down.

Eggs. Usually 7-8. White spotted with reddish. Av. size, $61 \times \cdot 48$ in. Laying begins April-May. One brood usual.

72. Willow-tit [Parus atricapillus Kleinschmidti (Hellmayr)]. Recognised in 1900. Subspecies confined apparently to Great Britain, but distribution still uncertain. Breeds both in Scotland and England.

Bird. Distinguished from the marsh-tit by lack of gloss in the black of head and neck, and by rounded end of tail, when partly closed, that of the marsh-tit being straight or nearly so. Sexes alike (?). 'The willow-tit's notes are distinct from those of the marsh-tit, but the difference has yet to be clearly defined.

Nest. Place: hole in decayed wood. Said to be excavated by the bird, and in this to be different from the marsh-tit's. Requires verification. Material : said to be scanty.

Eggs. Differ, as far as known, little from those of the marsh-tit. The markings said to be bolder and richer. Number, size, \&c., the same or nearly so.

73. Blue-tit, tom-tit [Parus coruleus obscurus Prazak]. Subspecies confined to the British Isles. Not known to emigrate. The blue-tits that come as winter visitors to our east coast belong no doubt to the Continental form, Parus coruleus ceruleus, which is larger and of brighter coloration.

Bird. Length $4 \frac{1}{3}$ in. The adults readily distinguished by the blue of the cap, tail and wings, the green back, and 
yellow under-parts. Cheeks white. Throat blue-black. White wing bar. Black stripe running backward and forward from the eye corners.

Nest. Place: a hole in a tree or elsewhere. Material: moss and dry grass lined with hair, wool, and feathers.

Eggs. Usually 7-12. White speckled reddish-brown. Sometimes unspotted. Av. size, $\cdot 60 \times \cdot 46$ in. Laying begins AprilMay. Usually one brood.

74. Crested-tit [Parus cristatus scoticus (Prazak)]. The British subspecies is rarely found outside the Spey valley in Scotland.

Bird. Length $4 \frac{1}{2}$ in. Recognised by the crest: the long black, white-tipped feathers of the crown. The male has the sides of the head white enclosing a black more or less semicircular band. The lower side of the white area is bordered with a black band which passes into the black throat. Back, wings, and tail mostly brown or grey. Breast and belly white. Flanks buff. The female has the crest shorter and is duller hued.

Nest. Place: hole or crevice, usually of a decayed pine-tree. Material : moss, lined usually with hair and fur.

Eggs. Usually 5-6. White, boldly marked chestnut-red. Av. size, $63 \times \cdot 49$ in. Laying begins April-May. One brood usual.

\section{(14) Family: Sittida-Nuthatches}

75. Nuthatch [Sitta europcea britannica Hartert; Sitta caesia Wolf]. More or less stationary in the woodland districts of Great Britain, but rare on the western side, and to the north of Cheshire and Yorks.

Bird. Length $5 \frac{3}{4}$ in. Easily distinguished from all British tree-creeping species, and indeed all other British species by its shape (see picture), the blue-grey upper-parts, the rich rufousbuff on the under-parts, and the short tail. The throat and the sides of the head are white, this area being bordered above by a black band running from the corners of each eye backward and forward. The flanks are chestnutred. The outer tail-feathers are patched with white.

Nest. Place: hole or crevice, usually in a tree. When too large, the entrance is plastered round till the hole is just large

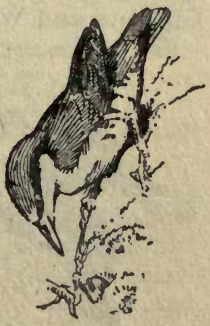

Fig. 43. enough to admit the bird. The lining is composed generally of dry leaves or shredded fir-bark, also dry grass.

Eggs. Usually 5-8. White, spotted and blotched with red- 
brown and a fow underlying violet marks. Unspotted or finely spotted eggs occur. Av. size, $75 \times \cdot 56$ in. Laying begins April-May. One brood usual.

\section{(15) Family : Panuridoe}

76. Bearded-tit [Panurus biarmicus biarmicus (Linnæus)]. Stationary in the Norfolk Broad district, and rarely occurs outside it except in one or two places.

Bird. Length $6 \frac{3}{4}$ in. Recognised at all seasons by the long rounded tail, the deep tawny hue of the upper-parts and flanks, and the small yellow beak. The male has the head bluish-grey with a pointed tuft or "moustache" of black feathers depending from between the eye and the beak. The outer tailfeathers have white ends. Under-parts mostly greyish-white with a rosy tinge. Under tail-coverts black. The female lacks the "moustache" and the black under tail-coverts; her head is tawny, passing below into greyish-white, and her back more or less lined with black.

Nest. Place : reed-bed or marsh, usually among the stems of reed-mace, reed, or sedge. Material: generally reed-blades lined with the flowering heads of the reed, and occasionally feathers.

Eggs. Usually 5-7. White " with streaks, scrawls, or spots of liver brown." Av. size, $\cdot 67 \times \cdot 54$ in. Laying begins in April. Broods 3-4.

\section{(16) Family: Laniidoc-Shrikes}

77. Redbacked-shrike, butcher-bird [Lanius collurio collurio Linnæus]. Summer visitor, chiefly to south and central England and Wales. Bird of passage.

Bird. Length 7 in. Only the adult male has the back red,

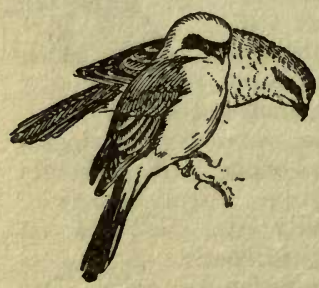

Fig. 44. that of the female being dullbrownishchestnut, and that of the young barred with black on red or reddishgrey. The male has the top of the head and neck grey, and a conspicuous black band running backwards and forwards from the corner of the eyes. The rump is ash-grey. The tail has the centre feathers black, the outer black and white. The under-parts are white with a rosy-buff tint on the breast. The wing quills mostly dark brown. Bill thick and hooked. The female is much less brilliant. The back as above stated. The under-parts are dull 
white with a buff tint on the forebreast and flanks, and are conspicuously barred with semicircular black markings.

Nest. Place: bushes, hedges, tangled growth of brambles, \&c. Material : moss with stalks and other material, lined with rootlets, grasses, wool, hair, down.

Eggs. Usually 5-6. Ground-colour may be white, cream, pink, brownish, or greenish, sometimes bluish, reddish, or bright green. Spotted or blotched usually at the larger end, with brown or reddish and fainter underlying lead tints. Av. size, $\cdot 87 \times \cdot 64$ in. Laying begins in May. One brood.

\section{(17) Family: Muscicapida-Flycatchers}

78. Spotted-fiycatcher [Muscicapa striata striata (Pallas); Muscicapa grisola Linnæus]. Summer visitor, scarce in N. Scotland. Bird of passage (E. Clarke).

Bird. Length 5 in. A small brown spotted bird that perches on the tops of fences, posts, and the like, from which it makes excursions into the air, flitting here and there on quick, graceful pointed wings in pursuit of flies, is almost sure to be the spotted flycatcher. The upper-parts mostly ashbrown with darker brown streaks on the head. Under-parts whitish with dark brown streaks. Gape provided with bristles. The young are conspicuously mottled whitish or buff on the upperparts.

Nest. Place: a large variety of situations, such as beams, holes in walls, haystacks, \&c., where the trunk and some large branch of an old tree meet, rock ledges, deserted nests, creepers, spouts, \&c.

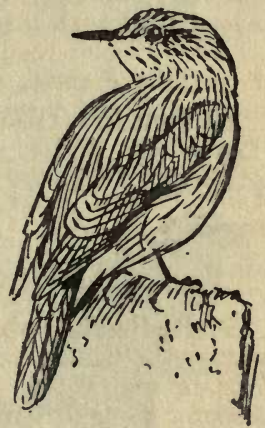

Fig. 45.

Material : grass, rootlets, \&c., lined with hair, wool, and other soft material.

Eggs. Usually 4-5. Generally "Bluish-green at first, which often fades to yellowish-white, sometimes closely freckled with reddish-brown and at other times boldly blotched with chestnut and underlying purplish-brown" (Jourdain). Blue eggs occasional. Av. size, $72 \times \cdot 54$ in. Laying begins in late May or early June. Broods 1-2.

79. Pied-flycatcher [Muscicapa atricapilla Linnæus. By rule of strict priority should be Muscicapa hypoleuca hypoleuca (Pallas)]. Summer visitor to Great Britain, chiefly to N. Wales and N. England. Rare elsewhere. Bird of passage. 
Bird. Length 5 in. The adult male has the upper-parts

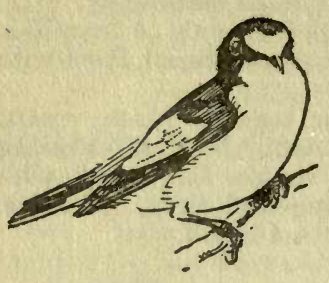

Fig. 46.

black, with greyish rump and white forehead. Under-parts white. Tail all black or black with more or less white on the outer feathers. A white patch on the wing. The female is olive-brown above, including the forehead. Under-parts buffish with white throat and belly. Wing patch whitish or buff. The young are like those of the pied-flycatcher, but may be distinguished by their whitish or buff wing patches.

Nest. Place: generally in a hole in a tree or building. Materials : leaves, moss, grass, \&c., lined with grasses, rootlets, hair, feathers, wool.

Eggs. Usually 6-7. Pale blue. Occasionally speckled red. Av. size, $\cdot 68 \times \cdot 52$ in. Laying begins latter half of May or early June. One brood.

\section{(18) Family: Hirundinido-Swallows and Martins}

80. Swallow [Chelidon rustica rustica (Linnæus); Hirundo rustica Linnæus]. Widely distributed summer visitor. Bird of passage. Bird. Length 7.5 in. Often confused with the house-martin ;

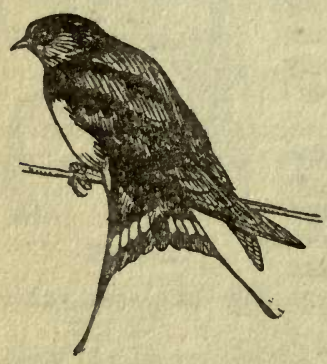

Fig. 47. but the latter is at oncedistinguished, when in flight, from the swallow by the shorter tail and wings and the broad white patch on the lower part of the back, just above the root of the tail. Other marked differences are the chestnut-red on the forehead and throat of the swallow, and the white feathered legs and toes of the house-martin. (See also nest differences.) The swallow's upper plumage is glossy steel blue. The tail dull metallic green, with white spots, and a long streamer on each side. (See Fig.) Under-parts mostly buffish with a blue band bordering the chestnut of the throat. The young are distinguished by the absence of the tail streamers.

Nest. Place: usually under cover in a shed, porch, or cave. Also in chimneys, and all sorts of odd places. Shape either round and of varying depth, or like a half saucer, according to position. Material: mud mixed with grass stems and straw, and lined with grass and feathers. 
Eggs. Usually 5. White with reddish-brown and grey markings. Av. size, $\cdot 77 \times 54$ in. Laying begins in May. Two broods usual.

81. House-martin [Hirundo urbica urbica Linnæus; Chelidon urbica (Linnæus)]. Generally distributed. Summer visitor. More local than swallow. Bird of passage.

Bird. See 80 . Length $5 \frac{1}{3}$ in. Sexes alike. Upper-parts glossy dark blue except the rump, which is white. Wings and tail brown with green reflections. Under-parts all white.

Nest. Place: outside under eaves or under a ledge on a cliff face. Sometimes, like the swallow's, under cover in caves or outbuildings. Built usually against a wall with the top against the eave or ledge, thus forming a closed nest, an entrance hole being left on one side at the top. Material: mud with little admixture of grass, lined mainly with feathers. The species breeds

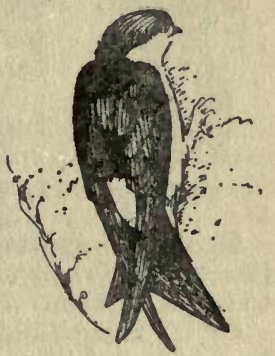

Fig. 48. in colonies.

Eggs. Usually 4-5. White. Av. size, $\cdot 74 \times \cdot 54$ in. Laying begins end May to early June. Broods 2-3.

82. Sand-martin [Riparia riparia riparia (Linnæus); Cotile riparia (Linnæus)]. Summer visitor. Bird of passage. Local.

Bird. Length 4.8 in. Easily distinguished from the two preceding by the pale or sandy brown of the upper-parts. Under-parts white with pale brown on the flanks and across the breast. Wings and tail dark brown.

Nest. Place : in a rounded hole at the end of a burrow, usually $2-3$ feet long, bored by the birds in the face of a sand-pit, cutting, steep bank, or the like. Occasionally in holes in walls, trees and elsewhere. Material : chiefly feathers. The species breeds in colonies.

Eggs. Usually 4-5. White. Av. size, $\cdot 68 \times \cdot 49$ in. Laying begins May. Two broods usual.

\section{ORDER : CORACIIFORMES}

(1) Family: Picida-Woodpeckers

83. Green-woodpecker [Picus viridus pluvius (Hartert); Gecinus viridis (Linnæus)]. Subspecies confined to the British Isles in woodland districts. Rare in Scotland and Ireland. 


\section{BRITISH BIRDS}

Bird. Length $12 \frac{1}{2}$ in. Recognised by the bright green on the upper-parts, greyish-green under-

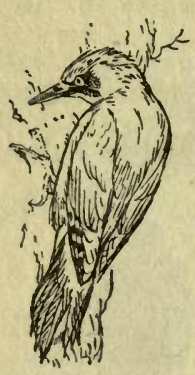

Fig. 49. parts and the rich crimson crown and nape. Toes two before and two behind. The male has a large black patch on the side of the head enclosing a patch of crimson. Rump yellow. Tail black with greenish bars. Outer wing quills chequered white. The female lacks the red in the black cheek patch. The young are distinguished by the barring on the rump and under-parts.

Nest. Place : hole in a tree, almost always bored by the bird. Material : chips of wood. - Eggs. Usually 5-7. Glossy white, sometimes stained by the wood. Av. size, 1:24 x.91 in. Laying begins April-May. One brood.

84. Great spotted-woodpecker [Dryobates major anglicus (Hartert); Dendrocopus major (Linnæus)]. Subspecies confined to Great Britain. Found in woodland districts.

Bird. Length 10 in. Recognised by the black upper-parts, the white patches on the cheek, sides of the neck and scapulars, and the red on the belly and under tail-coverts. Is about $2 \frac{1}{2} \mathrm{in}$. shorter in length than the green-woodpecker. Toes two before and two behind. The male has a band of crimson on the nape which is lacking in the female. Wings black barred with white spots. Under-parts dull buff except for the red. Centre tail-feathers black, others barred dull whitish and black. The young have the crown of the head crimson.

Nest. Place : hole in a tree bored by the bird. Material: chips of dead wood.

Eggs. Usually 5-6. Glossy white, sometimes creamy. Av. size, $1 \cdot 03 \times \cdot 76$. Laying begins May. One brood.

85. Lesser spotted-woodpecker [Dryobates minor comminutus (Hartert): Dendrocopus minor (Linnæus)]. More or less stationary in the woodlands of England and Wales. Exceptional in Scotland and Ireland.

Bird. Length 6 in. More than a third shorter in length than the great spotted form, and has most of the back whitish barred black. Wings as No. 84. Toes two before and two behind. The male has the crown crimson, the female dull whitish. Both have white patchesonthecheeksandsides of neck. Centretail-feathers black, others barred black and white. Under-parts whitish, streaked black on the flanks. Young have more or less crimson on the crown, and buff under-parts with short brown streaks.

Nest. As great spotted-woodpecker, but smaller.

Eggs. Av. size, $73 \times \cdot 56$ in. Otherwise as great spotted form. 
(2) Family: Iynginae-Wrynecks

86. Wryneck [Iynx torquilla torquilla Linnæus]. Summer visitor. Rare except in wooded districts of S.E. England. Bird of passage.

Bird. Length 7 in. Recognised by the variegated pattern of its plumage. The toes, two in front and two behind. The upper-parts are mostly covered with an intricate pattern of grey mixed with brown,

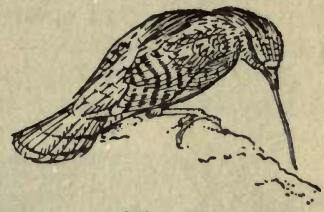

Fig. 50. buff, and whitish, heavily marked with dusky streaks. The erectile crown is barred with chestnut and spotted white. The brown wing quills are spotted with chestnut to form a chess-board pattern. Irregular dusky bars on the greyish tail. Under-parts chiefly buff, deeper on the throat and breast, with dusky bars and $V$-shaped striations. The young lack the heavy dusky streaks on the back.

Nest. Place: usually a hole in a tree not bored by the bird. Also holes in banks. Material : none.

Eggs. Usually 7-8. White. Av. size, $\cdot 80 \times \cdot 60$ in. Laying begins May-June. One brood.

(3) Family: Cypselido-Swifts

87. Swift [Apus apus apus (Linnæus); Cypselus apus (Linnæus)]. Summer visitor, scarce in N. Scotland. Bird of passage (E. Clarke).

Bird. Length 7 in. Differs from the Swallows, Martins, and all other Passerine birds in having all four toes directed forward. It may further be distinguished from the swallow and the martin by its larger size, and the long, narrow, scytheshaped wings equal to the body in length. Plumage sooty black, except the throat, which is dull white. Faint bronze-green gloss on upper side of body.

Nest. Place : under eaves, in holes or crevices of buildings; occasionally in crevices of rocks and quarries. Material:

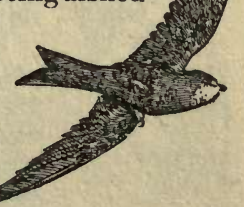
a scanty lining of straw, feathers, and other material picked up by the bird on the wing and cemented together with its saliva.

Eggs. Usually 2-3. White. Av, size, $\cdot 98 \times \cdot 63$ in. Laying begins end May or early June. One brood. 


\section{(4) Family : Caprimulgido-Nightjars}

88. Nightjar, inaptly called goatsucker, nighthawk [Caprimulgus europceus europceus Linnæus]. Summer visitor, generally distributed in open woodlands and waste lands. Bird of passage (E. Clarke).

Bird. Length $10 \frac{1}{2}$ in. Recognised by the flattened head, enormous gape with its bristles, the intricate variegated

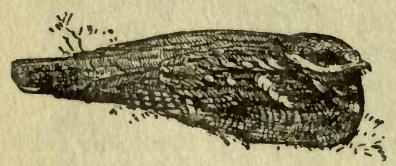

Fig. 52. pattern of its plumage, and its habit of flying in the twilight. The general coloration is ash or silvery-grey closely spotted, streaked and barred with brown, chestnut, and buff. A buff bar across the wing. The male has a white spot on the three outer primaries (2nd, 3rd, 4th) of each wing, and white tips to the two outermost tail-feathers. Otherwise the sexes are alike or nearly so.

Nest. None, though there is some evidence that the bird makes a scrape. The eggs are laid on the ground among dead stick, leaves, \&c., usually among bracken, on waste land or in open woodland.

Eggs. Usually 2. A beautiful creamy- or greyish-white, mottled and streaked with shades of brown and underlying lilac-grey markings. Av. size, $1.24 \times 87$ in. Laying begins end May to early June. One brood, possibly two.

\section{(5) Family: Strigidoc-Owls}

89. Barn-owl, white-owl, screech-owl [Tyto alba alba

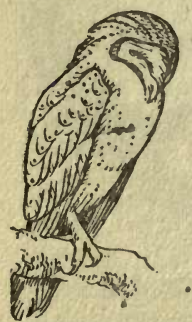

Fig. 53. (Scopoli); Strix flammea]. Found in most parts ; scarce in Wales, N. Scotland, and Ireland. Stationary more or less.

Bird. Length $13 \frac{1}{2}$ in. Distinguished from other British owls by its buff and white coloration. The orange-buff of the upper-parts and wing coverts is delicately patterned with white, brown, and grey. The facial discs are white, with rufous round the eye. Under-parts white with a buff tinge on the breast. Legs covered with white bristle-like feathers.

Nest. None made. The eggs are laid in a crevice or hole in a building, tree, or rocks.

Eggs. Usually 4-6. White without gloss. Av. size, $1.59 \times 1.25$ in. Laying may begin from end March to May. Broods 1-2. 
90. Longeared-owl [Asio otus otus (Linnæus)]. Resident in many woodland districts.

Bird. Length 14 in. Distinguished by the long so-called "ears" ( $1 \frac{1}{2}$ in.). Sexes much alike except that the female is larger. Iris yellow, in which this owl differs from the tawny and barn-owls, which have the irides dark brown. Upper-parts buff with dusky streaks and vermiculations and paler mottlings. Wing and tail quills have dusky bars. Under-parts mainly buff with dusky striations, bars and vermiculations.

Nest. None made. The eggs are usually laid in the deserted nest of Crows or Hawks and other large species, and in squirrels' dreys ; also

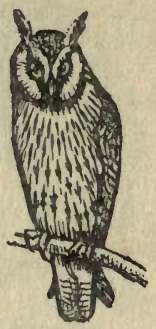

Fig. 54 . on the ground.

Eggs. Usually 3-5. White. Av. size, 1.58 1.62 . Laying begins March-April, exceptionally earlier. One brood usual.

91. Shorteared-owl [Asio flammeus flammeus (Pontoppidan); Asio accipitrinus (Pallas)]. Resident chiefly on the northern moors. Exceptional in Ireland. Also winter visitor and bird of passage.

Bird. Length $14 \frac{1}{2}$ in. Distinguished from the longeared by the short "ears," the absence of bars on the under-parts, which are pale buff streaked with brown, and by its habitat, which is the open country, moors, fens, and the like, that of the longeared being woodland. The female is larger and is somewhat darker. Upper parts buff blotched and streaked with brown. Disc brownet than that of the longeared form. Wings and tail pale buff barred with dark brown. Irides yellow.

Nest. None made, except it be a scratch in the ground. The eggs are laid on the ground in a

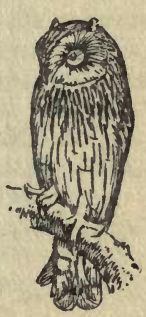

Fig. 55. marsh, on moorland, sand-dunes, or pasture.

Eggs. Usually 4-7. White. Av. size, 1.57 $\times 1.21$. Laying begins March-April, exceptionally earlier. Broods 1-2, sometimes 3.

92. Tawny-owl, brown-owl, wood-owl [Strix aluco aluco Linnæus ; Syrnium aluco (Linnæus)]. Stationary in wooded districts of Great Britain. Absent Ireland.

Bird. Length 15-18 in. Distinguished from the barn-owl by its brownish plumage, and the familiar note or hoot, the $t u$ whit, to-who of Shakespeare. The coloration varies between two distinct types- the grey and the red. The grey type has the body plumage grey streaked, mottled, and more or less 
barred with shades of brown. In the red type the upper parts are reddish-brown with the pattern much as in the grey type, and the under-parts chiefly dull white with dusky streaks and paler bars. The wing quills and tail are brown barred chiefly with shades of the same colour. The tail is tipped with white. The female is the larger.

Nest. None made. The eggs are laid usually in the hole of a tree, also in recesses or crevices in buildings and cliffs, old nests of other species, such as Hawks and Crows, among the exposed roots of trees, and in burrows.

Eggs. Usually 2-4. White. Av. size, 1.84

Fig. 56. $\times 1.52$ in. Laying begins generally in March. - One brood, possibly two occasionally.

93. Little-owl [Athene noctua noctua (Scopoli)]. Resident and on the increase, owing to introduction by Lord Lilford and others. Breeds only in England and Wales. Exceptional vagrant to Scotland and Ireland. Possibly an occasional visitor from the Continent.

Bird. Length 9-91 in., the female the larger. Distinguished from the other British owls described in this book by its much smaller size, and by the white spots on the brown of the upperparts, forming lines and bars. Under-parts mostly dull white with brown streaks. Wing quills and tail brown with paler bars. Irides pale yellow.

Nest. None made. Eggs laid in a hole in a tree, building, or elsewhere, or in a burrow.

Eggs. Usually 4-6. White. Av. size, $1 \cdot 34 \times 1 \cdot 13$. Laid April-May. One brood usual.

(6) Family: Alcedinidoc-Kingfishers

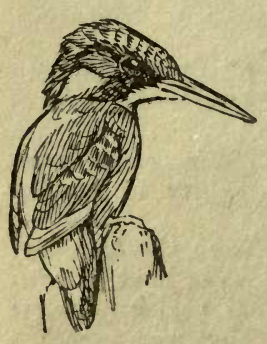

Fig. 57.

94. Kingfisher [Alcedo ispida ispida Linnæus]. Rare in N. Scotland and Ireland. Elsewhere local and more or less stationary.

Bird. Length $7 \frac{1}{2}$ in. Recognised by the prevailing brilliant blues of the back, wings, and tail, by the chestnut of the under-parts and the relatively long black beak. Throat white, bordered above on each side of the neck and head by a blue band, above which is a patch of white passing into a patch of chestnut behind the eye. Female has under mandible red. 
Nest. Usually in a circular chamber at the end of a hole 2-3 ft. long, burrowed in a bank of earth, generally near a stream. Sometimes in holes of walls. Material: fish-bones, accumulated usually after lying in the form of "pellets" disgorged by the birds.

Eggs. Usually 6-7. Glossy white and nearly round. Av. size, $\cdot 89 \times \cdot 73$ in. Laying begins March-April, possibly earlier. Broods 1-2.

\section{ORDER : CUCULIFORMES}

\section{Family: Cuculido-Cuckoos}

95. Cuckoo [Cuculus canorus canorus Linnæus]. Generally distributed. Summer visitor. Bird of passage (E. Clarke).

Bird. Length 14 in. Recognised by the bluish colour of the upper-parts of throat and upper breast, the long dark bluish and whitespotted tail, the white black-barred breast, the toes, two directed forward and two back, and the wellknown note. Wings dark bluish with brownish-black quills. Female smaller, with more or less rufous on

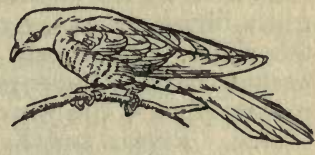

Fig. 58. the forebreast or neck. The young are mainly rufous-brown with dusky bluish bars, and with a more or less white patch on the forehead and nape.

Nest. None made. The hen deposits the eggs in the nest of other species, the hedge-sparrow, Pipits, Wagtails, robin, Warblers, wren, Finches, Redstart, Chats, and many more.

Eggs. Vary greatly in coloration, and sometimes resemble those of the fóster-species. Av. size of $626 \mathrm{eggs}, \cdot 88 \times \cdot 65 \mathrm{in}$. (Rey). The eggs are therefore usually somewhat larger than those laid by the foster-species.

IV. ORDER : CHARADRIIFORMES

(1) Family: Columbida-Pigeons

96. Wood - pigeon, ring-dove, cushat [Columba palumbus palumbus Linnæus]. Resident and generally distributed.

Bird. Length 16 in. Distinguished from other British pigeons by the white patch on the neck and white band across the wing, visible in

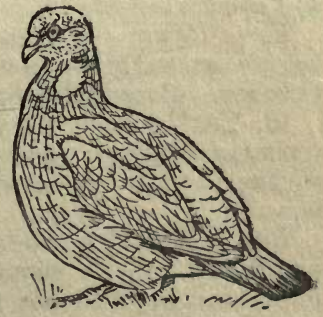

Fig. 59. 
flight. The head, neck, lower back, rump, and tail-coverts bluish-grey. Purple and green reflections on the nape and neck. Mantle and wing-coverts greyish-brown. Tail dusky. Under-parts, vinous-purple on the breast and bluish-grey on the flanks and belly. The young lack the white patch on the neck.

Nest. Place: usually high up in trees or tall hedges. Often in old nests of other species, or in ivy on walls, \&c. Rarely on or near the ground. A flimsy structure of twigs.

Eggs. Usually 2. Glossy white. Av. size, $1.68 \times 1 \cdot 15$ in. Laying begins April or earlier. Broods 2-3.

97. Stock-dove [Columba cenas Linnæus]. Resident and somewhat local.

Bird. Length $13 \frac{1}{2}$ in. Readily distinguished from the preceding form by its smaller size, and from both this and the rock-dove by the absence of white in its plumage. The upperparts bluish or slate-grey. Green and purplish reflections on the sides of the neck. Patches of black on the wing form broken bars. Under-parts : throat and breast vinous purple, rest greyish. The young have no reflections on the neck.

Nest. Place: usually a hole or recess in a tree, building, ground, or old nest. Material : little or none; twigs, leaves, \&c.

Eggs. Usually 2. Creamy-white. Av. size, $1.53 \times 1 \cdot 13$. Laying may begin in March. Broods 2, possibly 3.

98. Rock-dove [Columba livia livia Gmelin]. Frequents sea-cliffs, chiefly on W. coasts and Ireland.

Bird. Length $13 \frac{1}{2} \mathrm{in}$. Distinguished by the large patch of white on the rump. Head, neck and tail dark blue, the tail with a black terminal bar, and with white on the outermost feathers. A patch of metallic green on the neck. Mantle and under-parts blue-grey. Axillaries and under-wing coverts white, conspicuous in flight; those of the stock-dove are grey.

Nest. Place: ledge or crevice in a sea-cave, or crevice in a cliff. Roughly constructed of grasses, roots, heather, sea-weed and other material.

Eggs. Two. White. Av. size, $1.54 \times 1 \cdot 15$ in. Laying begins as early as January-February, and may go on to October. Broods 2-3 or more.

99. Turtle-dove [Turtur turtur turtur (Linnæus); Turtur communis Selby]. Summer visitor. Chiefly in the wooded southern parts of Great Britain; elsewhere scarce. Bird of passage.

Bird. Length 11.25 in. Markedly different from the three preceding both in shape, size, and coloration. It is smaller, more slender, and has the feathers of the wing-coverts and scapulars a rich reddish-brown with black centres, and the 
black side-feathers of the large tail broadly tipped with white. On the side of the neck a conspicuous patch of alternating bars of black and white, which is lacking in the young. Prevailing hue of the head and back bluish-grey with intermixture of dull rufous or buff margins. Under-parts pale vinous purple passing to white on the belly.

Nest. Place: tree, bush, or tall hedge. Flimsy structure of twigs.

Fggs. Two. Creamy-white. Av, size, $1 \cdot 18 \times \cdot 88$ in. Laying begins end of May to early June. Broods 1-2.

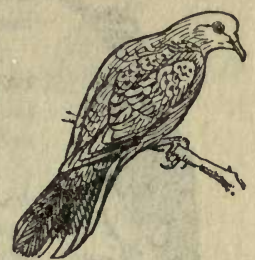

Fig. 60 .

(2) Family: Alcido-Auks

100. Razorbill [Alca torda Linnæus]. Salt-water species present throughout the year, and breeding on our sea-cliffs.

Bird. Length 17 in. Distinguished at once from the guille-

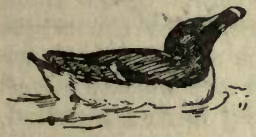

Fig. 61. mot by the deep curved and grooved beak withits conspicuous narrow white band (see Fig.), by the darker upper-parts and the stouter neck. Sexes alike. In the breeding season the upper-parts are mostly black with greenish gloss. A white bar on the wing, and a white line from beak to eye. Throat and fore-neck brown, rest of under-parts white. Outside the breeding season the throat, fore-neck, and part of the sides of the head are white.

Nest. None made. The egg is laid on the bare rock, preferably in a crevice or under a ledge ( $c f$. the guillemot); occasionally under boulders. Species breeds in colonies, often with guillemots.

Egg. One. Less pear-shaped than the guillemots. Ground colour white, buff, brownish, reddish, and occasionally bluishgreen, blotched, spotted, and streaked with dark brown or black. Av. size, $2.95 \times 1.86$. Laying begins in May. One chick reared.

101. Guillemot [Uria troille troille (Linnæus)]. As razorbill, and often breeds on the same cliffs.

Bird. Length $18 \mathrm{in}$. At once distinguished from the razorbill by its much more slender and longer beak and slenderer neck and paler upper-parts. Sexes alike. Many individuals have a white circle round the eye with a backward white crease, and are known as "bridled" or "ringed." In summer the upper-parts, head, and neck are slaty-grey, turning to smoke brown as the season advances. The under-parts are mostly 
white. A white bar on the wing. In winter the throat

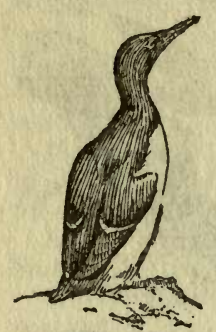

Fig. 62. and part of the sides of the neck and head become white.

Nest. None made. The egg is laid on the bare rock on open ledges, or tops of stacks. (See razorbill, No. 100.) Species breeds in colonies.

Egg. One. Pear-shaped. Av. size, 3.04 × 1.94 in. Coloration very varied. Ground colour may be various shades of white, yellow, brown, blue, green, or pink, spotted, blotched and lined with reds, browns, blacks, yellows, greens. Some eggs unmarked. Laying begins May, later than with the razorbill. One chick reared.

102. Black-guillemot [Cepphus grylle grylle (Linnæus)]. Salt-water species more or less stationary on the coasts of Scotland, Ireland, and the Isle of Man. Exceptional further south.

Bird. Length 11 in. Distinguished by the vermilion-red of the legs and the large white patch on the wings. Sexes alike. Plumage, black with green reflections, except for the white areas both on the upper and under-side of the wing. In winter the feathers of the upper-parts of the body are mostly edged with white. Under-parts white. The young have a mottled, barred white-and-black appearance.

Nest. None made. The eggs are laid on the bare rock, usually under boulders at the foot of cliffs or in crevices in the cliff, exceptionally in holes of ruins. Species nests singly or in relatively small colonies.

Eggs. Usually 2. Whitish, marked with dark brown and ash-grey. The ground colour may have a tinge of bluish-green. Av. size, $2.32 \times 1.56$ in. Laying begins in May-June. One brood. 103. Little-auk [Alle alle (Linnæus); Mergulus alle (Linnæus)]. Irregular winter visitor, mostly off our north and east coasts.

Bird. Length $7 \frac{1}{2}$ in. Recognised by its small size. In winter the upper-parts are mostly black, with white margins to the upper scapulars and secondaries, and a white spot over the eye. The under-parts are white, including the sides of the neck, except for a more or less incomplete collar of black. Immature birds lack the white spot over the eye. In spring the throat and neck become black.

104. Puffin [Fratercula arctica arctica (Linnæus)]. Sea-water species breeding on all the coasts of the British Isles. Uncommon near shore in winter.

Bird. Length 13 in. Recognised by the large grooved and 
strikingly coloured beak, and the deep orange legs. Sexes alike. In summer the fore-part of the beak is red, the hinder-part slateblue, the two areas being divided by a yellow line. In winter the yellow line and the slate-blue horny plate disappear, together with the creamcoloured fillet at the base of the bill, the orange-yellow rosette at the gape, and the slate-coloured appendages above and below the eye. No noticeable seasonal change in the

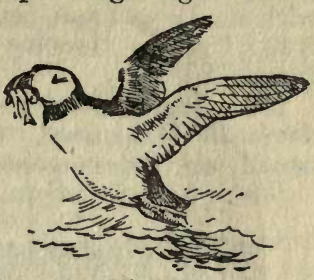

Fig. 63. plumage. Upper-parts black. Sides of the head pale greyish. Under-parts white, except black band round under the throat. The young have the beak much smaller.

Nest. In a burrow in the soil on the top or sides of an isle or cliff, also under boulders and in crevices. Material: usually a little grass and feathers. Species breeds in colonies.

Eggs. One. Dirty white, with more or less faintly marked shades of brown or violet. Av. size, $2.39 \times 1 \cdot 67$. Laying begins in May. One brood.

(3) Family: Laridce. (a) Subfamily: Sternino-Terns

105. Sandwich-tern [Sterna sandvicensis sandvicensis Latham; Sterna cantiaca Gmelin]. Summer visitor to our coasts. Local. Bird of passage.

Bird. Length 16.5 in. The Terns are sometimes called seaswallows owing to their general resemblance to the swallow tribe in appearance, allowance being made for the much larger size and the grey coloration. The present form may be distinguished from the following by its black relatively long beak with yellow tip, black legs, and the striking

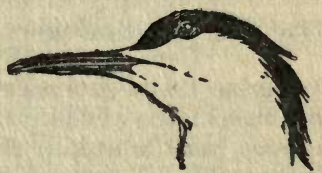

Fig. 64 . velvety black mane-shaped crest-and its habit of nesting in close packs. In flight its stouter build, longer beak and shorter tail aid recognition; also its distinctive note-a sharp Kirr-whit. Top of head and nape black. Upper-parts and wings mostly pearl-grey, but rump and tail white. Under-parts white with a not very apparent salmon-pink tinge. The young show black or dusky markings on the upper-parts.

Nest. Place: usually near the sea on sand among marram grass and the like, in shingle, also on mud-banks. The nest scrape is either unlined or more or less lined with grass and odds and ends picked up on the shore. Species breeds in colonies. 
Eggs. Usually 2. Greyish to deep buff, spotted and blotched with shades of brown and underlying ash or brown. Av. size, $2.03 \times 1.42$ in. Laying begins in the first half of May. One brood.

106. Common-tern [Sterna hirundo Linnæus; Sternc fuviatilis Naumann]. Summer visitor, and found breeding usually on the sea-coast in the British Isles.

Bird. Length $14 \frac{1}{4}$ in. See Sandwich-tern. Easily confused
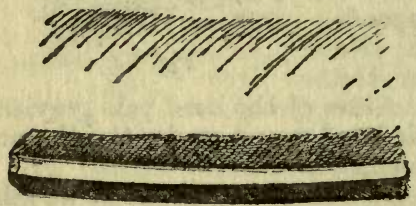

Fig. 65. Arctic-tern's primary.

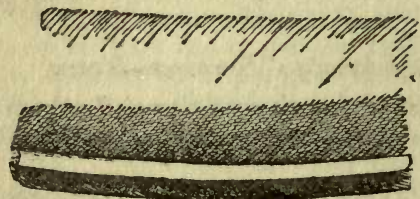

Fig. 66. Common-tern's primary. with the Arctic-tern, which it closely resembles. Both have the upper-part of the head and nape black, the rest of the plumage mostly a silvery-grey, the white rump, throat, and upper and under-tail coverts excepted; legs red. They may be distinguished most surely by the relative breadth of the dark inner band on the outer primaries and the coloration of the bill, which is blood-red to the tip in the Arctic and in the common-tern, coral red on the basal two-thirds, dusky on the third from the tip. The Arctic form has shorter legs. The rare roseate-terndiffersfrom both in having the breast rosy tinted, the beak black, the tail longer, the inner webs of the primaries all white. In autumn all three species have white on the crown and are paler on the underparts. Fledglings may be easily recognised by their buffcoloured markings.

Nest. Place: shingle bed, sand with or without vegetation, turf, bare rock, usually near the sea in the British Isles. The nest-scrape may be either unlined or lined with dry grass and other vegetable matter picked up near by, also pebbles, shells, and sometimes rabbit bones. Species breeds in colonies.

Eggs. More often 3 than 2. Dull greyish, cream or deep buff, blotched and spotted with shades of brown and ash. Rare varieties with blue and red grounds. Av. size, 1.61 $\times$ 1.19 in. Laying begins end of May to early June. One brood. 107. Arctic-tern [Sterna paradiscea Brünnich; Sterna macrura Naumann]. Summer visitor to our coasts and generally 
more northerly in its breeding range than the common-tern, but the two are found breeding together on the Farnes and elsewhere. Bird of passage.

Bird. See common-tern, No. 106.

Nest. Practically the same as the common-tern, except that the species is more definitely marine in its choice

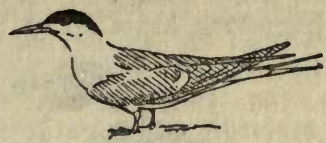

Fig. 67. of nesting site. Species breeds in colonies.

Eggs. More often 2 than 3. Like those of the commontern, but on the average the ground colour is deeper and the marking bolder. Av. size, $1.6 \times 1 \cdot 16$, therefore slightly smaller. Laying begins a few days later than in the case of the common-tern. One brood.

108. Little-tern, lesser-tern [Sterna minuta minuta Linnæus]. Summer visitor to suitable spots nearly all round our coasts.

Bird. Length $9 \frac{1}{2}$ in. While resembling the preceding species in general appearance, it may at once be recognised by its much smaller size, the white forehead, the yellow beak tipped black, and the orange-yellow legs, also by the much quicker wing-beats in flight, and the

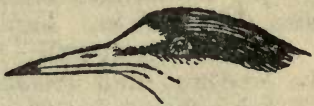

Fig. 68. sharp excited Kweeks and tiks that are its usual notes.

Nest. Place: on the beach, though abroad, like the commontern, the species nests inland on river shingle banks. The nest-scrape, found in shingle or on sand among stones, shells, \&c., is less often lined than is the case with the three preceding species. Material: usually shells or pebbles, rarely vegetable matter. Species breeds in colonies.

Eggs. 2-3. Grey to buffish or brownish, blotched and spotted with shades of brown and underlying ash-grey. Av. size, $1.25 \times .92$ in. Laying begins end May to early June. One brood.
(3) Family: Laridoe.
(b) Sub-family: Larince-Gulls

109. Blackheaded-gull [Larus ridibundus Linnæus]. Resident and common.

Bird. Length 16 in. Distinguished from the following species by its red legs and beak. Sexes much alike. In breeding dress the head is brown-not black-except for a rim of white feathers partly encircling the eye. Otherwise no marked seasonal change. Back pearl-grey. Wings the same, except the outer primaries, which have black ends and 
more or less white tips, the three outermost quills being all white except for the black ends. Rest of plumage white. Immature birds up to their second summer or later may be

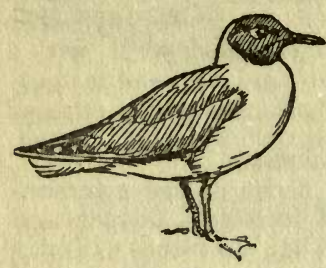

Fig. 69. distinguished by the black terminal band of the tail, and the fledglings by the buff and brown margins to the feathers.

Nest. In colonies. Place: two types (1) on the ground, on tussocks, or among water-plants in marshland, or on the edge of lakes inland or by the sea; (2) less often among marram grass on sandhills near the sea, as at Ravenglass and Walney.

Material: varies according to the locality; marram grass, roeds, \&c.

Eggs. Usually 3. Shades of buff, brown, and olive-green, spotted andblotched with blackish-brown and underlying purplegrey. Sometimes bluish and reddish types are found. Av. size, $2.2 \times 1.46$ in. Laying begins in April. One brood usual.

110. Common-gull [Larus canus canus Linnæus]. Resident in Scotland and Ireland. A winter visitor to England and Wales, except for immature birds, which may be seen in summer. Has nested on the Farnes (1910). Bird of passage.

Bird. Distinguished from the herring-gull by its distinctly smaller size-18 in. to the herring-gull's 24 -and from both this species and the smaller blackheaded-gull (16 in.) by its yellowish-green beak and legs. Sexes alike or nearly so. Back and wings pearl-grey, except the primaries, which are black or grey tipped white, except the outermost, which is tipped black. Rest of plumage white, but after the autumn moult the head and neck are streaked with ash-brown. Immature birds may always be distinguished by the black terminal rim of the tail, and by the dominant ash-brown - of the plumage, in which it differs from the immature blackhead.

$N$ est. On the vegetation-covered tops of low-lying islands and cliffs, on shores of lochs, and on hillsides. Material : grasses, heather, sea-weed, \&c. Species nests usually in colonies.

Eggs. Usually 3. Clay or stone yellow to shades of brown. Spotted, blotched and streaked with blackish-brown and underlying ash-grey. Greenish and blue varieties. Av. size, $2.3 \times 1 \cdot 6$ in. Laying begins in May.

111. Herring-gull [Larus argentatus argentatus Pontoppidan]. The most widely distributed of our breeding gulls.

Bird. Av. size, 24 in. Distinguished from the preceding species by its larger size and dull pinkish or flesh-coloured 
legs. Back pearl-grey, also the wings except for its white tips, and the black on the primaries. Rest of plumage white. Bill yellow with red at the angle. After the autumn moult the head and neck are streaked with ash-grey. The young are mottled brown ; remain immature 4-5 years, with a gradual transformation to the adult grey and white plumage.

Nest. Place : varied, usually cliff ledges, vegetation-covered tops of islands, shingle beds and moorland. Material : grass, heather, and other accessible material. Species nests usually in colonies.

Eggs. Usually 2-3. Shades of buff, olive-brown, or green, rarely whitish or blue, more or less spotted, blotched and streaked with brown and underlying purples. Av. size, $2.7 \times 1.9$ in. Laying begins April-May. One brood normally.

112. Lesser blackbacked-gull [Larus fuscus fuscus Linnæus]. Resident, found breeding mostly in W. England and Scotland.

Bird. Length 22 in. At once distinguished from the preceding, which it nearly equals in size, by the dark slate-grey on the back and wings and its yellow logs, White tips to the scapulars and wing quills, with white "mirrors" or terminal patches on the one or two outermost primaries. Rest of the plumage white, but in winter the head and neck are streaked with ash-brown, Beak yellow with red at the angle. The young are mottled brown, but, as might be expected, darker than those of the herring-gull, the back growing still darker

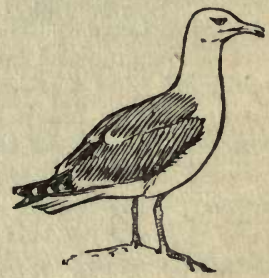

Fig. 70. as maturity approaches in the fourth or fifth year.

Nest. Place : usually on the vegetation-covered tops of islands, on moors inland, rarely cliff ledges, in which it differs from the herring-gull. Material: as herring-gull. Species nests usually in colonies.

Eggs. Usually 2-3. Like the herring-gull's, both in coloration and size. Laying begins in May. One brood usual.

113. Great blackbacked-gull [Larus marinus Linnæus]. Resident, breeding chiefly in Scotland and the west coast of Ireland.

Bird. Length $30 \mathrm{in}$. Resembles the preceding species in its black and white plumage, but is at once distinguished from it at all ages by its much larger size. It resembles the herringgull in having flesh-coloured legs.

Nest. Usually on some small islet or top of a stack. Material: as the two preceding species. Singly or small colonies. 
Eggs. Usually 2-3. Much like those of the two preceding species, but more boldly marked and larger. Av. size, $3 \times 2 \cdot 13$ in. Laying begins April-May. One brood usual.

114. Glaucous-gull [Larus glaucus Brünnich]. Winter visitor, chiefly to our north and east coasts. Occurs in summer, but not to breed.

Bird. Length 29 in., therefore about the same size as the preceding species, from which it may be distinguished in adult plumage by the entire absence of black. Mantle and wings mostly pearl-grey ; rest of plumage white. Legs pink. Beak yellow with patch of orange on the angle of the lower mandible. Size apart, No. 114 applies also to the rarer Icelandgull (22 in.), which is also a winter visitor.

The young is mottled greyish-buff, which grows paler until the plumage becomes wholly white in the fourth year, to be followed by the grey and white of the adult stage.

115. Kittiwake [Rissa tridactyla tridactyla (Linnæus)]. Resident and widely distributed. Strictly marine.

Bird. Length 16 in. Same size as the blackheaded-gull, but distinguished both from it and the common-gull by the vestigial hind-too-usually a warty excrescence with a small claw-by the black or dark grey legs, and, in flight, by the conspicuous black triangular tip to the wings; also by its note, Kitti-way-ék, which gives it its name. Mantle and wings mostly bluish-grey, rest of plumage white. Beak greenishyellow, black in the fledgling, and the inside of the mouth a gorgeous orange-red, yellow in the fledgling. Fledgling and immature birds have a more or less complete dark collar, a greyish-black band on the wings and dark rim to the tail, but resemble the adults in the general white-grey of the plumage, thus differing conspicuously from other young gulls.

Nest. Place: on ledges of cliff faces or walls of sea-caves. Material: sea-weed, grass, moss, earth. Usually a solid structure. Species nests in colonies, often with razorbills, guillemots, puffins, and gannets.

Eggs. 2-3. Greyish-white to olive-buff, spotted and blotched with dark brown and ash-grey. Av. size, $2 \cdot 21 \times 1 \cdot 6$ in. Laying begins end May to early June. One brood.

(3) Family: Laridoe. (c) Subfamily: Stercorariino-Skuas

116. Great-skua, bonxie, skooi [Megalestris skua (Brünnich); Megalestris catarrhactes (Linnæus)]. Breeds in Shetland. Elsewhere winter visitor to our coasts.

Bird. Length 21 in. Recognised by the hooked upper mandible and bluish cere, the general umber-brown of the plumage, and the large white patch across the dark brown 
primaries. Beak and legs black. The brown of the upper parts streaked chiefly buff or rufous. Under-parts rufous with paler streaks, noticeable on the flanks.

Nest. On open vegetation-covered slopes near the sea. A depression lined more or less with dry grass, heather, feathers, \&c. Species breeds in colonies.

Eggs. Usually 2. Shades of olive-brown or green, spotted and blotched with brown and ash-brown. Av. size, $2.73 \times 1.93$ in. Laying begins in mid-May. One brood.

117. Arctic-skua, Richardson's skua, shooi [Stercorarius parasiticus (Linnæus); Stercorarius crepidatus (Gmelin)]. Breeds in N. and W. Scotland. Elsewhere a winter visitor. Rare on south coast.

Bird. Length $20 \mathrm{in.}$ Distinguished from the preceding by its smaller body, shorter wings (13 as against $16 \mathrm{in.}$ ), and long pointed central tail-feathers ( $7-8$ in. long). It may be distinguished from the rarer long-tailed or Buffon's skua by having all the shafts of the primaries white, instead of only the two outer on each side. Coloration of plumage varies greatly, but there are

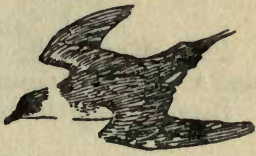

Fig. 71. two marked types, a light and a dark with intermediate varieties. The dark has the plumage mostly sooty-brown. The light type has the under-parts and sides of the neck whitish or creamy-white, with upper-parts brown. A conspicuous yellowish tinge is in nearly all cases present on the sides of the neck and head. Legs black.

Nest. Vegetation-covered slopes, or moorland, usually near the sea. A depression, with scanty lining of rough grass, heather, \&c. Species breeds in colonies.

Eggs. Usually 2. Much like those of the great-skua, but smaller. Av. size, $2.18 \times 1.61$ in. Laying begins end May to early June. One brood.

\section{(4) Family: Edicnemido-Stone- curlews}

118. Stone-curlew, Thick-knee, Norfolk-plover, great-plover. [EEdicnemus cedicnemus (Linnæus); EEdicnemus scolopax (S. G. Gmelin)]. Local

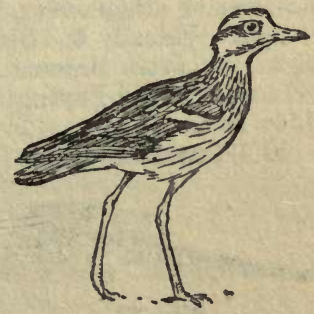

Fig. 72. summer visitor to south and east England. Casual visitor to other parts. A few winter in S.W. England.

Bird. Length 16 in. Distinguished by the large yellow 
eye and the long yellow legs. Upper-parts mostly buff streaked with dark brown. Two white bars on the wing. Wing quills dusky with white patches near the tips of the outermost. Under-parts white or whitish, except the forebreast and flanks, which are tinged pale brown streaked dark brown. Irregular white patch on the side of the head. Beak yellow with black tips.

Nest. On the ground, on open commons, and wasteland. The nest-scrape is scantily lined with bents, pebbles or rabbit droppings.

Eggs. Normally 2. Generally of a shade of buff, blotched, streaked and spotted with browns and underlying ash-grey. Av. size, $2.1 \times 1.52$ in. Laying begins April-May. One brood.

(5) Family: Charadriidoe. (a) Subfamily: ScolopacinceWoodeock and Snipes

119. Woodcock [Scolopax rusticola Linnæus]. Resident and widely distributed in our woodlands.

Bird. Length $14 \frac{1}{4}$ in. Distinguished from the following

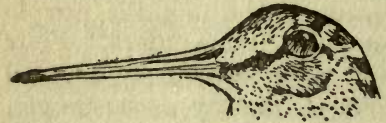

Fig. 73. species by its larger size, the broad dark bands which cross the nape and the hinder half of the head and from side to side, and by the much narrower and more defined dusky bars across the pale buff or whitish breast. On the back and wings is an intricate pattern of chestnuts and blacks, varied with silver-grey. Primaries dark grey with patches of chestnut and white tips.

Nest. A depression on the ground, usually in a wood among bracken or other cover, lined with a few leaves or moss.

Eggs. Usually 4. Shades of yellow and brown spotted and blotched with browns and underlying ash-grey. Av. size, $1.74 \times 1.33$ in. Laying begins March-April. One brood, possibly two.

120. Common-snipe [Gallinago gallinago gallinago(Linnæus);

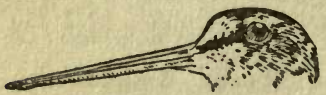

Fig. 74. Gallinago coelestis (Frenzel)]. Resident, prefers marshy areas.

Bird. Length 10 in., therefore distinctly smaller than the woodcock, from which it may also be distinguished by the arrangement of the lines on the crown, which pass from front to back. The lines are three in number, and buff on a dusky brown ground. The pattern of the upper-parts is chiefly of black and shades of buff with grey added on the wings. Along the back run 
four parallel stripes or bands of buff. The black tail is banded with tawny yellow and has a white terminal rim. Under-parts mainly white or whitish, more or less vaguely barred with dusky grey.

Nest. A depression in the ground in a marshy place, sometimes among heather. Lined with dead grasses.

Eggs. Normally 4. Pear-shaped with ground-colour varying from greenish or yellowish-green to olive-brown, more or less heavily spotted or blotched with shades of brown and underlying ash-grey. Av. size, $1.56 \times 1.12$ in. Laying begins March-April, and later in the north. One brood, sometimes two.

121. Jack-snipe [Gallinago gallinula (Linnæus)]. Generally distributed winter visitor. Also bird of passage (E. Clarke). Marshes and coast.

Bird. Length $7 \frac{1}{2}$ in., therefore distinctly smaller than the preceding, from which it may be further distinguished by having twelve instead of fourteen tailfeathers, by the absence of a marked

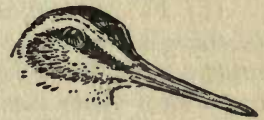

Fig. 75. central buff stripe on the crown, and by the metallic purple of the rump and the metallic greens on the scapulars. Four buff stripes along the back. Under-parts mostly dull white more or less streaked with dark brown.

(5) Family: Charadriidoe. (b) Subfamily: Charadriinoe-Plovers

122. Dotterel [Eudromius morinellus Linnæus]. Summer visitor, chiefly to Scottish hills. Bird of passage.

Bird. Length 9 in. At once distinguished from the other British plovers by the white band across the upper breast and the large conspicuous patch of chestnut below it. Upper-parts mostly ash-brown with paler edges. A marked white stripe passing over the eye backward. A brownish-black patch on the lower breast. Belly and tail-coverts white. After the autumn moult the black and chestnut of the under-parts give way to white. Fledglings differ greatly, sufficient for recognition being the buff eye-stripe, breast and flanks, and the absence of the white breast band.

Nest. High up on barren mountain slopes. A depression scantily lined with bents or other material.

Eggs. Usually 3. Yellowish or olive boldly blotched with deep black-brown and occasionally with underlying ash-grey. Av. size, $1.62 \times 1 \cdot 14$ in. Laying begins in June. One brood.

123. Ringed-plover ringed-dotterel [Agialitis hiaticula hiaticula (Linnæus)]. Resident, chiefly on our coasts. 
Bird. Length nearly 8 in. Recognised by the uniform greyish-brown crown, back and wing-coverts, the white underparts broken by a broad black band passing across the upper breast and upwards round the neck, the

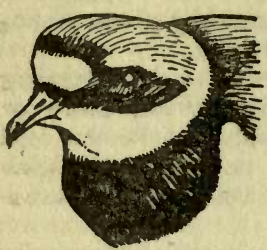

Fig. 76. orange legs and the curious black and white markings of the head and neck shown in the figure. Beak orange with black tip. The fledgling lacks the black band across the forehead, and has a dusky beak. The rare Kentish-plover has black beak and legs, and the black breast band is reduced to two patches on either side of the neck. It breeds coast of Kent and Sussex.

Nest. On the ground, usually on sand or shingle beds near the sea, occasionally inland. The nestscrape may be unlined, or lined with broken shells, pebbles, bents and other accessible material.

Eggs. Normally 4. Pear-shaped, yellowish spotted brownishblack. Av. size, $1.34 \times 95$ in. Laying begins April-May. One, possibly two broods.

124. Golden-plover [Charadrius apricarius Linnæus ; Charadrius pluvialis Linnæus]. Resident and generally distributed. Breeds on hilly districts of Scotland, Ireland, Wales, and W. England.

Bird. Length 11 in. Recognised by the black or dusky upper-parts richly spotted with yellow, and by

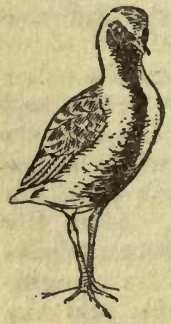

Fig. 77. the black face and under-parts, this black area being broadly margined with an irregular band of white that crosses the forehead, and passes behind the eyes down each side of the neck and breast to the white under tail-coverts. Under surface of the wing white including the axillaries. No hind toe. Black beak and legs. After the autumn moult the under-parts are white, tinged on the fore-neck with yellow mottled dusky. The fledglings have the under-parts white with dusky brown bars on the flanks.

Nest. On moorland or rough pasture. A scrape in the ground, usually among heather or tufts of coarse herbage. Unlined or scantily lined with bits of heather, dry grass and other material.

Eggs. Usually 4. Pear-shaped. Shades of yellow spotted and blotched brown-black. Rarely greenish-white ground. Av. size, $2.02 \times 1.35$ in. Laying begins April. One brood, possibly more.

125. Grey-plover [Squatarola squatarola (Linnæeus); Squatarola 
helvetica (Linnæus)]. Winter visitor to our coasts. Bird of passage. Occasional non-breeding birds in summer.

Bird. Length $11 \frac{1}{2}$ in. Not unlike the golden-plover in the general pattern of its plumage, but easily distinguished from it, in summer, by the black and white barred upper-parts, and at all seasons and ages by the black axillaries, conspicuous against the light under-surface of the wing, and by the white upper tail-coverts. In summer the under-parts and face are black banded marginally with white as in the case of the golden-plover. Short hind toe. Legs and beak black. After the autumn moult the under-parts are mostly white. Forebreast ash-brown with dusky mottlings. The upper-parts are mostly ash-brown more or less marked with whitish and dusky. The young resembles somewhat that of the goldenplover, with the marked difference above noted.

126. Lapwing, green-plover, peewit [Vanellus vanellus (Linnæus); Vanellus vulgaris Bechstein]. Resident and generally distributed.

Bird. Length $12 \frac{1}{2}$ in. Recognised by the glossy greenblack crest and crown, the coppery-green mantle glossed purple, the tail white on the basal part and sides, rest black; the white under-parts with metallic-hued black on the throat and upper breast, and the conspicuous chestnut colour of the upper and under tail-coverts. In flight recognition is aided by the broad rounded wings, and by the under-surface of the same, which is black with white axillaries. After the autumn moult the throat is white. The male has the larger crest.

Nest. On pasture, marsh, or moor. A scrape in the ground, lined with bents or other material.

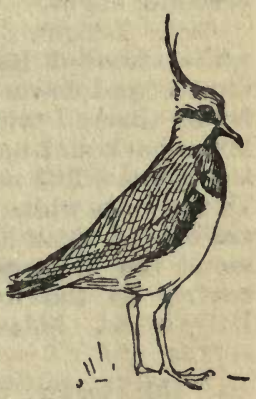

Fig. 78.

Eggs. Usually 4. Pear-shaped. Yellowish, or olive-brown to olive-green thickly spotted and blotched with black-brown. Greenish-blue varieties. Av. size, $1.83 \times 1.31$ in. Laying begins end of March to early April. One brood.
(5) Family: Charadriidoe.
(c) Subfamily: Hoematopodince.

127. Oyster-catcher, sea-pie [Homatopus ostralegus ostralegus Linnæus]. Winters on all our coasts. Breeds on coast and inland, but scarce in S. and E. England.

Bird. Tuength $16 \frac{1}{2}$ in. Easily distinguished by the long 
bright orange-red beak and black and white plumage. See the figure. The lower back, rump, and basal half of tail white. Legs flesh-colour. After the

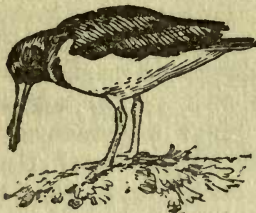

Fig. 79. autumn moult the black of the neck is broken by an irregular band of white. The fledgling has pale buff margins on the wings and tail-coverts.

Nest. On rough ground, rocks, or sand ; usually near the sea. A scrape lined with pebbles, shells, bits of grass, and other material.

Eggs. Usually 3. Yellowish or rufousyellow spotted, blotched, and scrawled with black-brown and underlying ash. Greenish-blue ground rare. Av. size, 2:22 $\times 1.54$ in. Laying begins usually in early May. One brood.

128. Turnstone [A renaria interpres (Linnæus); Strepsilas interpres (Linnæus)]. Name due to habit of turning over stones in search of food. Winter visitor to our shores and bird of passage. Seen also in summer, but evidence of breeding slight.

Bird. Length 8 in. In summer the crown and nape are white streaked black, the white of the nape extending to form a band down each side of the neck. The mantle mostly boldly marked with black and chestnut. The white of the lower back and upper tail-coverts is divided by the black of the rump. Tail mostly dark grey with white bases and tips. Under-parts white, except the forebreast and neck-band, which are black. Beak black. Legs orange-red. After the autumn moult the upper-parts are mostly brown, with dusky brown centres to the feathers. Throat white. Breast as back. Belly white. Sides of the head ash-brown mixed with white.

(5) Family: Charadriidce. (d) Subfamily: Tringince.

129. Dunlin [Erolia alpina alpina (Linnæus); Tringa alpina Linnæus]. Very common

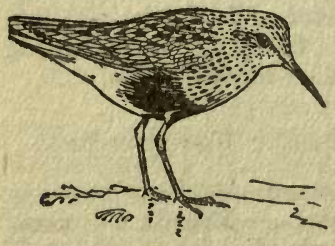

Fig. 80. winter visitor on our coasts, where non-breeding birds can also be seen in summer. Breeds in Scotland, and very sparingly elsewhere.

Bird. Length $7 \frac{1}{2}$ in. Sexes alike, but female larger. The accompanying figure of the dunlin may be taken as generally typical of the Family, its members having long legs enabling them to wade in shallow 
water, and comparatively long beaks. In breeding plumage the crown and nape are streaked black on pale chestnut, and the mantle black with pale chestnut margins. Upper tailcoverts dark brown, rump ash-brown. Tail ash-grey with central feathers dark brown. Wing-coverts mostly ash-grey, and the quills brownish-black with a white bar on the secondaries. Under-parts white, except for the black streaks on the forebreast, and the broad black of the lower breast. Legs black. After the autumn moult the upper-parts mostly ash-brown, more or less ștreaked with dark grey, and the underparts white.

Nest. High-lying marshes or moorland, or low-lying rough pasture or marsh by the sea. A scrape in the ground, among coarse grass, heather, or other herbage, lined with grasses.

Eggs. Usually 4. Pear-shaped. From greenish to yellowish or yellow-brown blotched, spotted, and streaked with dark brown, and underlying ash. Av. size, 1.34 $\times .95$ in. Laying begins in May. Probably one brood only.

130. Purple-sandpiper [Erolia maritima maritima (Brünnich); Tringa maritima Gmelin]. A winter visitor and bird of passage to our coasts.

Bird. Length $8 \frac{1}{2}$ in. See No. 129. Distinguished from the preceding species by the short yellow legs and darker plumage. In the breeding plumage the upper-parts are mostly black glossed purple, with pale rufous or buff margins on the mantle. Secondaries show much white. Central tail-feathers black glossed purple, the rest grey with narrow white margins on the outermost. Under-parts whitish obscured by dark brown streaks on the neck, breast, flanks, and under tailcoverts. After the autumn moult the feathers of the upperparts are margined with dark grey.

131. Knot [Erolia canutus (Linnæus); Tringa canutus (Linnæus)]. Named after its hoarse grunting note: Knot or Knut. Winter visitor to our coasts and bird of passage. Some non-breeding birds remain through summer.

Bird. Length 10 in. See No. 129. A marked difference between the breeding and winter plumage. Easily distinguished in breeding dress from the two preceding species by the rich bay or reddish-brown of the under-parts, head, and neck; the crown and hind-neck being, however, heavily streaked with black. Back black with bay margins. Wingcoverts mostly ash-brown margined chiefly with white. After the autumn moult the under-parts lose the bay and become white with greyish streaks. The upper-parts ash-grey with darker streaks. Upper tail-coverts, which in summer show more or less bay with white and some black, are now white 
barred black. Young birds resemble the adults in winter plumage, but have a buff tinge. The rarer and smaller curlew-sandpiper (8 in.), which has also bay on the head and under-parts in summer, may always be distinguished by the slightly down-curved beak. See also godwit (No. 136).

132. Sanderling [Caledris leucophœa (Pallas); Calidris arenaria (Linnæus)]. Plentiful on our shores in the autumn, but most pass south to winter.

Bird. Length 8 in. See No. 129. Distinguished by the absence of the hind toe. In spring or breeding plumage it has the upper-parts with the head, neck, and forebreast mostly rufous streaked black. Lower breast and belly white. After the autumn moult the upper-parts are mostly ash-grey with darker striations, the neck and under-parts white. Some individuals seem almost wholly white. The immature birds, which are very numerous, may be distinguished by the much darker upper-parts, the mantle being chiefly mottled black and white, with some buff on the wing-coverts and neck.

133. Common-sandpiper [Tringa hypoleuca Linnæus; Totanus hypoleucus (Linnæus)]. Summer visitor to inland lakes and rivers, chiefly in hilly districts. Rare in the S.E. counties. Bird of passage.

Bird. Length 8 in. Recognised in breeding plumage by

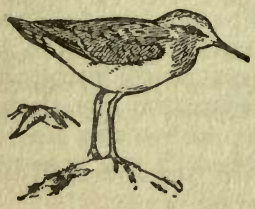

Fig. 81. the bronze-brown upper-parts, minutely flecked, barred, and striated with umberbrown, and the white under-parts with dusky streaks on the neck and forebreast. A white bar on the extended wing. Tail white at end and sides. Legs yellowish. After the autumn moult the umberbrown markings almost disappear, leaving the upper-parts a more uniform colour.

Nest. Usually on the ground among shingle or herbage near a stream or lake-side. Lined with dry grasses or other material.

Eggs. Usually 4. Pear-shaped. Buff spotted with brown, and underlying ash-grey. Av. size, $1.4 \times 1.01$ in. Laying begins in May. One brood.

134. Green-sandpiper [Tringa ocrophus Linnæus; Totanus ocrophus (Linnæus)]. Winter visitor and bird of passage. Scarce on W. and N. coasts of Scotland, and in Ireland. Not proved to breed in British Isles.

Bird. Length $9 \frac{1}{2}$ in. Distinguished from the preceding by the greenish upper-parts, mostly marked with small whitish spots (buff in the young), by the white upper tail-coverts, and the dusky under-surface of the wing. Under-parts white with 
olive-green markings on sides of the breast. Tail barred dark green. The much rarer wood-sandpiper ( $8 \frac{1}{2}$ in.) resembles this species, but is recognised by the white under-surface of the wings. It is a bird of passage, chiefly on the S. and E. of England.

135. Redshank [Tringa totanus (Linnæus); Totanus calidris (Linnæus)]. Resident and widely distributed, but local as a breeding species.

Bird. Length 11 in. In shape not unlike No. 133. Recognised by the brilliant red legs, and the white on the wing (inner primaries and secondaries) and on the rump. Upper-parts mostly greyish-brown heavily marked with dusky brown, grey, and black. Tail barred black. Under-parts white streaked on its upper area and more or less barred on the lower area with dusky grey. Beak red, dusky on the end half. After the autumn moult the upper-parts are greyer, and the under-parts more faintly marked. The rarer greenshank (summer visitor to N. Scotland, mostly bird of passage elsewhere) is distinguished from the redshank by its larger size (14 in.), the olive-green legs, slightly up-curved beak, and the general dark greyish hue of the upper-parts.

Nest. Nests usually not far apart on the upper beach, rough pastures, or moorland. Well concealed in rough herbage, also more or less exposed. More or less lined with dry grass. Gregarious breeding species.

Eggs. Usually 4. Pale to deep yellowish spotted and blotched with browns and underlying ash-purple. Greenish ground rare. Av. size, $1.75 \times 1.21$ in. Laying begins end March to mid April or later. One brood.

136. Bartailed-godwit [Limosa lapponica lapponica (Linnæus)]. Winter visitor and bird of passage on our coasts.

Bird. Length $15 \frac{1}{2}$ in. See No. 129. In breeding dress may be recognised by its relatively large size, the bright bay on the head, neck, and under-parts, the brownish-black and bay pattern of upper-parts, the long slightly up-curved beak. Under wing surface mostly white. Tail-coverts and rump white, more or less barred and streaked black. Tail mostly white barred with black. After the autumn moult the bay colour is lost. Pattern of the upper-parts ash-grey and white with darker streaks. Under-parts white, except the upper breast and flanks, which are grey with darker streaks. Tail ash-grey with bars absent, or almost so. Female paler. Fledgling like adult in winter, but tail barred and a buff tinge on neck, breast, and flanks. The rarer blacktailed godwit (16 in.) resembles the bartailed, but may be distinguished at all seasons by the broad black end to the tail, whence its name. 
137. Curlew [Numenius arquata arquata (Linnæus)]. Common on our own coasts in winter, rarer summer. Home birds breed inland, but scarce on E. side of England. Local.

Bird. Length 21-26 in. Female larger. Recognised by its

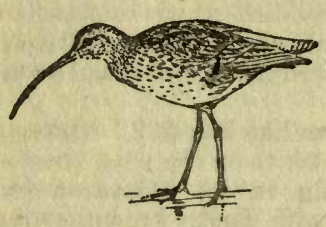

Fig. 82. large size, the long down-curved beak (5-6 in.), the light and dark brown pattern of the upper-parts and tail, the white rump excepted, and the mostly whitish under-parts streaked brown.

Nest. On moorland, rough pastures, and marshy ground. A scrape in the ground, lined usually with dry grasses. Eggs. Usually 4. Pear-shaped. Greenish or olive-brown spotted and blotched with brown, and underlying ash-grey. Rarely bluegreen unmarked. Av. size, $2.65 \times 1.86$ in. Laying begins April-May. One brood.

138. Whimbrel [Numenius phceopus phoopus (Linnæus)]. Chiefly bird of passage. A few breed in Orkneys and Shetlands, and possibly some of the Western Isles.

Bird. Length 16-18 in., therefore much smaller than the curlew, which it resembles in coloration and in the long downcurved beak ( $3 \frac{1}{2}$ in.). It differs in having a broad pale band down the middle of the dark brown crown.

Nest. On moor or marsh. Scrape, lined with moss, lichen, and other material.

Eggs. Usually 4. Broad pear-shaped. Greenish to pale or deeper brownish boldly blotched with darker brown, and underlying ash-grey. Av. size, $2 \cdot 30 \times 1 \cdot 61$ in. Laying begins May-June. One brood.

\section{ORDER: GRUIFORMES \\ Family: Rallidoe-Rails}

139. Corncrake, landrail [Crex crex (Linnæus); Crex pratensis

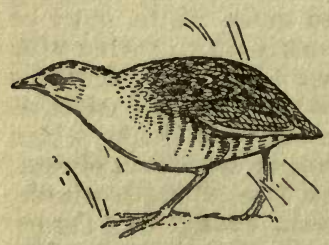

Fig. 83. Bechstein]. Summer visitor to our grass-lands, but local. Occasionally remains through winter.

Bird. Length $10 \frac{1}{2}$ in. Recognised by its rasping crake, its wedgeshaped body, the yellowish-brown upper-parts with broad dark streaks ; the paler under-parts barred, not streaked, on the flanks with brown, and the chestnut wings. Greyish above the eye, on the cheek, throat, and breast. This grey, 
which is paler in the female, gives place to yellowish after the autumn moult.

Nest. Usually in high grass. A scrape in the ground, lined with grasses and other material.

Eggs. Usually 8-11. Buffish or reddish-white spotted or blotched with reddish-brown, and underlying ash-grey. Av. size, $1.42 \times 1.02$ in. Laying begins in May. One brood, possibly two.

140. Water-rail [Rallus aquaticus aquaticus Linnæus]. Resident. Frequents marshy areas.

Bird. Length $11 \frac{1}{2}$ in. As skulking in its habits as the land-rail. Distinguished from it and the two following species by the relatively long, wholly red beak, the conspicuously white and black vertically barred flanks, and in summer by the uniform lead-grey of the neck and breast. The upper-parts are brown with broad black streaks. After the autumn moult the grey is mixed with brown. The fledgling has white bars on the wing-coverts.

Nest. In osier beds, among reeds and other aquatic plants. A fairly large structure of sedges, reeds, and the like.

Eggs. Usually 7-12. Creamy-white generally sparingly spotted with red-brown, and underlying ash-grey. Bold blotches rare. Av. size, 1.37 $\times 1.02$ in. Laying begins in April. Broods 1-2.

141. Waterhen, inappropriately called moorhen [Gallinula chloropus chloropus (Linnæus)]. Resident and widely distributed.

Bird. Length 13 in. Recognised by the conspicuous under tail-coverts (frequently jerked up) which are white with median stripe of black, and by the white broken line along the upper feathers of the flanks, these white parts being in strong contrast with the dusky hue of the rest of the plumage. Head, neck, and under-parts slate-black. Upper-parts olive-brown glossed green. The forehead shield and beak bright red, except the tip

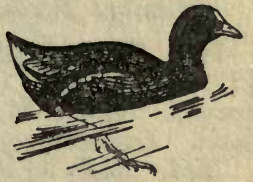

Fig. 84 . of the latter, which is lemon-yellow. Legs green with a "garter" of red and yellow at the top. Young birds may be recognised by the dull grey or white on the under-parts and the greenish bill and shield.

Nest. Usually among rushes or other aquatic plants, or by ponds and lake or river margins; also on the ground away from water, or in hedges, bushes, trees. Strongly built, usually of various water-plants, lined with finer material, grasses, \&c. ; also dry leaves. Extra nests are built, apparently for roosting and resting. 
Eggs. Usually 6-10. Light buff to clay-yellow more or less spotted or blotched with brownish or purplish-red, and underlying ash-grey. Av. size, $1.76 \times 1.25$ in. Laying begins in April, sometimes earlier. $2-3$ broods.

142. Coot [Fulica atra atra (Linnæus)]. Resident. Found

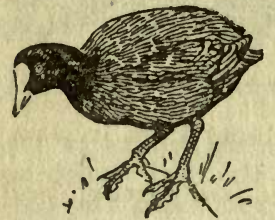

Fig. 85 . chiefly on the larger sheets of water; also on coast in hard weather.

Bird. Length 15 in. Sexes nearly alike. Recognised by the curious lobed toes (Fig. 86), the white beak and forehead shield, and the slate-grey plumage relieved only by the white tips to the secondaries. Head and neck nearly black. Legs green. Young birds may be recognised by the white on the under-parts.

Nest. Usually on lake margins in shallow water among reeds and other aquatic plants. A bulky structure of aquatic plants.

Eggs. Usually 7-9. Greyish to clay-yellow speckled all over with small purplish-brown or brownblack spots. Av. size, $2 \cdot 1 \times 1.41 \mathrm{in}$. Laying begins March-April or later. One, possibly two broods.

\section{ORDER : GATIIFORMES}

Family: Phasianidae. (a) Subfamily: Tetraonina-Grouse

143. Capercaillie, capercailzio [Tetrao urogallus urogallus Linnæus]. Resident. Breeds in Scotland. Local movements.

Bird. Male 35 in., female 25 in.,

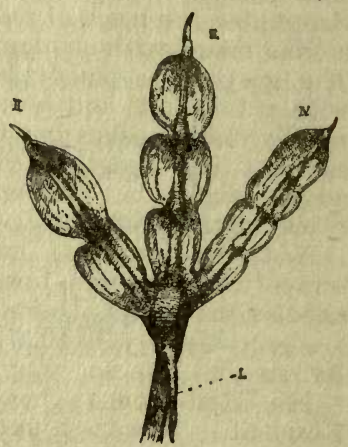

Fig. 86. Coot's toes. therefore larger than the other grouse (Nos. 144-146). Like them it has the wings short and rounded. The male has the upper-parts freckled grey, except the wing-coverts and scapulars, which are reddish-brown freckled black. Throat feathers long and black. Under-parts blackish with glossy dark green on the breast and white tips to the belly feathers. The much smaller female differs markedly in coloration, which is buff, and mostly rufous-buff on the upper-parts, barred and spotted with black, brown, and white. Conspicuous orangebuff on the throat and breast. The feathers on the lower breast and belly have conspicuous black and white tips. Both sexes have the legs feathered, and a bare red patch or wattle 
about the eye, larger in the male. The fledgling is not unlike the female, but shows more buff.

Nest. Usually in a pine-forest, at the foot of a tree; also under a bush, in heather, or other cover. The nest-scrape is lined with pine-needles, moss, feathers.

Eggs. Usually 6-8. Yellowish to reddish-yellow speckled, spotted, and finely blotched with browns. Av. size, $2 \cdot 27 \times$ 1.62 in. Laying begins end April. One brood.

144. Black-grouse, blackgame; blackcock (male), greyhen (female) [Tetrao tetrix (Linnæus)]. Resident. Breeds chiefly in the northern counties and Scotland. Absent from Ireland. Local movements.

Bird. Length 23 in. The blackcock is easily recognised by the lyre-shaped tail, the conspicuous white under tail-coverts and less marked white bar on the wing, both contrasting with the general blue-glossed black of the plumage. In JulySeptember the black of the upper-parts is for a time mixed with chestnut or brownish-buff. The greyhen is chiefly barred and freckled with rufous-buff and black. The forked-tail readily distinguishes her from the hen capercaillie. The fledglings are much like the adult female, but young cocks soon show black in the plumage.

Nest. In woodland or open ground. A scrape in the ground, lined with leaves, pine-

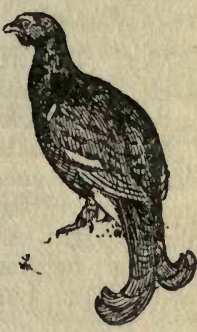

Fig. 87. needles, moss, and other material.

Eggs. Usually 6-10. Like the capercaillie's, but smaller. Av. size, $2 \times 1 \cdot 45$ in. Laying begins April-May. One brood. 145. Redi-grouse [Lagopus lagopus scoticus (Latham)]. Resident. Breeds in moorland districts of Scotland, Ireland, and parts of Wales, W. and N. England; exceptionally elsewhere. Local movements in winter from the high moors to the lowland.

Bird. Length $15 \frac{1}{2}$ in. The male, in breeding dress, is chestnut-red finely barred with black, the breast being darker. Legs and toes feathered white. Wing and tail quills brownish. The coloration varies much. Some individuals have the under-parts, and sometimes the upper-parts, spotted white; others are dark, occasionally almost black. From June to October the males generally

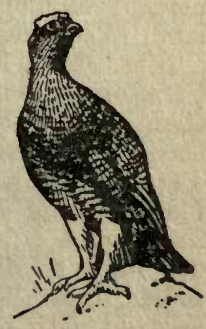

Fig. 88. become blackish on the upper-parts, with numerous irregular 
buff bars, after which they again assume the breeding plumage (November-June). The female is smaller. In breeding plumage (April-July) she resembles the male in his autumn dress, and may further be distinguished by having merely a bare red patch over the eye instead of the red crest-like erections of the male. From August to March she wears the breeding costume of the male. Like the male, the females vary in coloration, some being redder, others blacker, and others white-spotted, or, more usually, buff-spotted. An Irish variety has the upper-parts barred buff and black. The fledglings are not unlike the female in her breeding dress.

Nest. On moorland. A scrape among heather or coarse herbage, lined with grasses, moss, feathers, \&c.

Eggs. Usually 7-12. Whitish to creamy, sometimes with a reddish tinge, more or less heavily and closely blotched and spotted with reddish or blackish-brown. Av. size, 1.79 ×1.25 in. Laying begins in April, sometimes earlier. One brood.

146. Ptarmigan [Lagopus mutus mutus (Montin)]. Resident. Breeds on the mountains of Scotland. More or less stationary.

Bird. Length $14 \frac{1}{2}$ in. Distinguished at all seasons from the preceding by the large but varying amount of white on the wings. Three seasonal changes of plumage. The male (1) from April to July has the upper-parts blackish with a barred and mottled pattern of rusty grey, and the under-parts white, except the forebreast, which is brown more or less mottled rufous; (2) from August to October the upper-parts grey with black-and-white pattern, under-parts nearly all white ; (3) from November to March all white except the black on the tailfeathers, lores, and eye-stripe. Birds living at the highest altitudes appear to retain the white longer than birds lower down. The female in period (1), April-July, has the pattern of the upper-parts mostly buff, rufous-buff, grey, or white on brown; in period (2), August-October, she is darker than the male; and in period (3), November-March, differs in having no black on the head. The fledgling is mostly blackish with rufous-buff markings, and brownish-black and buff primaries.

Nest. Usually above 2000 feet on mountain-sides. A scrape on the ground, unlined, or more or less scantily lined with moss, ling, and feathers.

Eggs. Usually 8-9. Like these of the red-grouse, "but, as a rule, the ground-colour is whiter, the markings more sparingly distributed and blacker, with less of the rich deep red-brown" (Jourdain). They are slightly smaller. Av. size, 1.70 $\times 1 \cdot 20$. Laying begins about the third or fourth week in May. One brood. 
Family: Phasianida. (b) Subfamily: Phasianinoe-Pheasants.

147. Pheasant [Phasianus colchicus Linnæus]. Semidomesticated and stationary. Local in Scotland.

Bird. Length 35 in., the female with a much shorter tail. No seasonal change. The female is easily distinguished from the male by her general sandy-brown coloration, marked black, with a reddish-brown or chestnut tinge on the mantle, flanks, and tail-feathers. The most conspicuous features of the male are the dark green-purple glossed head and neck, the long reddish-buff tail barred black, the bare red cheeks, and the general tawny-reddish hue of the plumage. The fledglings are not unlike the female, but duller.

Nest. Usually on the ground, in rough tangle, or under bushes ; in a hedge, wood, or ditch-side. Occasionally in trees. The scrape is scantily lined with leaves, grass, \&c.

Eggs. Usually 8-14. Olive-brown. Rarely pale blue. Av. size, $1.81 \times 1.41$ in. Laying begins April-May. One brood.

148. Partridge, grey-partridge [Perdix perdix perdix (Linnæus); Perdix cinerea Latham]. Resident and stationary except for irregular local movements. Local in Scotland.

Bird. Length $12 \frac{1}{2}$ in. The male in breeding plumage (Sept.-June) is mostly tawny-chestnut on the head and throat, a brownish-buff on the upper-parts, with close wavy cross-lines of black. The breast and flanks are grey, finely marked with black. On the flanks broad chestnut bars. A large horse-shoe shaped chestnut patch on the lower breast. From June-Sept. the male has the neck brown, with buff and black streaks, and the throat paler. In this plumage it may be distinguished from young birds by the rounded tip of the outermost primary. The female may always be distinguished by the black wingcoverts, with wavy buff cross-bars, which she has in addition to the buff shaft streaks of the male. Horse-shoe smaller or wanting. Till May she has the head and neck brown, streaked buff; from May-Sept. the neck becomes darker. The fledgling has buff cross-bars on the wing-coverts, like the female.

Nest. Usually on the ground, in a hedge-row, in mixed tangle, under a bush, in bracken, and similar places. The scrape is lined with dead leaves and grass, which may be placed over the eggs, when left.

Eggs. Usually 10-20. Olive-brown to greyish-olive. Rarely blue. Av. size, $1.38 \times 1.05$ in. Laying begins in April-May. One brood.

149. Redlegged-partridge, French-partridge [Caccabis rufa rufa (Linnæus)]. Introduced species, resident in England and Wales. 
Bird. Length $13 \frac{1}{2}$ in., therefore somewhat larger than the grey-partridge, from which it may at once be distinguished in adult plumage by the conspicuous black, white, and chestnut barrings on the lavender-grey flanks. Female somewhat duller. No seasonal change. Upper-parts brown, except the crown, which is grey. Throat white, this white area being edged with a black band, below which again is a broader band of tawny-rufous with black tips. Breast lavender-grey. Belly buff. Legs red. The fledgling has the head and neck dull buff. Upper-parts mostly greyish-brown with black and pale buff or whitish markings. Under-parts mostly a dull greyish tawny-rufous tint with paler tips to the feathers. Flanks unmarked.

Nest. Place : as grey-partridge. Slightly lined with grass and leaves.

Eggs. Usually 10-18. Buff to rufous, finely speckled with red-brown, and more sparingly blotched with the same or purplish. Av. size, 1.59 $\times 1.21$ in. Laying begins April-May. One brood.

150. Quail [Coturnix coturnix coturnix (Linnæus); Coturnix communis Bonnaterre]. Chiefly a summer visitor in fluctuating and apparently diminishing numbers to the southern parts of England and E. Ireland. Scarce elsewhere. Some stay through winter.

Brrd. Length 7 in, therefore much smaller than the partridge. General coloration is pale brown or dusky above with pale buff or whitish stripes, and chestnut and pale buff beneath. The male has the crown and nape black, tipped brown, with a central longitudinal buff stripe, and a similar stripe passing backwards over each eye, bounded by a dusky stripe below. Back dusky or black, barred pale brown, streaked whitish. Scapulars and wing-coverts pale brown with whitish or buff shaft streaks, and barred or spotted buff and dusky. Wing quills brownish-grey barred buff. A black inverted "anchor" on the throat. Forebreast pale chestnut striated with buff. Flanks marked with black and buff. Rest of under-parts pale buff. Female lacks the "anchor," and the black on the upper-parts duller.

Nest. A scrape among crops or among grass in rough pasture, lined with grass, stems, leaves, \&c.

Eggs. Usually 7-12. Generally a yellowish ground-colour with dark brown markings varying from a few heavy blotches to innumerable spots. Av. size, $1 \cdot 14 \times \cdot 88$ in. Laying begins May-June. Broods 1-2. 


\section{ORDER : ACCIPITRES. SUBORDER : FALCONES}
(1) Family: Buteonidoe.
(a) Subfamily: Aquilince-Eagles

151. Golden-eagle [Aquila chrysaëtus chrysaëtus (Linnæus)]. Stationary in N. Scotland and in one or two places in Treland. Occasional wanderer elsewhere.

Bird. Length 32-36 in. Female the larger. Recognised by its large size and general dark brown coloration. The head and nape shade from brown to tawny, the rest of the upperparts are glossed more or less purple. A greyish band across the tail. Beak hooked. Legs feathered. Toes yellow. Young birds have the tail whitish with broad terminal band of dark brown. The rarer and slightly larger whitetailed-eagle is distinguished at all ages by the fact that its leg is not feathered. Only the adult has the tail white.

Nest. Usually on trees or ledges of crags. A mass of sticks lined with softer material such as grass, heather, moss.

Eggs. Usually 2. Whitish, variously blotched, spotted, and marbled with shades of reddish-brown, and underlying pale violet; also unmarked white. Varieties with yellowish and purple-grey ground. Av. size, $3 \cdot 02 \times 2 \cdot 33$ in. Laying begins March-April. One brood.

\section{(1) Family: Buteonidae. (b) Subfamily: Buteonina-Buzzards}

152. Buzzard [Buteo buteo buteo (Linnæus); Buteo vulgaris Leach]. More or less stationary in the wilder and hillier districts of Great Britain. Irregular visitor elsewhere.

Bird. Length 21-23 in., the female being the larger. Beak hooked. Coloration variable, but recognised by the general brown hue. There is a varying amount of white on the breast, which may be either barred or striated with brown. Tail barred dusky. Beak hooked, legs yellow and scaled, the latter distinguishing this species from the rarer roughlegged-buzzard, which has the legs feathered to the toes, the base of the tail and tail-coverts white, and a creamy-white head and neck streaked brown.

Nest. Cliffs, rarely trees now. Mass of sticks and other rough material lined with softer material such as grass, fresh leaves, \&c.

Eggs. Usually 2-3. Whitish, more or less blotched with varying shades of red-brown or black-brown, and underlying violet; also bluish-white unmarked. Av. size, $2.15 \times 1.72$ in. Laying begins in April. 

(1) Family: Buteonidce.
(c) Subfamily: Accipitrince-

Sparrow-hawks

153. Sparrow-hawk [Accipiter nisus nisus (Linnæus)]. Stationary in woodland districts. Scarce in N. Scotland. Winter visitor on the $\mathrm{E}$. coast.

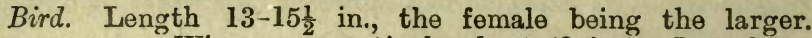

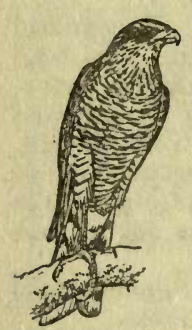

Fig. 89.

Wing comparatively short $(8$ in.). Legs long. Bill hooked. The male has the upper-parts slate-grey, the tail brownish with dusky bars. Under-parts mostly whitish or pale buff closely barred with dark brown and rufous, or rufous only, and on the forebreast and flank tipped with rufous. A chestnut tinge on the lower sides of the head. The female has the upperparts browner. The lower sides of the head are paler than in the case of the male, and streaked brown. The under-parts whitish, mostly barred with umber-brown. The young are like the female, but margined rufous on the upper-parts.

Nest. Usually built of twigs, bark, and some softer material on top of an old nest of crow, wood-pigeon, or magpie.

Eggs. Usually 4-6. Usually bluish-white, sometimes blotched with rich chocolate-brown, sometimes with paler reddish-brown or purplish. Av. size, $1.52 \times 1.26$ in. Laying begins April-May. One brood.

\section{(2) Family: Falconidae}

154. Peregrine-falcon [Falco pergrinus peregrinus Tunstall]. Resident. Chiefly frequents hilly districts and

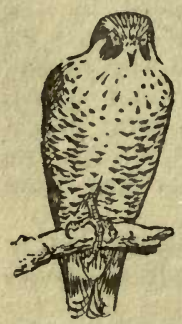

Fig. 90. sea cliffs.

Bird. Length 15-18 in., the female being the larger. Wings comparatively long (14-in.) and pointed. Legs short. Cheeks blackish. Beak hooked. Upper-parts slate-blue, spotted and barred with black. Tail barred dusky, tipped white. Under-parts buffish or rufouswhite, more or less closely barred with black. Logs and feet yellow, unfeathered, and reticulated. Young birds have the upper-parts dusky brown, margined buff or rufous, and the under-parts striped longitudinally black, not barred.

Nest. Usually on the ledge of a cliff face. Sometimes on the ground. A scrape, unlined. 
Eggs. Usually 3-4. Whitish usually nearly or wholly hidden by shades of beautiful tawny pink, orange to brownish-red and purplish-brown. Av. size, 2.01 × 1.59 in. Laying begins usually in April. One brood.

155. Merlin [Falco regulus regulus Pallas; Falco cesalon Tunstall]. Breeds on the hills and moorlands of Wales, N. England, Scotland, and Ireland; possibly Exmoor. Found on lower ground and coasts in autumn.

Bird. Length 11-12 in., the female the larger. Recognised by its relatively small size. Bill hooked. The male has the upper parts bluish with black shaft streaks, except the nape, which is rufous. Tail grey-blue barred, dusky and tipped white. Under-parts whitish, tinged rufous and striated black. Legs yellow. Female, upper-parts dark brown. Tail the same, barred and tipped white. Nape, cheeks, and under-parts whitish striped with dark brown. The young like female, but with pale rufous margins on upper-parts.

Nest. Usually a scrape in the ground among heather with scanty lining. Occasionally in old nests in trees and on cliff ledges.

Eggs. Usually 4-5. Heavily mottled with shades of reddish or purplish-brown, obscuring the ground colour. Av. size, $1.55 \times 1.23$ in. Laying begins usually in May. One brood.

156. Kestrel (wind-hover) [Falco tinnunculus tinnunculus Linnæus]. Resident generally where not persecuted, but scarce N. Scotland and Ireland.

Bird. Length 13-14 in., the female being somewhat larger. Bill hooked. Easily distinguished from the sparrow-hawk by its habit of hovering, its relatively long wings $\left(9 \frac{1}{2}-10 \mathrm{in}\right.$.), the fact that its tawny rust-coloured under-parts are streaked with black longitudinally and not barred, and that the dominating colour of the upper-parts is chestnut-red. Legs yellow and unfeathered. The sexes differ in

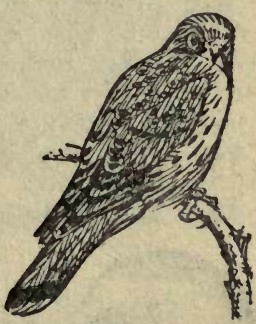

Fig. 91. the coloration of the upper-parts. The male has only the mantle and wing-coverts chestnut-red, with black spots. The top of the head, the rump and the tail are slate-blue, the tail with a broad terminal black band, tipped white. Wing quills dusky. The female has the whole upper-parts, including the tail, dull chestnut-red, with black bars. Young: like the female, but paler.

Nest. Place various : ledges of cliffs and quarries, ruins, on old nests in trees, rarely on the ground. No material. 
Eggs. Usually 4-6. Yellowish-white, being sometimes blotched, sometimes wholly concealed by shades varying from reddish to blackish-brown, and from pale to reddish-yellow. Rarely purplish underlying marks. Av. size, 1.52 1.20 in. Laying begins April-May. One brood

\section{ORDER : ANSERIFORMES. SUB-ORDER : ANSERES}

Family: Anatidae. (a) Subfamily, Anserina-Geese

157. Greglag-goose [Anser anser (Linnæus); Anser cinereus Meyer]. Resident. Breeds N. Scotland. Elsewhere winter visitor or bird of passage.

Bird. Length 34 in. Distinguished from two of the other and rarer Grey Geese (bean-goose, pinkfooted-goose) by the white tip or nail to the bill, and from the third, the white-frontedgoose, which has also a white nail, by having only a little or no white feathering round the base of the bill instead of the conspicuous white patch on the face, which gives the latter species its name. Beak, except tip, and legs pink fleshcoloured. Plumage mostly greyish-brown, lighter on the under-parts, with paler margins on the back and scapulars, and dusky bars on the under-parts. Rump and wing-coverts bluish-grey. Belly dull white. White tip to tail.

Nest. Usually in heather not far from water ; often on a small islet; also in coarse marsh herbage. A scrape lined with heather, rushes, grasses, \&c., with an inner lining of the bird's feathers and down.

Eggs. Usually 4-6. Till stained they are dull yellowishwhite. Av. size, $3.43 \times 2.3$ in. Laying begins mid to end April. One brood.

158. Barnacle-goose [Branta leucopsis (Bechstein); Bernicla leucopsis (Bechstein)]. A winter visitor,

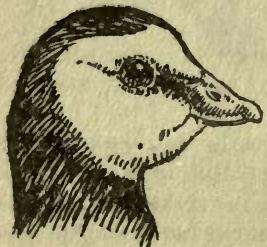

Fig. 92. chiefly to our western coasts, especially the Solway. Bird of passage.

Bird. Length 27 in. Recognised by the white face and throat enclosed by the surrounding glossy black of the crown, neck, and upper breast. Lores black. Mantle and wing-coverts lavendergrey with dark edgings, these being rimmed white. Beak, legs, tail, wing quills black. Breast and flanks whitish, the latter barred grey. Tail-coverts and belly white. The young has the white of the head tinged brown or dusky.

159. Brent-goose [Branta bernicla bernicla (L.); Bernicla 
brenta (Pallas)]. Winter visitor, often in large flocks, chiefly on our east coasts. Bird of passage.

Bird. Length 22 in. Therefore smaller than the barnacle, from which it may be distinguished by the black of the head, neck, and upper breast, relieved only by a patch of white on the neck; by the dusky brown of the mantle, and brownish-grey of the lower and mid-breast. Beak, legs, wing, and tail quills black. Tail-coverts and belly white. The young lack the white neck patch, and the forebreast is grey, not black.

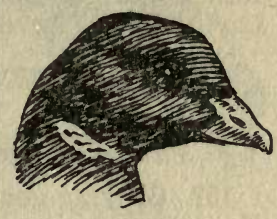

Fig. 93.

\section{Family: Anatidce. (b) Subfamily: Cygnina-Swans}

160. Mute-swan [Cygnus olor (Gmelin)]. Semi-domesticated, resident and stationary species.

Bird. Length 60 in. This familiar tenant on our lakes and rivers may be distinguished from its two wild relatives, the whooper (60 in.) and the smaller Bewick's swan (50 in.) by its reddish beak and black "berry" at the base thereof. Both the whooper and Bewick have the bill yellow on the basal part and black on the tip part, but in the whooper a tongue of the yellow extends forward on each side under and beyond the nostrils. Plumage white. The young swan or cygnet is dusky or brownish-grey.

Nest. Usually near the water edge. A mass of aquatic plants, rushes, grasses, \&c.

Eggs. Usually 5-12. Greenish-white to greenish. Av. size $4.44 \times 2.89$ in. Laying usually begins in April. One brood.

\section{Family: Anatidoe. (c) Subfamily: Anatino-Shelduck and} Surface-water Ducks

161. Common-shelduck [Tadorna tadorna (Linnæus); Tadorna cornuta (S. G. Gmelin)]. Resident on flat coasts and estuaries. Breeds inland in parts.

Bird. Length 25 in. Distinguished by its large size and the boldly marked contrast of its plumage, which is white with greenish-black on the head and neck, with a broad chestnut band round the forepart of the body, a dark band down the middle of the white breast and black on the scapulars and primaries. Tail tipped black. Speculum or wing-spot, chestnut-red and steel-blue. Beak red with a basal knob. The female lacks the basal knob. The young lack the chestnut band and black breast-stripe. 
Nest. Usually near the sea, in holes, some feet long, either

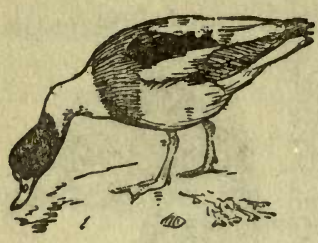

Fig. 94. of a rabbit or burrowed by the bird. Occasionally some distance from the sea. Sometimes in holes among rocks or under bushes. Material: tho ducks' down and feathers mixed with grasses, moss, \&c. Many pairs may nest in close proximity. ।

Eggs. Usually 7-12. Creamywhite. Av. size, $2.57 \times 1.84$ in. Laying begins usually in May. One brood.

162. Mallard or wild-duck [Anas platyrhyncha platyrhyncha Linnæus; Anas boscas Linnæus]. Resident and generally distributed both near salt and fresh water.

Bird. Length 23 in. Recognised by the glossy steel-blue speculum or wing-spot which is margined laterally with white and black. The drake-except from mid-June to midSeptember-has the head and neck glossy green, with a white ring round the neck. The upcurled middle tail-feathers, the rump and tail-coverts are glossy black-green. Back brownish. Scapulars, lower breast and flanks greyish-white pencilled with fine grey wavy parallel lines or vermiculations. Forebreast a dark chestnut. From mid-June to mid-Sept. the drake assumes the "eclipse" plumage which resembles that of the duck, but with a more uniform coloration on the upper-parts. The duck is dark brown marked buff, and has not the middle tail-feathers upcurled.

Nest. On the ground, usually near water, and usually in cover of some sort, rushes, long grass, tangled briars and herbage, hedges and the like. Sometimes away from water. Occasionally in trees, faggots, \&c. Material: dry grass, moss and other material, lined with the bird's down.

Eggs. Usually 8-14. Greenish to buffish-grey. Occasionally with a blue tint. Av. size, $2.21 \times 1.61$ in. Laying begins usually March-April, sometimes earlier and later. One brood.

163. Shoveler [Spatula clypeata (Linnæus)]. Resident, but local. Scarce in Wales. Frequents usually fresh water.

Bird. Length 20 in. Recognised by the large duskycoloured spatulate beak (see Fig. 95), by the speculum or wingspot, which is glossy green (duller in the female) bordered in front with a broad and behind with a narrow white stripe and by the wing-coverts, blue in the drake, grey-blue in the duck, in both conspicuous. The drake has the head and neck dark glossy green, followed on the forebreast by white continued upwards round the neck and on to the scapulars. 
The rest of the under-parts chestnut followed by white, with glossy blackish-green tail-coverts. Back dusky brown. In "eclipse" (about July-October) the drake has the head and neck much like the female, and is duller on the under-parts; but wings as in breeding plumage. The female has the speculum as the male, the wing-coverts grey-blue. Mantle dark brown with paler margins. Under-parts and head mostly pale brown with dusky brown streaks on breast and flanks, and

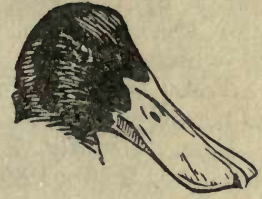

Fig. 95 . finer streaks on the head. The young much like the drake in "eclipse."

Nest. Place : various-meadow, moorland, or marsh, usually but not always near water; a depression in grass, heather, rushes, \&c. Material : grasses, sedges, \&c., lined later with the duck's down.

Eggs. Usually 8-12. Greenish or buffish-grey. Av. size, $2.05 \times 1.45$ in. Laying begins usually April-May. One brood.

164. Pintail [Dafila acuta (Linnæus)]. Breeds in Scotland, but local. More numerous as a winter visitor and bird of passage to our coasts, and, less frequently, inland waters.

Bird. Length 26-29 in., the latter figure being mostly accounted for by the length (sometimes $8 \frac{1}{2}$ in.) of the central tapering feathers in the drake. Speculum of wing patch in both sexes is bronze olive-green, margined in front with bright chestnut, behind with black edged white, and duller in the duck. The drake is recognised by the long

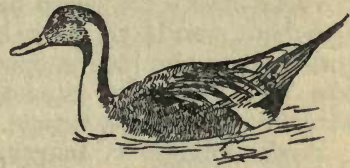

Fig. 96. central brownish-black pin tail-feathers; the brown head, throat, and upper neck, the latter cut on each side by a white stripe which broadens as it descends to join the white of the lower neck, breast, and abdomen. Flanks and back delicately patterned with fine close-set wavy parallel lines or vermiculations of grey on whitish. Inner secondaries much prolonged and coloured black with brownish-tinted margins. Upper and under tail-coverts black with an adjoining buff patch. In "eclipse," about July-October, the drake becomes much like the duck, but may be distinguished by the grey vermiculations, and the wavy bars of white on the scapulars and back, the latter in the duck being greyish covered with more strongly marked irregular crescents of buff and dark brown. Her scapulars are dusky brown barred rufous. Flanks as back, but paler. Under-parts whitish 
marked faintly with rufous-brown. Head tinged chestnut with fine brown markings. May be distinguished from other ducks by the speculum and slender neck. The young are like the male in "eclipse," but have the speculum dull brownish-grey.

Nest. On the ground, in grass or other herbage. Material: as preceding species.

Eggs. Usually 7-10. Shades of buff or yellowish-green. Av. size, $2.16 \times 1.52$ in. Laying begins in early May. One brood.

165. Teal [Nettion crecca crecca (Linnæus)]. Resident in most parts. Prefers fresh water.

Bird. Length $14 \frac{1}{2}$ in. Both sexes may be recognised by the relatively small size, and by the speculum or wing patch, which is half glossy black, half glossy green, bounded on either side by buff, or in front by rufous. Beak black. The drake has the head and neck chestnut, with a band of glossy bluish-green proceeding from the eye backwards, the same bordered above and below with a buff line which is continued from the front of the eye to the bill. Mantle and flanks finely pencilled grey and white, except the hinder scapulars, which are elongated to form a band of black and white. Breast white, spotted black. Belly white. Rump and both tailcoverts dusky brown to black. The male, in "eclipse" (JulyOctober), tends to resemble the female, but may be distinguished by the larger speculum and the fine buff barrings on the mantle. The general hue of the duck is golden-buff streaked with dark brown.

Nest. On moor, marsh, and meadow, usually near water. On the ground in heather, rushes, grass, \&c. Material: as preceding species.

Eggs. Usually 8-16. Creamy-white with a greenish tinge. Small. Av. size, $1.77 \times 1.29$ in. Laying begins April-May. One brood.

166. Wigeon [Mareca penelope (Linnæus)]. Common winter visitor and bird of passage to our shores ; also inland waters. Breeds in Scotland, and exceptionally in N. England and Wales.

Bird. Length $18 \frac{1}{2}$ in. Recognised by the comparatively small lead-blue bill, tipped black, and by the speculum or wing patch. This in the drake is glossy green banded on either side with velvet-black, broad behind, narrow in front, the latter dividing the green from the conspicuous white on the wing-coverts. In the female the speculum is dusky grey and white. The drake has the head chestnut sprinkled with green, crown buff. The back and flanks finely pencilled with 
grey and white. Three of the secondaries on each side are black, edged white. Forebreast greyish-pink. Rest of breast and belly white. Upper and under tail-coverts mostly black. Wing and tail quills dusky brown. In "eclipse" plumage (July-October) the male is not unlike the female, but may be distinguished by the speculum and the rufous ground of the head and mantle, these parts being dusky brown with broad rufous-buff edgings in the duck. The latter has the breast pale chestnut-brown, grey edgings on the brown coverts. Belly greyish-white.

Nest. On moor and marsh, usually not far from lake or pond. On the ground among heather, rushes, \&c. Material: as the preceding.

Eggs. Usually 6-10. Creamy-white. Av. size, $2.16 \times 1.52$ in. Laying begins April-May. One brood.

\section{Family: Anatidoe. (d) Subfamily: Fuligulince-}

Diving-ducks

167. Pochard, redheaded-pochard [Nyroca ferina ferina (Linnæus); Fuligula ferina (Linnæus)]. Chiefly a winter visitor and bird of passage. More often on fresh than salt water. Breeds in Scotland and parts of England, chiefly E.

Bird. Length 19 in. Recognised by the ash-grey speculum or wing patch, and the broad lobe of the hind toe. The drake has the head and neck chestnut-red. Iris red. Beak black with grey on the middle of the upper mandible. The upper breast is black with chestnut tinge, which colour forms a band round the base of the neck and broadens out on the upper back. Rump, upper and under tail-coverts are black. Mantle and

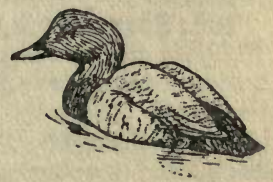

Fig. 97. under-parts whitish, pencilled with fine grey wavy lines. In "eclipse" (July-October) the head and neck are browner, and the breast a dark pencilled grey. The duck has the head mostly dull chestnut-brown, with some white on the sides. Back dark brown mixed with greyish. Wing-coverts pencilled finely dark grey on grey. Flanks dusky brown, rest of under-parts brownish-white. Young birds resemble the duck, but are darker beneath.

Nest. On marshy ground in flags, rushes, and other aquatic plants. It is composed of dead flags, \&c., the duck's down being added later.

Eggs. Usually 6-11. Greenish-grey to greenish-brown. 
Av. size, $2.42 \times 1.72$ in. Laying begins usually April-May. One brood.

168. Tufted-duck [Nyroca fuligula (Linnæus); Fuligula cristata (Leach)]. Winter visitor and bird of passage to our canals and inland waters; less often on salt water. Breeds Scotland, England, Ireland, and Anglesey.

Bird. Length 17 in. Recognised by the erest, which is smaller in the female, and by the black

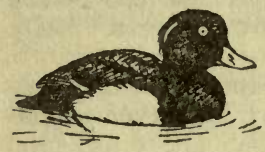

Fig. 98. (male) or dusky brown (female) head, neck, upper-parts, and upper breast; these colours contrasting, in the male, with the white on the lower breast, belly, and flanks which, in the female, are brown to greyish or whitish-brown. The drake has a purple gloss on the head. Both sexes have the beak greyish with a black tip, and the wing speculum white. The male, in "eclipse" (July-October), has the flanks more or less pencilled finely with black ; he is otherwise like the female. Young birds lack the crest and have more or less white on the face.

Nest. Usually near water, among rushes, grass, heather, under bushes. Material : as preceding.

Eggs. Usually 8-12. Olive-brown, greenish-olive, or brownishyellow, "while the shape is somewhat characteristic, many eggs being elongated" (Jourdain). Av. size, 2.32 ×1.61 in. Laying begins in May-June. One brood.

169. Scaup-duck, scaup [Nyroca marila marila (Linnæus); Fuligula marila (Linnæus)]. Winter visitor and bird of passage to our estuaries and low shores. Breeds exceptionally in Scotland.

Bird. Length 19 in. The drake has the head, neck, upper back, and forebreast black with green or purple gloss. The rest of the back, the scapulars, and upper wing-coverts pencilled white and grey. The flanks and the under-parts from the forebreast to the under tail-coverts are white. Upper and lower tail-coverts black. Speculum or wing patch white with a greenish-black border. The drake, in "eclipse" (July-October), is like the duck, but has the head and upper breast much darker. The duck has a conspicuous band of white round the base of the bill. Head, neck, and forebreast rufous-brown, with more or less white on the side of the head. Mantle pencilled grey on a brownish ground. Same for flanks. Belly white. Speculum as male. The young much like the duck.

170. Goldeneye [Clangula clangula (Linnæus); Clangula glaucion (Linnæus)]. Winter visitor and bird of passage to our coasts and inland waters. 
Bird. Length $18 \frac{1}{2}$ in. The drake is recognised by the round white spot in front of each eye, conspicuous between the bluish-black beak and the glossy greenish-black of the head; by the large white areas on the scapulars, the wing-coverts and secondaries, the white under-parts and black back. A short crest. The male in "eclipse" (July-October) resembles the female, but

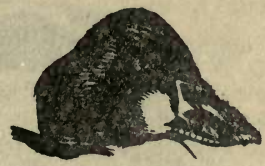

Fig. 99. is readily distinguished by the remains of white on the head. The duck has the head umber-brown, without the white spot, the back, breast, and flanks greyishbrown or greyish, mixed with darker grey. Rest of underparts white. Less white on the wings than the drake, and this divided by two black stripes instead of one, as in his case. The young resemble the female.

171. Longtailed-duck [Harelda hyemalis (Linnæus); Harelda glacialis (Linnæus)]. Winter visitor, chiefly to our $\mathbf{E}$. coasts, more rarely inland waters. Appears to breed occasionally on the Shetlands and Orkneys.

Bird. Length 22-26 in. The sexes differ conspicuously. The drake in winter and summer has the central tail-feathers long, slender, and black, the outer and shorter being white. Beak blackish, middle portion rose-colour (when fresh, according to $\mathrm{H}$. Saunders). In winter the head and neck are more or less white or greyish with a large patch of dark brown shading below into paler

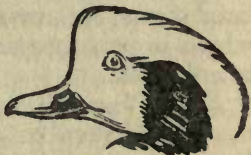

Fig. 100. brown (see Fig. 100). The back to the tail, the breast, wing-coverts, and quills dusky brown or blackish. The long scapulars, inner secondaries, belly, and flanks mostly white. In the summer plumage, which is completed in May, the cheeks are whitish or buffish-white, the rest of the upper-parts and the breast blackish-brown, with rufous margins on the back and scapulars, the latter not long and white as in winter. Flanks and belly white. The female lacks the long tail-feathers and the long white scapulars. All the upperparts are brownish, except a ring round the base of the neck and the sides of the head, which are greyish-white. Forebreast rust brown, rest of under-parts pale brown. The young are much like the duck.

172. Common-eider [Somateria mollissima mollissima (Linnæus)]. Breeds on our coasts and marine islands from Northumberland and Kirkcudbright northwards ; also winter visitor to same. Elsewhere occasional. Has bred Ireland. 
Bird. Length 23 in. Sexes differ markedly, but in both the face feathers are carried

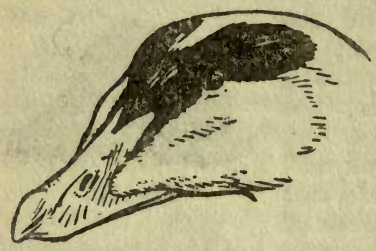

Fig. 101. forward some distance along each side of the beak. The drake has the upper back, wingcoverts, and scapulars white. Longer secondaries buffish-white. Head and neck white except for the pale sea-green on each side of the nape, and the black patch on the crown (see Fig. 101). Primaries, shorter secondaries, rump, and tail brownish-black, with a white patch on each side of the rump. Under-parts black, except the rosy-buff of the breast. In the "eclipse" dress (June Oct.) the plumage is generally rusty brown mixed white. Duck : mantle dark brown broadly edged rufous. Under-parts brown finely barred grey or pale brown. Two white bars on the wing. The young are like the female, with less white on the wings.

Nest. Near the sea, usually on islands. On the ground in rough herbage, among rocks, or under a boulder. Material: dead grass, \&c., or sea-weed, lined later with the famous down, which is pale greyish-brown with light centres. Species breed in colonies.

Eggs. Variable in numbers, 4-11 or more. Colour ranges from shades of olive to greenish-grey or bluish-green. Smooth and large. Av. size, 3.06 × 2.05 in. Laying begins May. One brood.

173. Scoter, black-duck [Oidemia nigra nigra (Linnæus)]. Winter visitor and bird of passage to our seas. Also breeds north Scotland, rarely Ireland.

Bird. Length 20 in. Recognised by the wholly black coloration of the drake, and the mostly sooty or rusty brown coloration of the duck. Legs and toes dusky. The male has a black knob at the base of the bill, the latter being black with a conspicuous orange-yellow patch on the middle part of the upper mandible. The knob is absent or nearly so in the female; also the orange-yellow. She may further be distinguished by the dusky grey cheeks. Young birds may be recognised by the whitish under-parts vaguely mottled brown. Among a flock of common-scoters may be seen the rarer velvet-scoter, easily distinguished by the white bar across the wing, smaller in the female and young.

Nest. Usually in swampy moorland, among heather; also on islets in lakes, usually near water but not always. Material: heather, rushes, \&c., with a lining of down. 
Eggs. Usually 5-8. Pale buff to warm cream. Rather poirted and oval in shape; large. Av. size, $2.57 \times 1.75$ in. Laying begins in June. One brood.

Family: Anatidae. (e) Subfamily: Mergina-Sawbill-ducks

174. Goosander [Mergus merganser merganser (Linnæus)]. Breeds in N. Scottish mainland, and occasionally W. Isles (Sumner Isles). Winter visitor and bird of passage, chiefly to our $\mathbf{E}$ coasts. Salt and freshwater species.

Birl. Length 26 in. Like the other sawbills, the goosander has a straight, slender bill, hooked, and with the edges of both nandibles cut with saw-like teeth directed backward. The drake has the head and upper part of neck glossy blackgreen. Nape feathers somewhat elongated, but no conspicuous crest like the merganser. Mantle mostly black. The outside scapılars, wing-coverts, secondaries, and under-parts mostly whit with salmon-pink tinge on the under-parts. Legs and beak red. In "eclipse" (July-October) the drake is like the female, but has darker upper-parts and a more or less complete black ring round the neck between the chestnut-brown and whitish areas. The duck has the head and neck chestnutred, with a white throat. Upper-parts mostly slate-grey. Wiite on the major coverts and inner secondaries. Underparts white with more or less rosy tint, except the flanks, wich are grey or greyish-buff. Thick, bushy crest. Beak and lers red. The young female resembles fairly closely the duck, the male being more like the adult male in "eclipse."

Nest. On islets in lochs, near streams or rivers ; built in hcllow trees, holes in a bank, hillside, or among boulders; occasionally in a hollow in the ground or under a thick bush. Naterial : dry. grass, rootlets, \&c., and down. In a tree-hole, decayed wood.

Eggs. Usually 7-12. Creamy or yellowish. Av. size, 2*69x 1.85 in. Laying begins in April. One brood.

175. Redbreasted-merganser [Mergus serrator (Linnæus)]. Breeds $\mathrm{N}$. and mid-Scotland and in Ireland. Also winter visitor and bird of passage. More marine than the goosander.

Bird. See No. 174. Length 24 in., therefore smaller than the goosander, from which it may be distinguished in both sexes by the

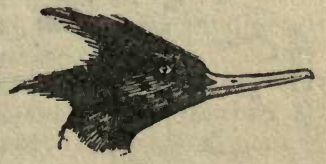

Fig. 102. reddish throat. The drake has a blackish-green head with a double crest of long slender feathers (see Fig. 102). Iris red. A white ring round the neck. Upper breast reddish-brown 
with darker streaks. Sides of upper breast at base of neck black. Scapulars black margined white. Upper wing-coverts white margined black, making conspicuous white triangular patches. Wing-coverts and secondaries mostly white, making a broad white band on each side of the body when the wings are closed, cut transversely by two black bars. Underbreast and belly white tinted rosy. Flanks pencilled dark grey or whitish. Beak and legs red. In "eclipse" (from about July-October) the drake is not unlike the duck, but has the upper-parts darker and the wing-coverts white. The duck has the head, neck, and throat chestnut mixed brown. The throat distinguishes her from the duck goosander, which has it white. Upper-parts mostly dusky brown with paler margins. Wings barred white. Under-parts whitish streaked with brownish-grey on the breast. Crest shorter than drake's. Legs and beak reddish.

Nest. Usually near water, on islets in lakes, or lake shores. Built on the ground in heather or other rough herlage, under bushes or projecting rocks, in the hollow of a kank, wall, or cliff ; also in rabbit-holes. Not in tree-hollows, so far as known. Material: dead bracken, grass, or other material, lined later with the duck's down.

Eggs. Usually 7-12. Usually greyish-brown or olive-grey, occasionally light greyish-buff. Av. size, $2.52 \times 1.78 \mathrm{in}$. Laying begins in May-June. One brood.

\section{ORDER: CICONIIFORMES. (1) SUBORDER ARDE在}

\section{Family: Ardeidoc-Herons and Bitterns}

176. Common-heron [Ardea cinerea (Linnæus)]. Residert and generally distributed. Somewhat local.

Bird. Length 36 in. Recognised by its size, the long

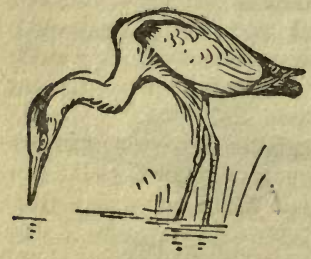

Fig. 103. straight yellow beak, long legs, the general grey and white plumage. In flight the broad rounded slow flapping wings and the neck curved back, so that the head rests between the shoulders, aid recognition. The male has the upper-parts from the base of the neck to the tip of the tail lightish or French grey. The wing quills dark slate-blue.

The head and neck are white with bluish-black elongated plumes behind the eyes, forming a pendant crest, and bluish-black lines of spots down the front 


\section{CORMORANTS}

of the neck. Under-parts white, with elongated feathers hanging from the base of the neck. The female resembles the male, but is smaller. The young lack the crest and the pendant breast feathers.

Nest. Usually in trees, near the top; also on the ground or low bushes, even in reed-beds. A large structure of sticks, lined with twigs, grass, \&c. The species usually nests in colonies.

Eggs. Usually 4-5. Light blue-green without gloss. Av. size, $2.36 \times 1.69$ in. Laying begins usually in February. One, probably sometimes two broods.

\section{ORDER : CICONIIFORMES. (2) SUBORDER : STEGANOPODES}

(1) Family: Phalacrocoracida-Cormorants

177. Cormorant, great or black-cormorant [Phalacrocorax carbo carbo (Linnæus)]. Resident on most of our rocky coasts. Also breeds on inland waters.

Bird. Length about 3 feet. Like the next two species it has the four toes webbed; and, like the shag, it has a straight, hooked bill and comparatively short black legs set well back, but is much larger in size (shag, $2 \mathrm{ft}$. 2 in.), and has bluish-black under-parts, the shag being mostly greenish or greenish-black, and fourteen tail-feathers, the smaller species having twelve. In breeding dress it has a crest of scattered hair-like white plumes, a continuous white band passing round the throat upward to the back of each eye, and a white patch on the thigh. Shape as shag (Fig. 104). The young are generally brownish, with more or less white on the breast and belly, and a brown iris instead of green.

Nest. On rocky islets or ledges of cliffs by the sea; and when inland usually on islands in lakes, in which case it may be built in trees instead of on the ground. Material : sticks and rough material with finer lining, grasses, feathers, \&c., when in trees ; sea-weed mostly when on rocks or ledges by the sea. The species breeds in colonies.

Eggs. Usually 3-5. Blue, mostly covered with a chalky white deposit, soon stained. Av. size, $2.52 \times 1.55$ in. Laying begins April-May. One, probably two broods.

178. Shag, green-cormorant [Phalacrocorax graculus graculus (Linnæus)]. Breeds on our rocky coasts, except S.E. and E. England to Northumberland. Scarce E. Scotland. Rare inland. Local movements in winter.

Bird. See preceding species. In breeding plumage both sexes have a curved crest on the crown. Iris green. The young may be distinguished from the young of the cormorant by the twelve tail-feathers. 
Nest. Usually on ledges in sea-caves, sometimes on a cliff ledge or in recesses among boulders by the sea; generally,

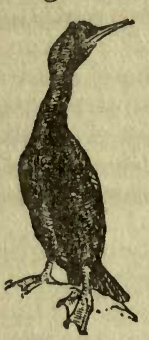

Fig. 104. therefore, unlike the cormorant's, under cover. Material: sea-weed and coarse herbage. The species breeds in colonies.

Eggs. Usually 3-5. Like cormorant's, but smaller. Av. size, $2.51 \times 1.51$ in. Laying begins March-April. Two broods.

\section{(2) Family: Sulido-Gannets}

179. Gannet or Solan-goose [Sula bassana (Linnæus)]. Resident. Strictly marine species. Breeds in large colonies on rocky islands at various points round our coasts.

Bird. Length 33 in. (See No. 177.) Bill strong, straight, not hooked, and of a pale lead-blue with deeper slate coloured longitudinal lines. Tail graduated to a point, the central feathers the longest. Wings long and rather narrow. Plumage white, save the wing quills, which are dark brown, not black as usually stated. In breeding dress there is a buff tinge on the head and neck. The fledgling blackish-slate, spotted white. Immature till the fifth year, and recognised by the dark brown, chiefly on the back, wings, and tail, which colour diminishes season by season till at maturity reduced to the brown of the wing quills.

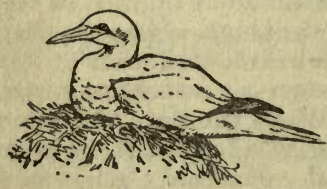

Fig. 105.

Nest. Generally on the ledges of the precipitous sides of sea-washed isles, such as the Bass Rock, Ailsa Craig (Scotland), Bull Rock and Little Skellig (Ireland). Material: sea-weed, grasses from the isle top, and any material from the surface of the sea.

Egg. One. Blue, covered or nearly so with a white chalky deposit which soon becomes dirty and yellow stained. Av. size, $3.06 \times 1.96$ in. Laying begins March-May. One brood.

\section{ORDER: PROCELLARIIFORMES. SUBORDER: TUBINARES}

\section{Family : Procellariido-Petrels}

180. Manx-shearwater [Puffinus puffinus puffinus (Brünnich); Puffinus anglorum (Temminck)]. Seen on all our coasts, but breeds only on the west, the Irish coasts, Orkneys, and Shetlands.

Bird. Length 15 in. Beak long, slender, with hooked tip, and dusky brown external tubular nostrils (see No. 182, Fig. 106). 
Wings long and pointed. Feet webbed. Tail rounded. Upperparts sooty-black. This colour extends down on each side of the posterior end of the body, except for which and brown mottling on the side of the neck, the under-parts are white. The rarer great-shearwater, which is to be seen in autumn, may be distinguished by its larger size (19 in.) and brownish upper-parts.

Nest. In a burrow made in the soil, on the slopes of a seacliff, or island, sometimes in rabbit holes or in the recesses of rocks and under stones. Material : chiefly grass; sometimes no material. The species breeds in colonies.

Egg. One. White. Av. size, $2.39 \times 1.67$ in. Laying begins May. One brood.

181. Fulmar, mollymauk [Fulmarus glacialis glacialis (Linnæus)]. Seen off all our coasts, but breeds only on the west and northern Scottish coasts and islands, and a few places on the Irish coasts.

Bird. Length 19 in., i.e. about the size of the commongull. External tubular nostrils (see Fig. 106). Beak hooked at the tip and mostly yellowish. Feet webbed. Mantle and tail grey. Wing quills mostly dusky. Rest of plumage white or varying shades of grey.

Nest. On the ledges, in the recesses, or in a hollow in the vegetation-covered slopes of sea-cliffs. Occasionally tops of

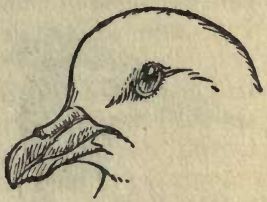

Fig. 106. stacks. Sometimes no material. sometimes a few grasses, \&c., or fragments of stone. Species breeds in colonies.

Egg. One. White, occasionally traces of red spots. Av. size, $2.88 \times 1.95$ in. Laying begins in May. One brood.

182. Storm-petrel [Hydrobates pelagica (Linnæus); Procellaria pelagica Linnæeus]. Seen off all our coasts, chiefly in spring and autumn. Breeds on the islands off our west coasts, from Scilly to Shetlands, and off the Irish coasts. More rarely on E. Scottish coasts.

Bird. Length $6 \frac{1}{2}$ in. Distinguished from all species outside its own suborder (Petrels, Shearwaters, Fulmars, Albatrosses) by the prominent external tubeshaped nostrils, which give the suborder its name Tubinares. Foet webbed. Beak and legs black, the former with hooked tip. Plumage black, except the conspicuous white of the posterior end of

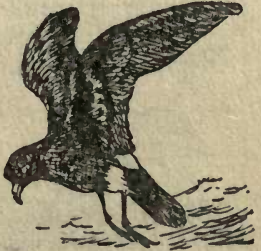

Fig. 107. the body (see figure), and the thin white margins on the major wing-coverts. The rarer Leach's forktailed-petrel re- 
sembles the storm-petrel, but is at once recognised by its larger size ( 8 in.), the markedly forked tail, and the grey on the wing-coverts and secondaries.

Nest. On rocky sea-washed islands, under stones or boulders, in crevices of rocks or ruins, in burrows made by the bird or in those of rabbits. Scrape unlined or lined with a few grasses, \&c.

Egg. One. Chalky-white, more or less zoned with reddishbrown spots round the bigger end. Av. size, $1 \cdot 1 \times 84 \mathrm{in}$. Laying begins end May-June, or later. One brood.

\section{ORDER : COLYMBIFORMES. (1) SUBORDER : PODICEPEDES}

\section{Family: Podicepidida-Grebes}

183. Great crested-grebe [Colymbus cristatus Linnæus ; Podicipes cristatus (Linnæus)]. Breeds on fresh water lakes in most

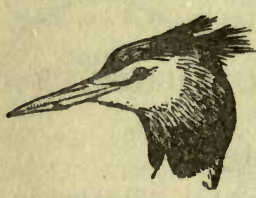

Fig. 108. parts of the British Isles, except north of the Grampians. Local movement to the coasts in winter.

Bird. Length 21 in. The Family has tail almost absent, toes lobed (Fig. 109). Species recognised by the dark brown of the crest, crown, and upper-parts, the chestnut tippet or ruffle with blackish margin, the white secondaries conspicuous in flight, and the white under-parts. Female duller, with smaller crest and tippet. The young are said to show little crest or chestnut colour till the second year.

Nest. In the shallows of lakes, either floating on the surface attached to surrounding reeds or other aquatic plants, or built up from the bottom. Material: a mass of aquatic plants. Eggs usually covered when bird not on.

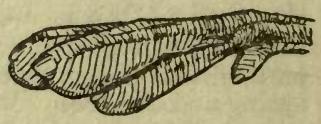

Fig. 109.

Eggs. Usually 4. Chalky-white, pale bluish or greenish-white, but soon stained dirty brownish by con-

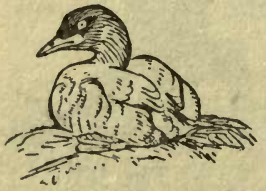

Fig. 110. tact with wet weeds. Av. size, $2 \cdot 20 \times 1 \cdot 44$ in. Laying begins April-May. Broods 1-2.

184. Little-grebe or dabchick [Colymbus ruficollis Pallas; Podicipes fuviatilis (Tunstall)]. Resident. Also found generally distributed on our rivers, lakes, and ponds. Found on the coast in winter. Bird. Length $9 \frac{1}{2}$ in., therefore much smaller than the pre- 
ceding species. Lobed toes (see Fig. 109, No. 183). Tail almost absent. Upper-parts dark brown. Under-parts whitish, except the chestnut throat and sides of the neck, and the dusky flanks and the black chin. The white on the secondaries is limited to the inner webs. Legs dull green. Beak horn colour, with yellowish-green at the gape. Female smaller. After the autumn moult the chin and throat are white, and the chestnut of the sides of the neck fades to buff. Young much like the adult in winter plumage.

Nest. A mass of aquatic plants placed usually among reeds or other water-plants in or by lakes, ponds, and sluggish rivers. Also in the open in shallow water, or near the bank under overhanging branches. Either floating and attached to surrounding plants, or built up from the bottom. Not normally floating free. Eggs usually covered when bird not on.

Eggs. Usually 4-6. Bluish-white, but rapidly stained varying shades of dirty browns or reds. Av. size, $1.48 \times 1.02$ in. Laying usually begins April. Broods probably two.

\section{ORDER : COLYMBIFORMES. (2) SUBORDER : COLYMBI}

\section{Family: Colymbida-Divers}

185. Great northern-diver [Gavia immer (Brünnich); Colymbus glacialis Linnæus]. Winter visitor and bird of passage to our coasts and inland waters, chiefly northern. Occurs also in summer.

Bird. Length 31 in. ; male the larger. Recognised by the black, green, and purple glossed head and neck, broken on the throat and neck by two white bands, marked with close set, parallel, dark downward streaks, which are continued below the green on the white of the lower neck. Mantle glossy black, with conspicuous cross bands of white spots. Under-parts white. Beak black, strong and pointed. Legs mostly greenish-black. Wing quills and tail dark-brown, the latter short and rounded. After the autumn moult the upper-parts,

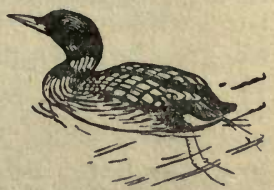

Fig. 111. including the head and nape, are darkish brown with paler margins to the feathers. All under-parts, including throat and breast, white with streaks on the neck. The much rarer blackthroated-diver, though not unlike the present species, may be distinguished at all ages and seasons by the smaller size (27 in.) and the shorter, more slender bill ; and in breeding plumage by the ash-grey crown and nape and the purplish-black throat. 
186. Redthroated-diver [Gavia stellata (Pontoppidan); Colymbus septentrionalis Linnæus]. Breeds in Scotland and Ulster. Winter visitor and bird of passage to all our coasts, also to inland waters.

Bird. Length 24 in., therefore much smaller than the preceding, and easily distinguished in breeding plumage by the chestnut-red throat and the dark brown, instead of black, mantle which is without the conspicuous bands of white spots, being merely flecked with white or buff. Like the rarer blackthroated-diver (No. 187), it has the head and nape ash-grey, but streaked white and black-brown down the hinder top of the head and the nape, these darker streaks continuing down the white neck, sides, and flanks. Under-parts white. After the autumn moult it is distinguished by its smaller size (see No. 187).

Nest. Usually on the margin of a small lake or hill tarn, less often on an islet in the same; a depression in the ground made by the bird, and more or less lined with a few bents, rushes, \&c.

Eggs. Usually 2. From chocolate to olive-brown, sparingly spotted with brownish-black. Av. size, $2.89 \times 1.82$ in. Laying begins in May. One brood.

187. Blackthroated-diver [Gavia arctica (Linnæus); Colymbus arcticus Linnæus]. Breeds Perth and Argyll, north to tho Shetlands. Uncommon winter visitor and bird of passage on our coasts.

Bird. Length $27 \cdot 5$ in. Sexes alike. Distinguished in breeding plumage from both the preceding by the uniform ash-grey of the head and neck, with slate-grey on the crown. Back and wings greenish-black with white spots forming bars. Throat purplish-black. Longitudinal black and white stripes on sides of neck and breast. Flanks black. Rest of underparts white. See Nos. 185-6. After the autumn moult the ash-grey becomes pale brown. Ash-brown without spots on the rest of the upper-parts. Under-parts white, except the brownish-black flanks. The redthroated form also has the under-parts white, but the flanks and upper-parts are slategrey, the latter being mostly spotted or speckled with white. The young blackthroated-diver resembles the adult in winter, but has grey margins on the upper-parts, these being white in the young redthroated-diver.

Nest. Usually on islets in lochs. A depression in the vegetation, sometimes lined with heather, grass, \&c.

Eggs. Usually 2. Olive-brown to olive-green or deep brown sparingly spotted with blackish-brown. Av. size, 3.33 ×2.04 in. Laying begins May. One brood. 


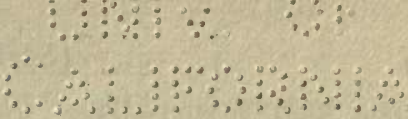

\section{NDE X}

\section{The References are to the Sections}

ARCTIC-SK UA, 117

Arctic-tern, 107

Auks, 100-104

BARNACLE-GOOSE, 158

Barn-owl, 89

Bartailed-god wit, 136

Bearded-tit, 76

Bewick's swan, 160

Blackbacked-gulls, 113

Blackbird, 44

Blackcap, 54

Blackcock, 144

Black-cormorant, 177

Black-duck, 173

Black-guillemot, 102

Blackheaded-gull, 109

Blacktailed-godwit, 136

Blackthroated-diver, 187

Blue-felt, 43

Blueheaded-wagtail, 33

Blue-tit, 73

Bonxie, 116

Brambling, 12

Brent-goose, 159

Brown-linnet, 18

Brown-owl, 92

Bullfinch, 22

Buntings, 23-27

Butcher-bird, 77

Buzzard, 152

Caperdathlie, 143

Carrion-crow, 2

Chaffinch, 11

Chats, $47-48$

Chiffchaff, 58

Chough, 8

Cirl-bunting, 25

Coal-tit, 69-70

Common-gull, 11

Common-sandpiper, 133

Common-snipe, 120

Common-tern, 106

Coot, 142

Cormorants, 177-178

Corn-bunting, 23
Corncrake, 139

Crested-grebe, 183

Crested-tit, 74

Crossbill, 21

Crows, 1-8

Cuckoo, 95

Curlew, 137

Curlew-sandpiper, 131

Cushat, 96

DABCHICK, 184

Dartford-warbler, 56

Daw, redlegged, 8

Dipper, 39

Divers, 185-187

Dotterel, 122

Ducks, 161-175

Dunlin, 129

Dunnock, 65

EAGLES, 151

Eider-duck, 172

FALCONS, 154-156

Fieldfare, 43

Finches, 9-22

Flycatchers, 78-79

French-partridge, 149

Fulmar, 181

GANNET, 179

Garden-warbler, 55

Geese, 157-159

Glaucous-gull, 114

Goatsucker, 88

Godwits, 136

Goldcrest, 57

Golden-eagle, 151

Goldeneye, 170

Golden-plover, 124

Goldfinch, 13

Goosander, 174

Grasshopper-warbler, 64

Great blackbacked-gull, 113

Great crested-grebe, 183

Great northern-diver, 185 Great-plover, 118
Great-skua, 116

Great spotted - woodpecker, 84

Great-tit, 68

Grebes, 183-184

Green-cormorant, 178

Greenfinch, 9

Green-linnet, 9

Green-plover, 126

Green-sandpiper, 134

Greenshank, 135

Green-woodpecker, 83

Greyhen, 144

Greylag-goose, 157

Grey-partridge, 148

Grey-plover, 125

Grey-wagtail, 32

Grouse, 143-146

Guillemot, 101

Gulls, 109-115

HAWFINCH, 10

Hawks, 152-156

Hedge-sparrow, 65

Heron, 176

Herring-gull, 111

Hooded-crow, 3

House-martin, 81

House-sparrow, 19

ICRLAND-GULL, 114

JACKDAW, 5

Jack-snipe, 121

Jay, 7

KENTISH-PLOVER, 123

Kestrel, 156

Kingflsher, 94

Kittiwake, 115

Knot, 131

\section{LANDRAIL, 139}

Lapwing, 126

Larks, 28-29

Laughing-gull, 109

Leach's forktailed-petrel, 182 
Leoiz: Joschbscked-gull, , RAJ LS, $1: 39$ 142 112

Lesser-redpoll, 15

Lesser spotted - wood. pecker, 85

Lesser-whitethroat, 53

Linnet, 18

Little-auk, 103

Little-grebe, 184

Little-owl, 93

Little-tern, 108

Longeared-owl, 90

Longtailed-duck, 171

Longtailed-tit, 67

Magpie, 6

Mallard, 162

Manx-shearwater, 180

Marsh-tit, 71

Marsh-warbler, 62

Martins, 81-82

Mavis, 41

Meadow-pipit, 35

Mealy-redpoll, 16

Merganser, 175

Merlin, 155

Mistle-thrush, 40

Moorhen, 141

Mute-swan, 160

NIGHTHAWK, 88

Nightingale, 51

Nightjar, 88

Norfolk-plover, 118

Nuthatch, 75

OWLS, 89-93

Ox-eye, 68

Oyster-catcher, 127

PARTRIDGIS, 148-149

Peewit, 126

Peregrine-falcon, 154

Petrels, 182

Pheasant, 147

Pied-flycatcher, 79

Pied-wagtail, 30

Pigeons, 96-99

Pintail-duck, 164

Pipits, 34-36

Plovers, 122-126

Pochard, 167

Ptarmigan, 146

Puffin, 104

Purple-sandpiper, 130

QUAIL, 150

Raven, 1

Razorbill, 100

Redbacked-shrike, if

Redbreast, 50

Redbreasted - merganser, 175

Redgrouse, 145

Redlegged-partridge, 149

Redshanks, 135

Redstart, 49

Redthroated-diver, 186

Redwing, 42

Reed-bunting, 26

Reed-warbler, 61

Richardson's skua, 117

Ring-dove, 96

Ringed-dotterel, 123

Ringed-plover, 123

Ring-ouzel, 45

Robin, 50

Rock-dove, 98

Rock-pipit, 36

Rook, 4

Roseate-tern, 106

Roughlegged-buzzard, 152

SANDERIING, 132

Sand-martin, 82

Sandpipers, 129-134

Sand wich-tern, 105

Scaup-duck, 169

Scoter, 173

Screech-owl, 89

Sea-pie, 127

Sedge-warbler, 63

Shag, 178

Shelduck, 161

Shooi, 117

Shorteared-owl, 91

Shoveler, 163

Siskin, 14

Skooi, 116

Skuas, 116-117

Skylark, 28

Snipes, 120-121

Snow-bunting, 27

Solan-goose, 179

Song-thrush, 41

Sparrow-hawk, 153

Spotted-flycatcher, 78

Spotted-woodpecker, 8485

Starling, 66

Stock-dove, 97

Stonechat, 48
Stone-curlew, 118

Storm-petrel, 182

Swallow, 80

Swans, 160

Swift, 87

TAWNY-OWL, 92

Tea], 165

Terns, 105-108

Thick-knee, 118

Throstle, 41

Thrushes, 40-51

Titlark, 35

Tits, 67-74

Tree-creeper, 37

Tree-pipit, 34

Tree-sparrow, 20

Tufted-duck, 168

Turnstone, 128

Turtle-dove, 99

Twite, 17

WAGTAILS, 30-33

Warblers, 52-64

Waterhen, 141

Water-ouzel, 39

Water-rail, 140

Wheatear, 46

Whimbrel, 138

Whinchat, 47

Whitefronted-goose, 157

White-owl, 89

Whitetailed-eagle, 151

Whitethroat, 52

White-wagtail, 31

Whooper, 160

Wigeon, 166

Wild-duck, 162

willow-tit, 72

Willow-warbler, 59

Willow-wren, 59

Wind-hover, 156

Woodcock, 119

Woodlark, 29

Wood-owl, 92

Woodpeckers, $83-85$

Wood-pigeon, 96

Wood-sandpiper, 134

Wood-warbler, 60

Wood-wren, 60

Wren, 38

Wryneck, 86

YELLOW-BUNTING, 24

Yellow-hammer, 24

Yellow-wagtail, 33 
$5 x^{5}+x^{2}+30 x$ 
THIS BOOK IS DUE ON THE LAST DATE STAMPED BELOW

\section{AN INITIAL FINE OF 25 CENTS} WILL BE ASSESSED FOR FAILURE TO RETURN THIS BOOK ON THE DATE DUE. THE PENALTY WILL INCREASE TO 50 CENTS ON THE FOURTH DAY AND TO $\$ 1.00$ ON THE SEVENTH DAY OVERDUE.

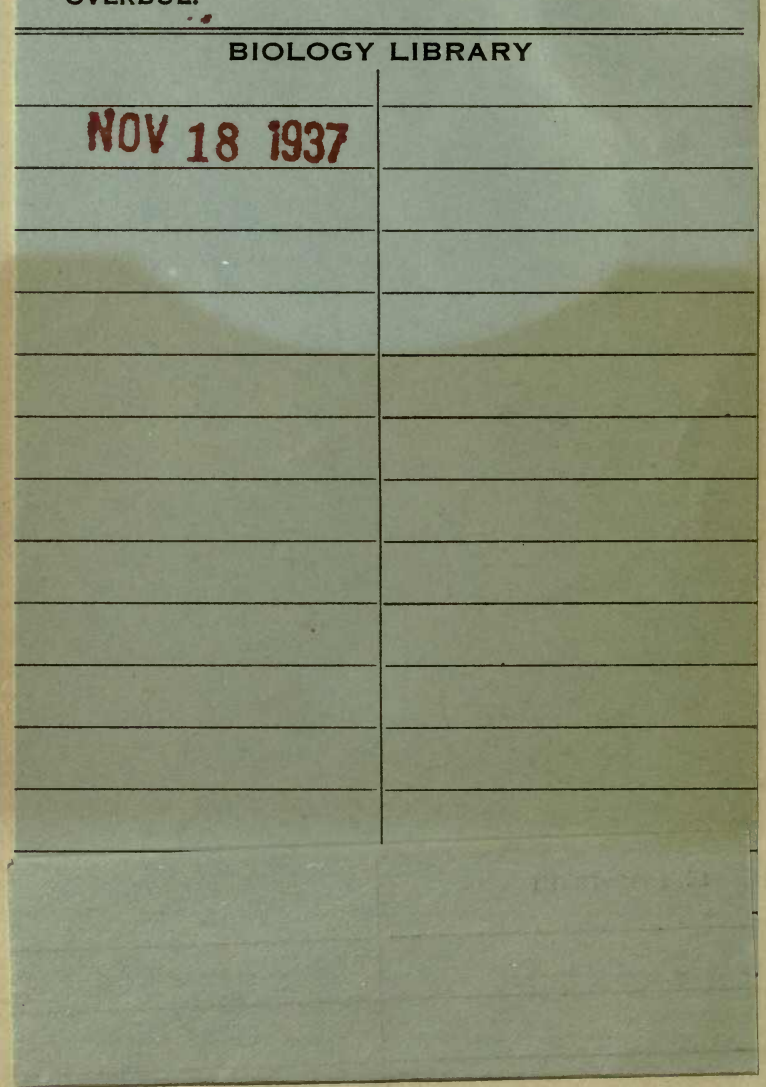


